\title{
USING THE SURVEY OF PLANT CAPACITY TO MEASURE CAPITAL UTILIZATION
}

\author{
by \\ Yuriy Gorodnichenko * \\ UC Berkeley and NBER \\ and \\ Matthew D. Shapiro * \\ University of Michigan and NBER
}

CES 11-19 July, 2011

The research program of the Center for Economic Studies (CES) produces a wide range of economic analyses to improve the statistical programs of the U.S. Census Bureau. Many of these analyses take the form of CES research papers. The papers have not undergone the review accorded Census Bureau publications and no endorsement should be inferred. Any opinions and conclusions expressed herein are those of the author(s) and do not necessarily represent the views of the U.S. Census Bureau. All results have been reviewed to ensure that no confidential information is disclosed. Republication in whole or part must be cleared with the authors.

To obtain information about the series, see www.census.gov/ces or contact Cheryl Grim, Editor, Discussion Papers, U.S. Census Bureau, Center for Economic Studies 2K130B, 4600 Silver Hill Road, Washington, DC 20233, CES.Papers.List@census.gov. 


\begin{abstract}
Most capital in the United States is idle much of the time. By some measures, the average workweek of capital in U.S. manufacturing is as low as 55 hours per 168 hour week. The level and variability of capital utilization has important implications for understanding both the level of production and its cyclical fluctuations. This paper investigates a number of issues relating to aggregation of capital utilization measures from the Survey of Plant Capacity and makes recommendations on expanding and improving the published statistics deriving from the Survey of Plant Capacity. The paper documents a number of facts about properties of capital utilization. First, after growing for decades, capital utilization started to fall in mid 1990s. Second, capital utilization is a useful predictor of changes in capacity utilization and other factors of production. Third, adjustment of productivity measures for variable capital utilization improves statistical and economic properties of these measures. Fourth, the paper constructs weights to aggregate firm level capital utilization rates to industry and economy level, which is the major enhancement to available data.
\end{abstract}

* We thank the staff of the US Census Bureau research data centers at the University of Michigan and University of California, Berkeley for support during our work with the micro level data. We are grateful to Cheryl Grim for comments. Shapiro acknowledges the support of NSF Grant SES 0962219. DISCLAIMER: Any opinions and conclusions expressed herein are those of the author(s) and do not necessarily represent the views of the U.S. Census Bureau. All results have been reviewed to ensure that no confidential information is disclosed. 


\section{Overview}

Most capital in the United States is idle much of the time. By some measures, the average workweek of capital in U.S. manufacturing is as low as 55 hours per 168 hour week. The level and variability of capital utilization has important implications for understanding both the level of production and its cyclical fluctuations. For example, much of variation in output over the business cycle comes from changes in utilization of quasi-fixed factors. Hence, having reliable measures of capital utilization is an important adjunct to other measures of utilization, for example, of labor through measures of average weekly hours. Likewise, productivity varies cyclically because of changes in utilization. Being able to measure capital utilization should allow analysts to better divide observed changes in productivity into its cyclical component and true changes in technology. This decomposition of productivity is important, for example, for guiding monetary policy and for assessing the long-run fiscal position of the government. To complete this non-exhaustive list, note that in deciding how to increase their level of output, firms can either expand capacity or use their current capacity more intensively. Understanding this margin has important implications for, e.g., how investment responds to tax changes. In short, better measurement and understanding of capital utilization can help answer a broad array of questions in economics.

The principal goal of this paper is to construct and present time series for capital utilization for manufacturing and by industry. The key source of information for this exercise is the Survey of Plant Capacity (SPC) conducted by the U.S. Census Bureau. Specifically, we address a number of conceptual and statistical issues related to measuring and aggregating data on capital utilization and its components (number of shifts, capital hours) using the SPC data. This issue of aggregation depends critically on economic forces determining variation in capital utilization across plants and across time. Hence, modeling of the determinants of plants' rates of capital utilization is a critical input into addressing these statistical issues.

We examine the properties of different schemes for weighting these data and make recommendations about what weighing scheme would work best for public release of aggregates based on SPC. This improved information about the utilization margin could be a substantial benefit for economic and policy analysis. These additional statistics could increase the value of SPC at low incremental cost. 


\section{Data}

\section{Surveys}

Micro data on capacity and its utilization are collected in the Survey of Plant Capacity (SPC), which is conducted annually and for some years biannually by the U.S. Census Bureau. ${ }^{1}$ This survey is used by the Federal Reserve Board as a part of its benchmarking of Industrial Production and Capacity Utilization. It has also been used in a limited number of studies such as Shapiro (1993, 1996), Mattey and Strongin (1995), and Beaulieu and Shapiro (1995), and Beaulieu and Mattey (1998).

Typically, the sampling frame of SPC is constructed from the most recent Census of Manufactures. After 1999, sample selection was accomplished using a probability proportionate to size (pps) sampling method thus ensuring that the sample size desired for each industry was realized. In previous panel selections, sampling was conducted independently by unit, i.e., over repeated applications, the resultant sample size would vary around the expected size. The number of firms per survey varies between 8,000 firms in the 1970s and 1980s and 12,000 to 17,000 firms in 1990s and 2000s. Between Census years, the sample is typically replenished with 200-300 firms annually.

The SPC measurements can be divided into two broad categories. The first measures production at both actual levels and conjectural "full production capability" and "national emergency" levels. Capacity utilization is defined as the ratio of actual production to full production. The published data from the SPC relate solely to subjective measures of capacity utilization reported by survey respondents.

The second broad category measures several of the key margins for varying capacity utilization. These include the number of shifts, days per week, hours per week, and weeks per quarter the plant is in operation (by shift), the number of workers and their hours (by shift), and overtime hours (by shift). Number of shifts and the hours they operate are key determinants of capital utilization. We provide the groundwork for more general dissemination and use of these important data on capital utilization.

The SPC reports manufacturing level aggregates and industry level to the 4-digit SIC and, more recently, to the 6-digit NAICS level. It tabulates data for utilization rates relative to full

\footnotetext{
${ }^{1}$ This discussion is based on the most recent release of the SPC, Survey of Plant Capacity: 2006. U.S. Census Bureau Report MQ-C1(06), November 2007.
} 
production and national emergency levels of capacity. The published reports do not tabulate the detailed information collected in the SPC on the determinants of utilization rates, i.e., number of shifts, days per week, hours per week, and weeks per quarter the plant is in operation (by shift). These later data have been analyzed on occasion by researchers, either within the Center for Economic Studies based on plant level data linked to the Annual Survey of Manufactures (ASM) and Census of Manufactures (CM) or through 4-digit unpublished aggregates released to researchers by the Census Bureau. ${ }^{2}$ We follow the first strategy and merge the Census Bureau's Longitudinal Research Database (LRD) for 1963-2004, including the Census of Manufactures for census years, and the Annual Survey of Manufactures from 1972 onwards, and the Survey of Plant Capacity (SPC) for 1974-2004. Detailed description of the LRD, which is a merged ASM/CM dataset, is available in McGuckin and Pascoe (1988).

\section{Sample}

When we construct the utilization series we combine two data sets: Survey of Plant Capacity (SPC) and Annual Survey/Census of Manufactures (ASM/CM). The data sets are merged using unique plant identifiers. ${ }^{3}$ Capital utilization data at the establishment level is taken from SPC. Information on capital, labor and output is taken from ASM/CM. Some alternative measures of output and labor are taken from SPC. ${ }^{4}$ Sample weights are taken from SPC. In a typical year, SPC samples plants from ASM/CM plants. After merging SPC and ASM/CM, the resulting sample is about 7,000-12,000 establishments per year at the aggregate level, 100-800 establishments for an industry at the 2-digit SIC industry level, and about 25-100 establishments for an industry at the 3 digit SIC industry level.

\footnotetext{
${ }^{2}$ For example, research in Shapiro $(1993,1996)$ was made possible by release of unpublished data generously provided by the Bureau through the office of Elinor Champion.

${ }^{3}$ The files were linked using permanent plant numbers. In recent years (after 2002 Census), The US Census Bureau switched to a new system of plant identifiers. We use 2002 Census when both new and old plant identifiers are available to assign old PPNs to establishments after 2002. Note that SPC switched to new plant identifiers in 2004. In rare cases when PPN was missing or incorrectly coded, we use other firm identifiers (employer identification number, alpha-code, regional information, etc.) to find the correct PPN. Pulling all years together, we construct a bridge between this plant identifier to the permanent plant number. This dictionary has about 300,000 firms that ever appeared in SPC. In non-census years, about 6,000 to 10,000 plants in SPC can be matched to plants in ASM. In census years, the match is almost complete (in the worst 1997 year, about 1,000 firms in SPC cannot be matched to CM). Because surveys used different plant identifiers in 2002-2004, the quality of the match is somewhat lower than for other years. The worst match is for 2004, when SPC plant identifiers allow us to match only about 6,000 firms.

${ }^{4}$ In part, our objective was also to check consistency of the series across surveys.
} 
There are three main sources of differences in the samples used in constructing capital utilization series and samples used for publishing capacity utilization series by the US Census Bureau. First, some industries in SPC (notably parts of printing) are not covered by ASM/CM and therefore are excluded from our analysis. Here, we lose about 200-400 plants relative to the sample used by the US Census Bureau. Second, SPC has two subsamples. One subsample of plants is asked only capacity utilization questions ("short questionnaire"), while the other subsample is asked capacity utilization and plant hours questions ("long questionnaire"). We focus only on the "long questionnaire" subsample and hence the sample is further reduced by about 5,000 plants starting in the mid-1990s. Third, we could not match some plants in SPC to plants in ASM/CM due to replenishment of the SPC sample with new births, broken unique plant identifiers, etc. The sample is reduced by up to 100 plants per year for these reasons.

\section{Industry}

We use 1987 Standard Industrial Classification (SIC) to associate plants with industries. We had to recode industries from NAICS and other vintages of SIC. Our recoding procedure has several steps. First, for industries with one-to-one bridges between 1987 SIC and other industry classification, we assigned the industry based on the industry classification (either NAICS and other vintages of SIC) reported in the corresponding year. Second, for industries with no one-toone bridges, we use the 1987 SIC code available in the closest adjacent year. Third, for firms which had no 1987 SIC code and had one-to-many mapping from the reported industry code to 1987 SIC, we use probabilistic assignment into 1987 SIC industries.

For example, a plant in industry X in NAICS could be in industries Y1 and Y2 in 1987 SIC. From 1997 Census, we know the shares of Y1 and Y2 plants. Suppose that industry Y1 is twice as large as industry Y2. Then the probability of any given plant with NAICS classification to be assigned into industry Y1 is twice as large as the probability of being assigned into industry Y2. In short, with probabilities equal to shares of Y1 and Y2 we assign this plant into Y1 or Y2 1987 SIC industry. This probabilistic assignment was done for relatively few firms before 2004 and for about $50 \%$ of firms in 2004 for which the first two (non-probabilistic) strategies were not able to assign an unambiguous SIC 1987 code. We ensure that plants once assigned a 1987 SIC code keep the code as long as they continue to have the same NAICS or other-vintage SIC code. 
This prevents plants from jumping across industries over time when their original industry codes do not change.

The level of disaggregation for industry is 4-digit. However, we are more confident in the correctness of the classification at the 3-digit level. Finally, there is little (if any) scope for industry misclassification at the 2-digit level.

\section{Measurement and Aggregation}

\section{Measurement}

It is essential to distinguish between two useful, but distinct measurement concepts-capacity utilization and capital utilization. ${ }^{5}$ Capacity utilization is meant to capture the ratio of current output to a measure of full-capacity output. Capital utilization is meant to capture the rate at which the stock of installed capital is currently operated.

Capacity utilization, $C U$, can be defined as

$$
C U=Y / Y^{*} \text {, }
$$

where $Y$ is actual output and $Y^{*}$ is full-capacity output.

Capital utilization, $K U$, can be defined as multiplying the physical stock of capital, $K$, that yields a measure of capital services. ${ }^{6}$ For example, in a production function $F$ written in terms of capital, labor $L$, and other factors $X$, capital utilization would enter as ${ }^{7}$

$$
Y=F(K U \times K, L, X) .
$$

The level of $K U$ is important for determining output and capacity utilization. But other margins, specifically labor, energy, and materials use (parts of $X$ ) are also important in determining output and capacity utilization. Unobserved movements in factor utilization (e.g., line speed and worker's effort) are also important margins. How should $K U$ be measured? A leading contender is to measure $K U$ as plant hours, that is, number of shifts times hours per shift times days per week, etc. The Survey of Plant Capacity is the leading source of data for making this calculation. ${ }^{8,9}$ We develop systematic measures of capital utilization along these lines.

\footnotetext{
${ }^{5}$ See Betancourt and Clague (1981), Shapiro (1989), Corrado and Mattey (1997), for example, for discussion of the conceptual basis of capital utilization measurement. See Shapiro and Corrado and Mattey especially for the relationship of the Federal Reserve Board's measure of capacity utilization to the concept of capital utilization.

${ }^{6}$ This one-dimensional formulation of utilization is a stylization of a multi-dimensional problem.

${ }^{7}$ See Basu, Fernald, and Shapiro (2001) for a more complete discussion of the observed and unobserved utilization margins.

${ }^{8}$ Foss (1981) is an early example of the use of capital hours to measure capital utilization.
} 
Previous literature uses several proxies for the rate of $K U$ when $K U$ is not directly measured:

1. Labor hours (including regular and overtime hours). The key presumption is that more labor input is typically required to run machines longer or more intensively. This measure is the most widely available.

2. Number of shifts. This measure works the best for industries with conveyer-type production. Number of shifts is less frequently measured, though is available in the dataset we use.

3. Number of workers. This measure is best suited for industries with workstation-type production. ${ }^{10}$ For these industries, it is typical to observe that as capital is employed more intensively, more workers are hired. Sometimes, the share of temporary workers is used to proxy for capital utilization rate.

4. Input of materials and energy. This approach works the best for continuous process industries (e.g. petroleum). The reason is technological: the cheapest margin to vary for these industries is the flow rate of inputs, while labor input is normally fixed and capital is usually run seven days a week in three shifts.

The first three proxies can be combined. For example, to produce a proxy for $K U$, number of workers per shift and workweek of labor can be combined as in Shapiro (1986):

$$
S=\frac{\left[H\left(L_{1}-L_{2}\right)+80\left(L_{2}-L_{3}\right)+120 L_{3}\right]}{L_{1}}
$$

where $L_{i}$ is the number of workers in the $i^{\text {th }}$ shift, $H$ is the workweek of labor. Empirical research has been using the workweek of labor or related labor proxies since these have been the only available indirect measures of capital utilization. In contrast, SPC collects information on shiftwork and plant hours so that more and better data can be used to construct aggregation weights and $K U$ measures by combining these basic proxies of $K U$.

Naturally, the questions are why labor input is a good proxy and if there are better proxies. Shapiro (1986), Mayshar and Halevy (1997), Basu, Kimball, and Fernald (2006), and

\footnotetext{
${ }^{9}$ One alternative is the Industry Wage Survey, that provides number of shifts, but with spotty coverage and poor linkage to other data. Another alternative is to use CPS data on shiftwork, but again this is only occasionally available and not linked with other data for the worker's plant.

${ }^{10}$ Literature on capital utilization classifies production into three major types: assembly line (e.g. automobile conveyer), continuous process (e.g. oil refinery), and workstation type (e.g. garment factory).
} 
Basu, Fernald and Shapiro (2001) present a theoretical framework to address these questions, in particular how to model the choice of $K U$ rate at micro level. The basic idea is that marginal benefit from adjusting $K U$ must be equal to the marginal cost of adjusting this margin, most importantly labor compensation for extra/overtime hours, second shifts, etc. Under certain conditions - as Basu, Fernald and Shapiro show - utilization rate is determined for each firm $i$ as a solution to firm's dynamic optimization problem. Specifically,

$$
d u_{i}=\left[\frac{\eta_{i}}{v_{i}}\left(s_{K, i}^{*}-\phi_{i}\right)+\zeta_{i}\left\{s_{L, i}^{*}-\psi+\left(\frac{r \psi N}{R}\right)^{*}\right\}\right] d h_{i}
$$

where $d x$ denotes deviation of variable $x$ from its steady state, $u$ is the utilization rate, $h$ is labor hours, $\eta$ is the elasticity of labor costs with respect to hours, $v$ is the elasticity of labor costs with respect to capital utilization, $s_{K}^{*}$ is the factor share of capital in output, $\phi$ represents the cost of adjusting capital stock, $\zeta$ is the elasticity of effort with respect to hours per worker, $s_{L}^{*}$ is the factor share of labor in output, $\psi$ stands for costs of adjusting labor, $R / N$ is the ratio of gross hiring to employment, $r$ is real interest rate. Stars indicate steady state values. The first term is the direct increase in overtime premium due to overtime hours. The second term shows the cost of adjusting workers' effort. ${ }^{11}$

This theoretical result shows that utilization is determined simultaneously with labor input and, hence, labor input can be used as a proxy for $K U$. This justifies weighting by employment and, to some extent, by output. Of course, other margins of adjustment, e.g. capital stock, energy and materials, can be equally important for determination of $K U$. Conditions similar to (3) can be easily derived. The success of a $K U$ measure depends on specifics of the technology employed by a firm. Condition (3) is particularly applicable for the assembly-line and workstation types of production and to lesser extent to the continuous process production.

\section{Aggregation}

How should $K U$ be aggregated? Specifically, what is a weight that can be used to scale the physical capital stock to yield a capital services measure to be used in a production function such as equation (2)? The theoretically-mandated weight to make $K U \times K$ the appropriate measure of capital services is the size of the physical capital stock. Yet, whether weighting by the share of a plant's capital works well statistically is an open question.

\footnotetext{
${ }^{11}$ Shapiro (1986) derives a similar condition when adjustment of all inputs is costly.
} 
To understand why the issue of weighting is important, consider some alternatives. For example, aggregation based on weights derived from either output or employment tends to overstate utilization rates. Specifically, consider two plants with the same physical capital and same capital-labor ratio, but one that operates three shifts and one that operates one shift. The three-shift plant would have three times the output and employment of the one-shift plant. In this simple example, the number of shifts, $S$, is a good proxy for capital utilization. Weighting by capital, the average number of shifts would be

$$
S=0.5 \times 1+0.5 \times 3=2.0 .
$$

Weighting by employment or output, the average number of shifts would be

$$
S=0.25 \times 1+0.75 \times 3=2.5 .
$$

In the second calculation, the multiple shift plant gets overweighted precisely because of the output (or employment) from the multiple shifts. Because the extra labor entailed in staffing the multiple shifts is already counted in $L$ in production function (2), using the second measure overcorrects for capital utilization. (This is easiest to see by assuming that the production function is constant returns to scale and expressing output and inputs on a per-shift basis.)

Hence, to compute utilization rate at industry level, the weighting by capital implies the following formula:

$$
\overline{K U}_{j t}^{(K)}=\frac{\sum_{i=1}^{N} K U_{i j t} K_{i j t}}{\sum_{i=1}^{N} K_{i j t}}=\sum_{i=1}^{N} K U_{i j t} \omega_{i j t}^{K}
$$

where $j, i, t$ index industry, firm, and time respectively, $K U$ stands for utilization rate, $K$ is capital, and $\omega_{i j t}^{K}$ is firm $i$ 's share of capital in industry $j$ 's capital. This approach is easily generalized to computing capital utilization for the economy:

$$
\overline{K U}_{t}^{(K)}=\frac{\sum_{j=1}^{M} \overline{K U}_{j t} K_{j t}}{\sum_{j=1}^{M} K_{j t}}=\sum_{j=1}^{M} \overline{K U}_{j t}^{(K)} \omega_{j t}^{K}
$$

where $M$ is the number of industries and $K_{j t}$ is capital stock in industry $j$ at time $t$.

If the capital data prove problematic for weighting (e.g., because capital can be poorly measured), the above analysis suggests a conceptual framework for alternatives, which can be also used to evaluate weighting by capital. Specifically, the weighting should be carried out at a constant (across plant) level of utilization. In this regard, the SPC data on utilization rates might be a fruitful avenue for producing constant-utilization employment or output weights. 
To illustrate the point, consider a straightforward alternative of weighting by employment in the largest shift:

$$
\overline{K U}_{j t}^{(L)}=\frac{\sum_{i=1}^{N} K U_{i j t} L_{i j t}}{\sum_{i=1}^{N} L_{i j t}}=\sum_{i=1}^{N} K U_{i j t} \omega_{i j t}^{L}
$$

where $L$ is employment on the largest (most likely the first) shift ${ }^{12}$, and $\omega_{i j t}^{L}$ is share of firm $i$ in employment of industry $j$ at the largest shift at time $t$. Labor input is measured more precisely than capital, thus there is a tradeoff between economic rigor, which favors weighting by capital, and precision of estimates, which may favor weighting by employment on the largest shift. To evaluate the bias in the labor-weighted utilization rate, we suggest focusing on industries with relatively precisely measured capital (i.e., ones with consistent estimates of capital across data sets, precisely measured depreciation rates, etc) and estimating the bias from labor-weighted utilization rates for these industries. Likewise, weighting by output (with weights $\omega_{i j t}^{Y}$ ) is possible.

The potential problem with using $\omega_{i j t}^{L}$ or $\omega_{i j t}^{Y}$ instead of $\omega_{i j t}^{K}$ is that firms with high $K U$ are overweighed in aggregation. Basically, firms with high employment/output would tend to have higher weights and higher $K U$ rates. Thus, the constructed measure of aggregated $K U$ can have a significant upward bias. However, idle capital is particularly expensive for capitalintensive plants (e.g., oil refineries) and hence capital for these plants is likely to be utilized more intensively. In this scenario, weighting by capital stock may produce estimates substantially larger than estimates of capital utilization based on weighting by output or labor input. Thus, although weighting by labor or output may overstate the cyclicality of capital utilization it may at the same time understate the level of capital utilization.

\section{Time series of aggregate measures of capital utilization Definitions}

We construct three series of capital utilization: average plant hours per week (PHW); average plant hours per day (PHD); average number of plant days in operation per week (POD). Given the discussion in the previous section, we consider several weights to construct the series. Let $i$ and $t$ index establishments and time (year). Denote a reported measure of capital utilization with $K U_{i t}$ (i.e., $K U$ can be PHW, PHD or POD); sample weights with $w_{i t}$; a measure of output with

\footnotetext{
${ }^{12}$ Other reasonable combinations of measures discussed above can be used for $L$.
} 
$Y_{i t}$; a measure of capital stock with $K_{i t}$; a measure of employment with $L_{i t}$. We construct the following series:

- $\quad$ simple average (use only sampling weights):

$$
\overline{K U}_{t}=\frac{\sum_{i} K U_{i t} w_{i t}}{\sum_{i} w_{i t}}
$$

- weighted by output (total value of shipments from the most recent Census of Manufactures):

$$
\overline{K U}_{t}^{(Y)}=\frac{\sum_{i} K U_{i t} w_{i t} Y_{i t}}{\sum_{i} w_{i t} Y_{i t}}
$$

- weighted by capital stock (balance sheet value of fixed assets from the most recent Census of Manufactures):

$$
\overline{K U}_{t}^{(K)}=\frac{\sum_{i} K U_{i t} w_{i t} K_{i t}}{\sum_{i} w_{i t} K_{i t}}
$$

- weighted by sample weights and employment (total number of employees from most recent Census of Manufactures $)^{13}$ :

$$
\overline{K U}_{t}^{(L)}=\frac{\sum_{i} K U_{i t} w_{i t} L_{i t}}{\sum_{i} w_{i t} L_{i t}}
$$

\section{Filters}

Since the distributions of sales, capital and employment are strongly skewed, we construct series adjusted for influential observations. ${ }^{14}$ To understand the reason for this adjustment, consider $\overline{K U}_{t}^{(Y)}$. The effective weight for plant $s$ in this measure is given by $w_{s t} Y_{s t} / \sum_{i} w_{i t} Y_{i t}$. Note that sample weight $w_{s t}$ and measure of output $Y_{s t}$ can lead to a very large weight $w_{s t} Y_{s t}$. This is not desirable because time series can be dominated by reporting errors, unusual events and other irregularities so that the resulting aggregate time series can be choppy and driven by untypical circumstances.

We apply the following procedure to limit the effect of extreme observations. In the first screening step, we jackknife (i.e., drop one plant at a time) capital utilization for a given industry/year and compute the statistics of capital utilization. Suppose that this industry and year has $N$ plant observations. After applying the jackknife, we have $N$ values of the capital utilization statistic. The distribution of this statistic informs us about the effect of any given observation on

\footnotetext{
${ }^{13}$ Additional statistics based on the replacement value of capital and total hours of production workers are available upon request.

${ }^{14}$ Series not adjusted for influential observations are available upon request.
} 
the statistic we want to report (e.g., mean value of capital utilization rate). We say that an observation is potentially influential if the statistic computed without this observation is outside the range of median plus/minus four interquantile ranges where median and interquantile range are computed on the basis of $N$ statistics from the jackknife. We say that an observation is influential if it is potentially influential and its weight $w_{s t} Y_{s t}$ is above $90^{\text {th }}$ percentile of the weights $w_{s t} Y_{s t}$ for a given industry and year. In short, influential observations have very large weights $w_{s t} Y_{s t}$ and move the industry level measure of capital utilization by large amounts. For influential observations, we limit the weight $w_{s t} Y_{s t}$ to be equal to the $90^{\text {th }}$ percentile of the weights $w_{s t} Y_{s t}$ for a given industry and year. Note that we do not drop influential observations and we do not recode firm-level measures of capital utilization for influential observations. Figure 1 illustrates the importance of controlling for observations with unusually large effective weights for some industry in 1991: censoring the weights at the $90^{\text {th }}$ percentile increases average plant hours by almost 10 hours.

\section{Series}

Figure 2 shows the effects of using capital stock in constructing aggregate measures of capital utilization. ${ }^{15}$ Note that simple average of capital utilization is substantially smaller than the aggregate capital utilization computed with capital stock as one of the weighting variables. This pattern is apparent for all dimensions of capital utilization: plant hours per week or day and days in operation. Adjustment for influential observations reduces measured capital utilization quite substantially, especially for days in operation. Despite differences in the level of aggregate capital utilization, the series based on alternative weighting schemes comove strongly and have similar time series properties (persistence, volatility of innovations, etc.)

Figure 3 presents times series of capital utilization based on weighting by capital, sales and employment. Applying different variables to weight capital utilization has dramatic effects on the level of utilization. Weighting by employment and sales leads to measures of capital utilization approximately $20 \%$ and $10 \%$ smaller respectively than the same measures of capital utilization based on weighting by capital stock. Hence, weighting by employment and sales understates the aggregate level of capital utilization.

\footnotetext{
${ }^{15}$ In all series we construct, year 1998 is missing because much of information on plant hours, shifts, workweek of capital, etc. were miscoded and we were not able to recover the correct data.
} 
Figures 2 and 3 show that there is an important correlation between capital intensity and capital utilizations: firms with large capital stock tend to utilize capital more intensively. For example, oil refineries or car assembly plants are strongly capital intensive and the opportunity cost of capital being idle is high relative to shift or overtime premium paid to workers. In contrast, for labor intensive firms (e.g., apparel) the labor costs due to firms shift or overtime premium dominate the opportunity cost of idle capital stock.

In a series of robustness checks, we examine whether our conclusions are sensitive to using alternative measures of output, employment, and capital. Broadly, the levels of capital utilization are similar across alternative measures of capital stock (see Appendix Figure 1). Our preferred measure of capital stock, which is the historical cost of structures and equipment from the most recent Census of Manufactures, is less volatile than alternative measures. This reflects the fact that after 1992 SPC did not sample firms from the Annual Survey of Manufactures and hence the sample of firms for which we can construct capital stock using perpetual inventory is smaller. Before 1992, the difference between alternative measures of capital stock is small.

Figure 4 presents the effects of using hours, number of employees, and the number of employees in the first shift (typically the largest shift) on aggregate measures of capital utilization. The general pattern is that using hours or number of employees (from the most recent Census of Manufactures) leads to similar results (with the number of employees producing somewhat larger levels of aggregate capital utilization). Weighting by employment in the first shift (which is taken from the current SPC) somewhat strongly lowers the level of plant hours per day but does not have a large effect on days in operation. Using sales from current SPC or from the most recent Census of Manufactures does not have any material effects on the aggregate measures of capital utilization weighted by sales (see Appendix Figure 2).

Importantly, across all measures of capital utilization we observe a slowdown in the growth of the intensity of capital utilization. More specifically, practically all measures of aggregate capital utilization exhibit a strong upward trend before the mid-1990s and then capital utilization flattens or even declines. This finding is striking given that capital utilization has been steadily increasing for decades (Foss 1981).

More formally, we find that quadratic time trend has a much better fit than the simple linear trend model with a marked turning point in mid 1990s. To test for the break rigorously, we 
use Andrews (1993) test to identify the break point $\tau$. In particular, we search over potential dates using the following specification:

$$
K U_{i t}=\alpha+\beta t+\gamma(t-\tau) \mathbf{1}(t \geq \tau)+\lambda_{i}+\text { error },
$$

where $\mathbf{1}(t \geq \tau)$ is the dummy variable equal to one if year is greater than or equal to year $\tau$ and zero otherwise, $\lambda_{i}$ is industry fixed effects (if run on industry-level data). Identified break dates are reported in Table 1. In all cases we reject the null of no breaks in capital utilization series at all conventional significance levels. The change in the trend growth of capital utilization is also economically significant. Before the break, a typical growth rate is between $1 / 2$ and one percent per year. After the break, a typical growth rate is zero or negative. The timing of the break varies across series from as early as 1991 to as late as 1997 when we use aggregate series. The range for the break dates shrinks to 1995-1997 when we use industry series.

It is possible that the recent decline in capital utilization is due to shifts in the composition of industries. Figure 5 presents the time series of capital utilization at the two-digit SIC level. First, we observe that capital utilization varies substantially across industries. Second, the slowdown or downturn in capital utilization after mid 1990s is broad based. Third, the discrepancy between industry-level capital utilization measures weighted by capital, sales and employment can be substantially smaller relative to the discrepancies we observed in aggregate series. This is especially true for industries dominated by small firms (e.g., apparel, furniture). For industries dominated by large plants (e.g., oil refinery, chemical, paper) the choice of weighting variable continues to play a very important role. Fourth, the time series properties of our capital utilization measures appear to be largely insensitive to the choice of the weighting variable. The correlation between measures of capital utilization based on alternative weighting variables is routinely in 0.8-0.9 range and the level of growth rates is approximately the same.

\section{Summary}

Our preferred measure of capital utilization is plant hours per day, weighted by capital and adjusted for outliers. In what follows, we compare results using this variable to using alternative measures.

We have prepared an online database of the various measures of capital utilization. It is available at http://www.umich.edu/ shapiro/data/SPC. 


\section{Variable capital utilization in macroeconomic relationships}

Total factor productivity and capital utilization

Measured productivity is procyclical. One important reason for this procyclicality is unaccounted-for variation in factor utilization. ${ }^{16}$ There are a variety of ways to evaluate the performance of productivity measures in combination with data from the ASM-CM. In particular, we study to what extent changes in capital utilization can account for changes in production that cannot be accounted for by changes in other inputs. Specifically, we estimate the following regression:

$$
\Delta T F P_{j t}=\beta \Delta \overline{K U}_{j t}+\lambda_{j}+\theta_{t}+v_{j t}
$$

where $j$ and $t$ index industries and time, TFP is total factor productivity and $\lambda_{j}, \theta_{t}$ are industry and year fixed effects. We estimate this specification by ordinary least squares (OLS) and instrumental variable (IV) estimators at the aggregate and 2-digit SIC level. Since the reverse causality is evidently possible, IV is preferred to OLS. Our instrumental variables are from Basu, Fernald and Kimball (2004): monetary policy shocks and oil price shocks.

We consider three measures of TFP. The first TFP measure is from CES-NBER productivity data set constructed by Bartelsman, Becker and Gray (2002; henceforth BBG). The second TFP measure is from Basu, Fernald and Kimball (2004; henceforth BFK). The difference between BFK and BBG measures is that, when aggregating productivity series to the 2-digit and higher level, BFK correct for general equilibrium effects by adjusting the series with the share of materials. The third TFP measure is the purified Solow residual from BFK. The key difference between purified TFP and other measure of TFP is that purified TFP corrects for unobserved factor utilization using observed choices of firms. The links between observed (e.g., hours) and unobserved (e.g., effort) margins are derived similar to equation (3).

We report estimation results in Table 2 through Table 4. Generally we find that TFP series are correlated with capital utilization measured by plant hours per week. ${ }^{17}$ However, the correlation is positive for raw TFP series and negative for the purified TFP. This negative correlation may be interpreted in a number of ways. A plausible scenario appears to be that adjustments for variable factor utilization are too large thus inducing a negative correlation

\footnotetext{
${ }^{16}$ Solow (1957) made this point in his classic article on total factor productivity. See Shapiro (1996) and Basu, Fernald, and Shapiro (2001) for recent applications of this point.

${ }^{17}$ Additional results for capital utilization measured by plant hours per day and days in operation per week are available in Appendix A.
} 
between capital utilization (previously unobserved margin) and TFP. We observed similar patterns when we estimate the same specification by industry (Table 5).

To explore the importance of capital utilization as a margin of adjustment, we correct measures of TFP for capital utilization and examine how these corrected measures are correlated with observed changes in inputs. Specifically, we compute the utilization-corrected measures of TFP as follows:

$$
\Delta \widetilde{T F P}_{j t}=T F P_{j t}-\alpha_{K} \Delta \overline{K U}_{j t}
$$

and then estimate

$$
\Delta \widetilde{T F P}_{j t}=\beta \Delta X_{j t}+\lambda_{j}+\theta_{t}+v_{j t}
$$

where $\Delta X_{j t}$ is the change in capital stock, labor, material and other inputs weighted by appropriate cost shares, $\alpha_{K}$ is the capital cost share. As a benchmark, we also run the same specification using the raw measure of TFP (i.e., without correcting for capital utilization):

$$
\Delta T F P_{j t}=\beta \Delta X_{j t}+\lambda_{j}+\theta_{t}+v_{j t}
$$

Table 6 shows that utilization-corrected measures of TFP are less strongly correlated with $\Delta X_{j t}$ (especially at the aggregate level and for the BBG measure of TFP). This finding is in line with Shapiro $(1993,1996)$ who finds that once variation in $K U$ is taken into account, the Solow residual is approximately white noise. However, correcting for variable capital utilization does not always completely remove the correlation with inputs thus suggesting that correction for other inputs may be necessary.

Indeed, capital utilization is only one margin of factor utilization. Others include observed changes in hours of workers and unobserved changes in effort and line speed. Different researchers have suggested different proxies. These include capital hours (Shapiro 1993, 1996), materials (Basu, 1996), energy (Burnside, Eichenbaum, and Rebelo, 1995), and average weekly hours of production workers (Basu, Fernald, and Shapiro, 2001). Shapiro (1996) presents a simple framework to evaluate 1) performance of various measures of capital utilization and 2) (cyclical) contribution of capital utilization measures - given other covariates such as materials, energy, etc. - to accounting for variation in output. The basic idea is to run horserace regressions and test if a variable works like a sufficient statistic, i.e., information contained in this variable is sufficient to describe the behavior of the dependent variable. For example, it is important to determine if energy, which is one of the proxies for unobserved speed of conveyer, significantly 
contributes to explaining variation in output given information about capital utilization. If $K U$ is a sufficient statistic, then the coefficient on energy should be statistically not different from zero.

We consider the following specification:

$$
\Delta T F P_{j t}=\beta \Delta \overline{K U}_{j t}+\gamma \Delta Z_{j t}+\lambda_{j}+\theta_{t}+v_{j t}
$$

where $Z$ is a measure of factor utilization. We present results for horserace regressions in Table 7 for aggregate series and Table 8 for industry-level series. Broadly, different measures of factor utilization are equally strong in predicting measures of productivity. In part this reflects the fact that various measures of capital utilization are correlated with measures of utilization for other factors of production. However, capital utilization clearly contains information not available in other measures of factor utilization.

\section{Capacity utilization}

To support the claim that other margins are important in accounting for utilization of other factors, we regression a measure of capacity utilization $(C U)$ on various measures of factor utilization:

$$
\Delta C U_{j t}=\beta \Delta \overline{K U}_{j t}+\gamma \Delta Z_{j t}+\lambda_{j}+\theta_{t}+v_{j t}
$$

and again examine if any measure of factor utilization works like a sufficient statistics. We find (Table 7 and Table 8) that capital utilization significantly contributes to variation in capacity utilization (esp. for non-continuous industries) and hence it should be included in the analysis of the slack in the economy of industry.

\section{Capital utilization and capital stock}

Increasing the quantity of capital and increasing its utilization are two competing margins for adjusting output. These margins can be studied in the context of the dynamic optimization problem of the firm. Shapiro (1986) and Basu, Fernald and Shapiro (2001) present a general framework to analyze how factor inputs and utilization rate covary. In fact, construction of weights to aggregate $K U$ rates and analysis of variation in $K U$ are naturally interrelated. Shapiro (1986) shows that capital stock and capital utilization margins are determined from first order optimization conditions like in (3) that can be cast as moment conditions for GMM-type estimation. We, however, take a more descriptive route to document the facts and leave interpretation to future work. 
We report cross-correlations of changes in capital utilization and capital stock in Figure 6. In general, changes in capital utilization lead changes in capital stock. Likewise, we find that changes in capital utilization lead changes in the labor input. At the same time, changes in capital utilization are coincident with changes in materials. These results suggest that capital utilization is a more flexible margin than capital and labor and that it contains useful information about future changes in capital and labor. Interestingly, we do not find any similar pattern in the crosscorrelations of changes in capital utilization and changes in TFP (Figure 7).

\section{Concluding remarks and recommendations}

Capital utilization is an important margin for understanding fluctuations in output at the plant and aggregate level and in firms' decisions about adding or subtracting from their stocks of factors of production as well as for understating and enhancing measures of productivity. Importantly, economic analyses of capital utilization cannot be divorced from the measurement issues.

The paper documents a number of facts about properties of capital utilization. First, after growing for decades, capital utilization started to fall in the mid-1990s. Second, capital utilization is a useful predictor of changes in capacity utilization and other factors of production. Third, adjustment of productivity measures for variable capital utilization improves statistical and economic properties of these measures. Fourth, the paper constructs weights to aggregate firm level capital utilization rates to industry and economy level, which is the major enhancement to available data.

Survey of Plant Capacity (SPC) is an extremely useful data set for understanding and measuring capital utilization. Given our results, we suggest several possible improvements to the survey. First, since weighting by capital stock is more appropriate for constructing aggregate measures of capital utilization, sample weights based on capital stock may enhance statistical properties of capital utilization series (e.g., reduce the effect of sampling errors) relative to the current sales-based sampling. Second, we suggest including consistency checks (introducing a "total" column in the form) to the survey forms to minimize misreporting of utilization series. Third, we suggest collecting more demographics on firms, especially historical cost of structures, equipment, and software. The value of this incremental information would be particularly high for constructing weights based on capital stock to aggregate capital utilization to an industry or 
economy levels. Alternatively, sampling from ASM frame could reduce the cost of collecting additional information in SPC and improve the compatibility of SPC and ASM. 


\section{References}

Basu, S. Procyclical Productivity: Increasing Returns or Cyclical Utilization? Quarterly Journal of Economics 111 (1996) 719-751.

Basu, S., F.G. Fernald, and M.D. Shapiro. Productivity Growth in the 1990s: Technology, Utilization, or Adjustment? Carnegie-Rochester Conference Series on Public Policy 55 (2001) 117-165.

Basu, Susanto, John G. Fernald, and Miles S. Kimball, 2006. "Are technology improvements contractionary?" American Economic Review 96(5), 1418-1448.

Beaulieu, J.J. and J. Mattey. The Workweek of Capital and Capital Utilization in Manufacturing. Journal of Productivity Analysis 10 (October 1998) 199-223.

Beaulieu, J.J. and M.D. Shapiro. Capital Utilization, Factor Productivity, and Returns to Scale: Evidence from Plant-Level Data, Board of Governors of the Federal Reserve System, Dec. 1995.

Betancourt, R.R. and C.K. Clague. Capital Utilization: A Theoretical and Empirical Analysis. Cambridge: Cambridge University Press, 1981.

Burnside, C., M. Eichenbaum, and S. Rebelo. Capital Utilization and Returns to Scale. NBER Macroeconomics Annual 10 (1995) 67-110.

Corrado, C. and J. Mattey. Capacity Utililization. Journal of Economic Perspectives 11 (Winter 1997) 151-67.

Foss, M. Changes in the Workweek of Fixed Capital. Washington, D.C.: American Enterprise Institute, 1981.

Jarmin, Ron S. and Javier Miranda, 2002. “The Longitudinal Business Database,” Working Papers 02-17, Center for Economic Studies, U.S. Census Bureau.

Mayshar, Joram and Yoram Halevy, 1997. "Shiftwork." Journal of Labor Economics 14 (No. 1., Part 2: Essays in Honor of Yoram Ben-Porath) S198-S222.

Mattey, J. and S. Strongin. Factor Utilization and Margins of Output Adjustment. Federal Reserve Board DEDS Discussion Paper 95-12. March 1995.

Mcguckin, R.H., and G.A. Pascoe, 1988. "The Longitudinal Research Database (LRD): Status And Research Possibilities,” Working Papers 88-2, Center for Economic Studies, U.S. Census Bureau.

Shapiro, M.D. Assessing Federal Reserve Measures of Capacity and Utilization. Brookings Papers on Economic Activity (1:1989) 181-225.

Shapiro, M.D. Capital Accumulation and Capital Utilization: Theory and Evidence. Journal of Applied Econometrics 1 (July 1986) 211-234.

Shapiro, M.D. Cyclical Productivity and the Workweek of Capital. American Economic Review Papers and Proceedings 83 (May 1993) 229-233.

Shapiro, M.D. Macroeconomic Implications of Variation in the Workweek of Capital. Brookings Papers on Economics Activity (2:1996) 79-133.

Solow, R.M. Technical Change and the Aggregate Production Function. Review of Economics and Statistics 39 (1957) 312-320.

Survey of Plant Capacity. Current Industrial Reports MQ-C1. U.S. Bureau of the Census. 
Figure 1. Effect of influential observations.

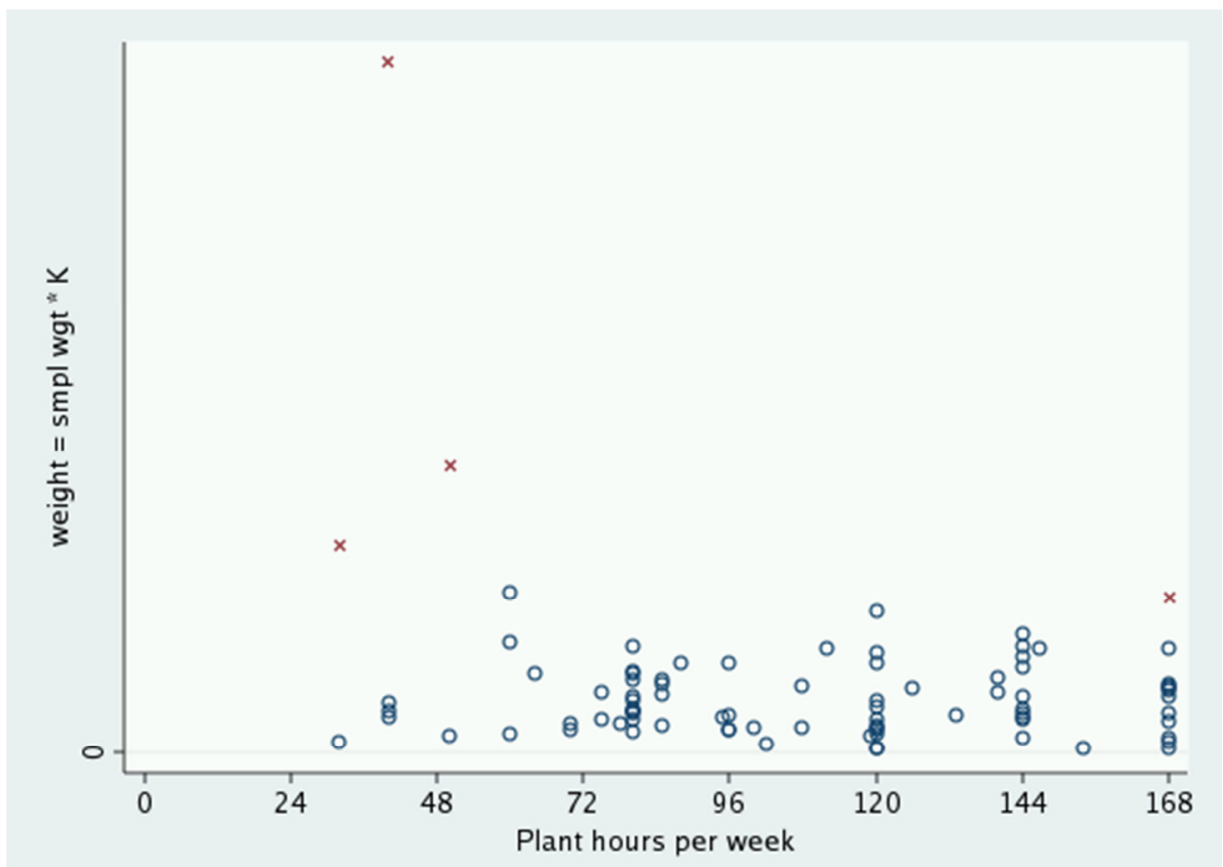

Notes: Crosses denote influential observations with large weights. Circles are regular observations. Plant hours per week in this industry is 106 without influential observations and 97 with influential observations. 


\section{Figure 2. Capital utilization.}
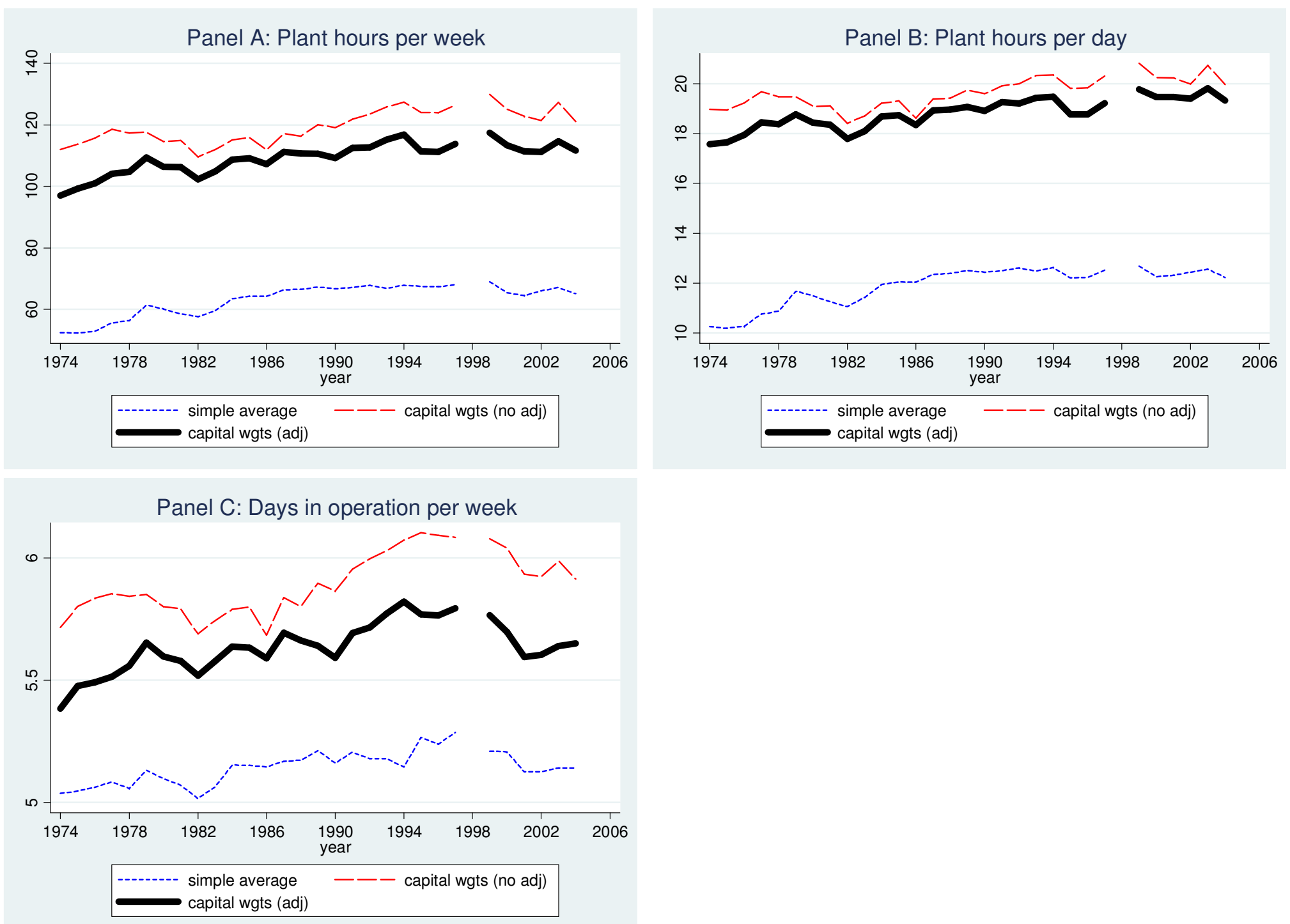

Notes: "simple average" corresponds to capital utilization measure described by equation (4). "Capital wgts" corresponds to capital utilization measure described by equation (6) where "no adj"/"adj" indicates whether the series is adjusted for influential observations. Capital is from the most recent Census of Manufactures. 
Figure 3. Aggregation of capital utilization with weighting by capital, sales and employment.
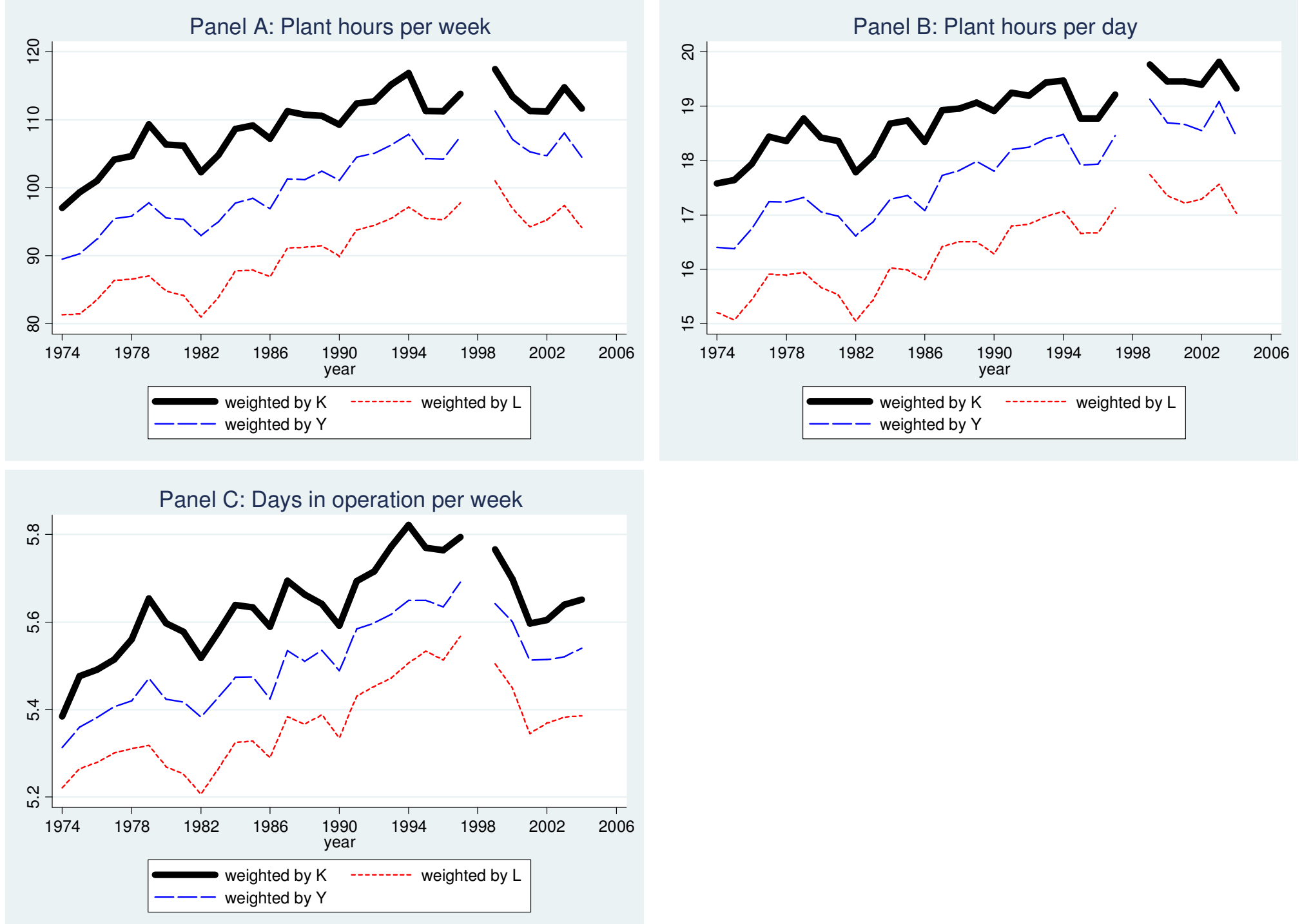

Notes: "weighted by K", "weighted by Y", and "weighted by L" corresponds to capital utilization measure described by capital [eq. (6)], sales [eq. (5)] and employment [eq. (7)] respectively. All series are adjusted for influential observations. Capital is the historical cost of structures and equipment from the most recent Census of Manufactures, sales are from the most recent Census of Manufactures, employment is the number of employee from the most recent Census of Manufactures. 
Figure 4. Aggregation of capital utilization with weighting by alternative measures of employment.
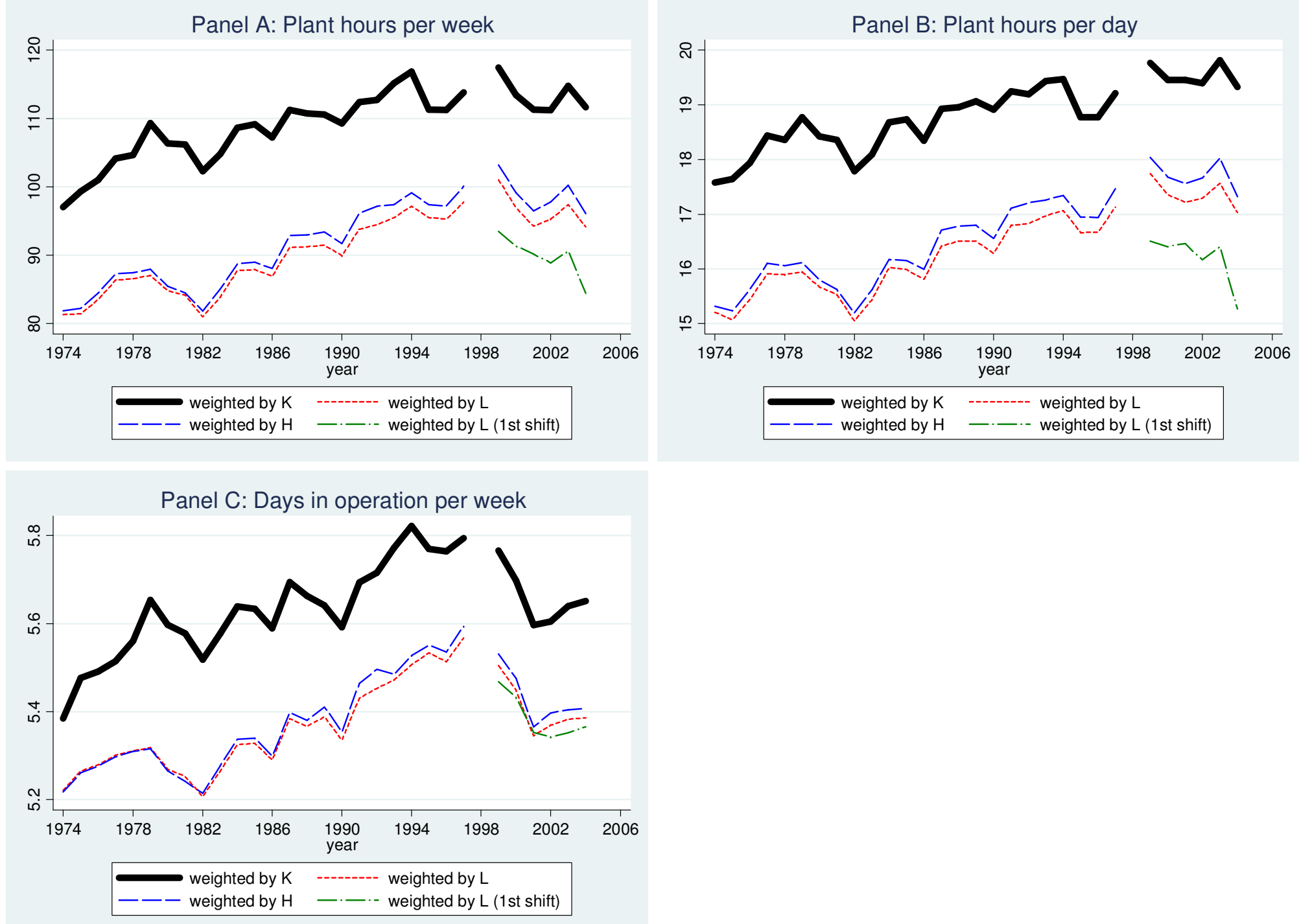

Notes: "weighted by K" and "weighted by L, H, L ( $1^{\text {st }}$ shift)" corresponds to capital utilization measure described by capital [eq. (6)] and employment [eq. (7)] respectively. All series are adjusted for influential observations. Capital is the historical cost of structures and equipment. Employment L is the number of employees from the most recent Census of Manufactures. Employment $\mathrm{H}$ is the number of employees from the most recent Census of Manufactures. Employment L $\left(1^{\text {st }}\right.$ shift $)$ is the number of employees in the first shift from SPC. 
Figure 5. Industry level measures of capital utilization.

SIC 20: Food and kindred products
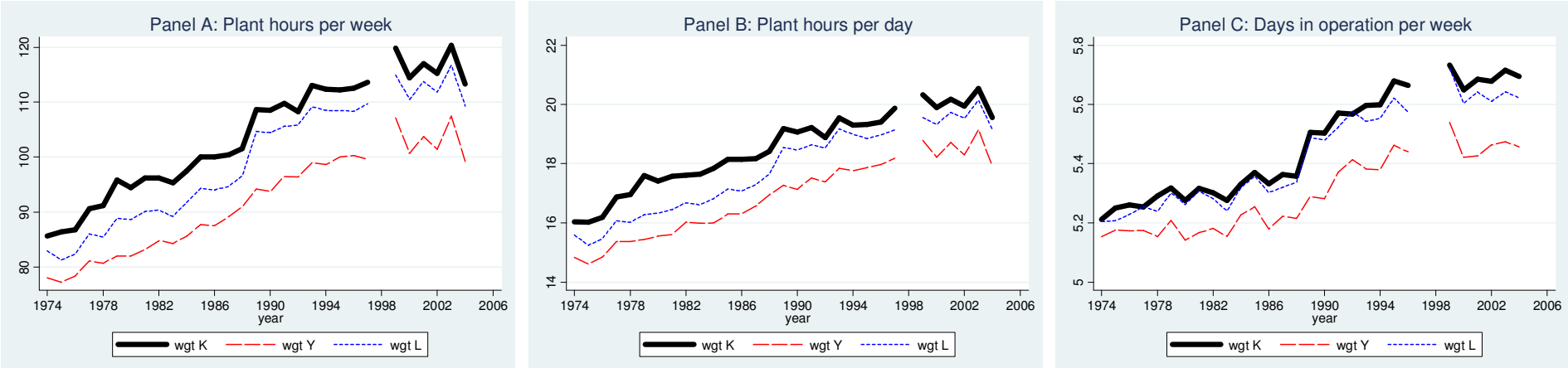

SIC 21: Tobacco manufactures
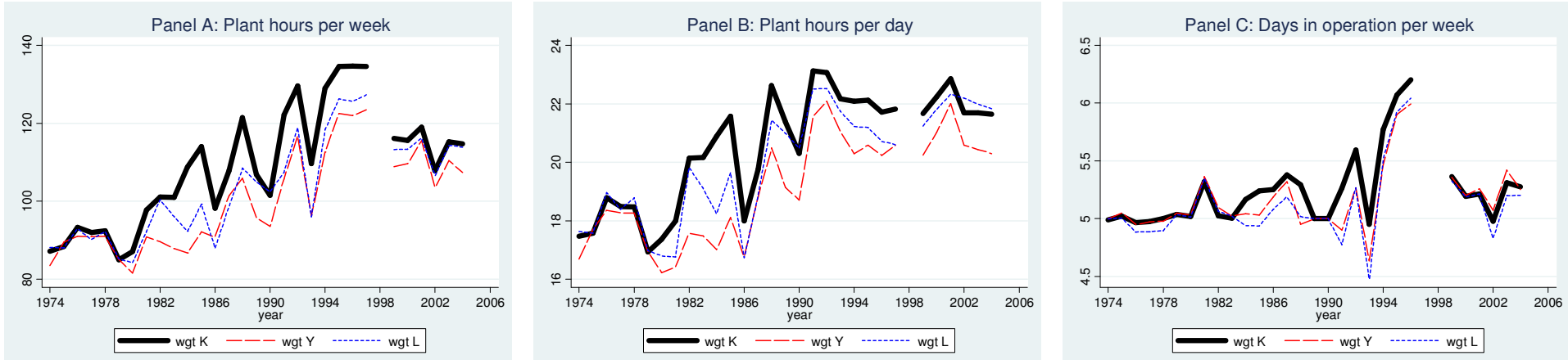

SIC 22: Textile mill products
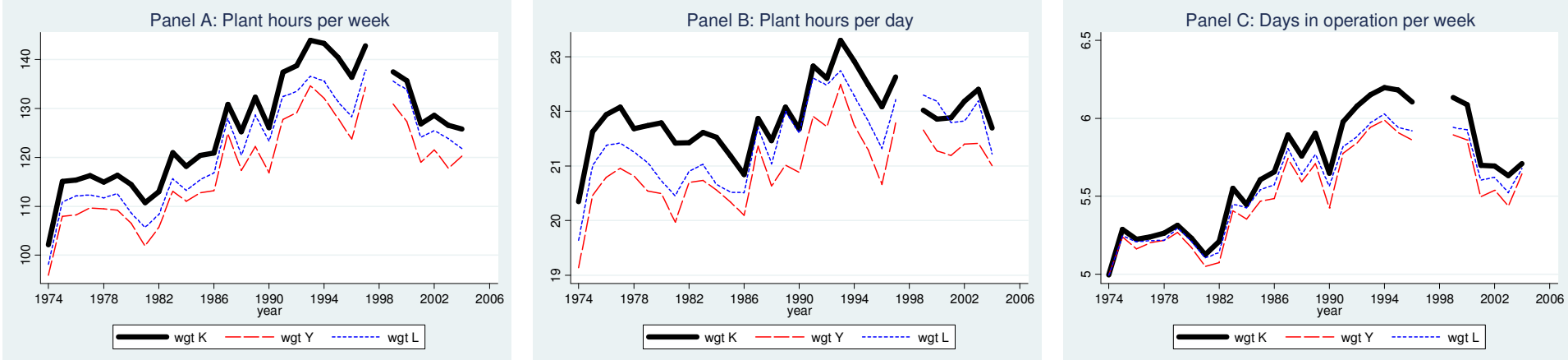

SIC 23: Apparel and other textile products
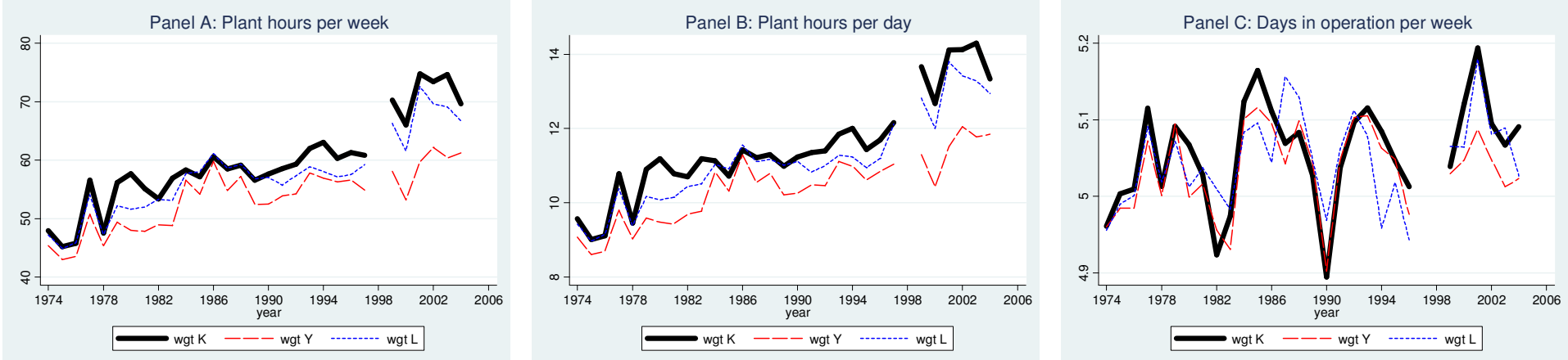

(continued on next page) 
SIC 24: Lumber and wood products
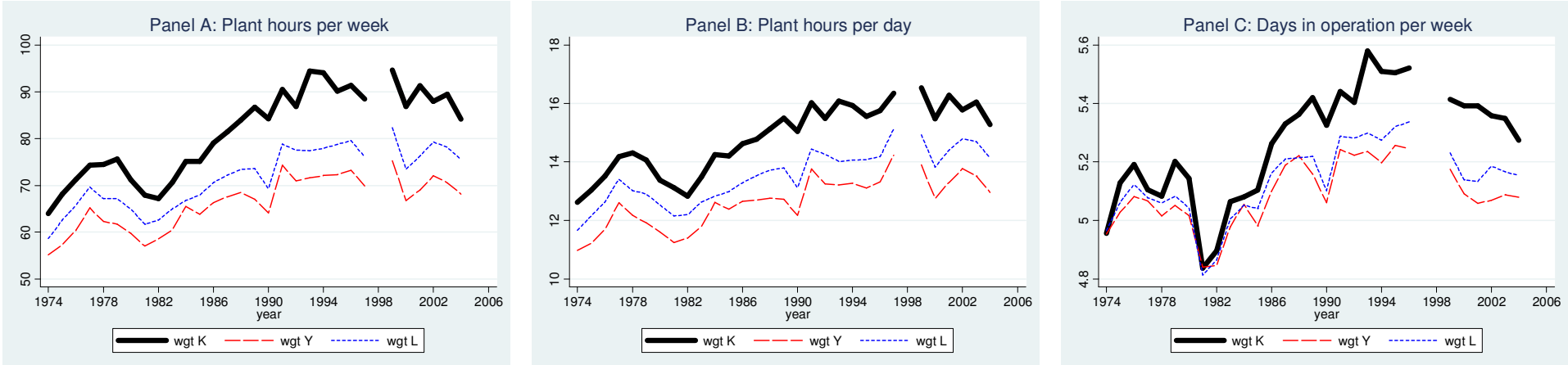

SIC 25: Furniture and fixtures
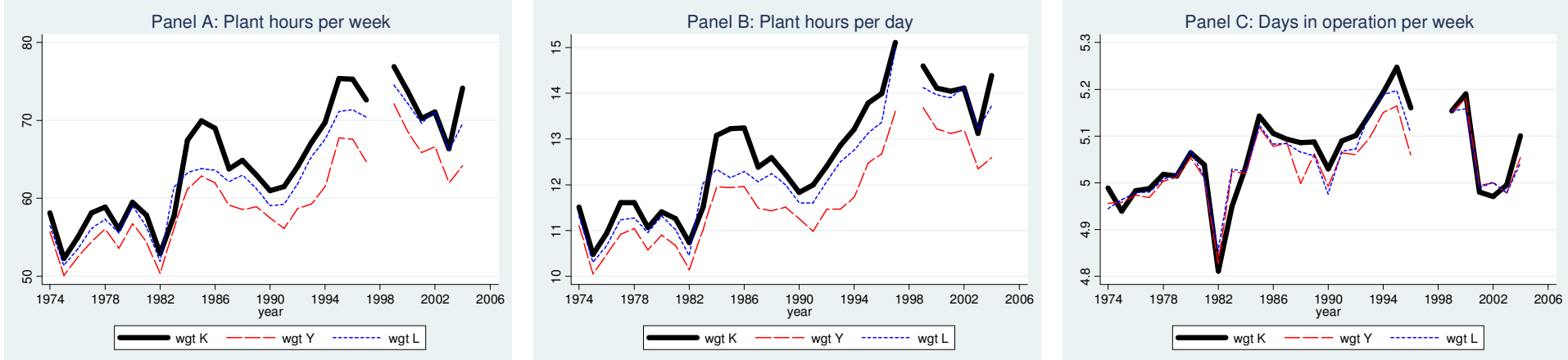

SIC 26: Paper and allied products
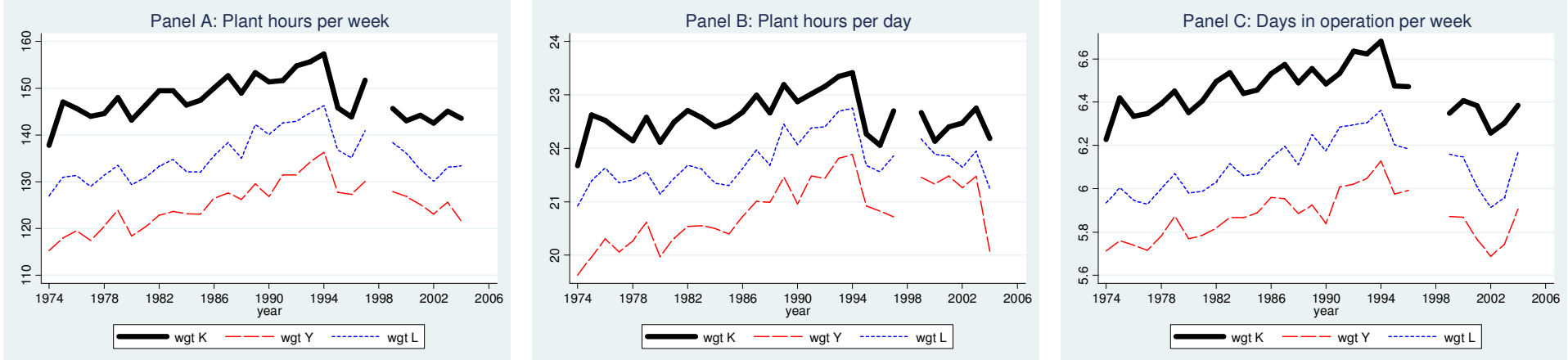

SIC 27: Printing and publishing
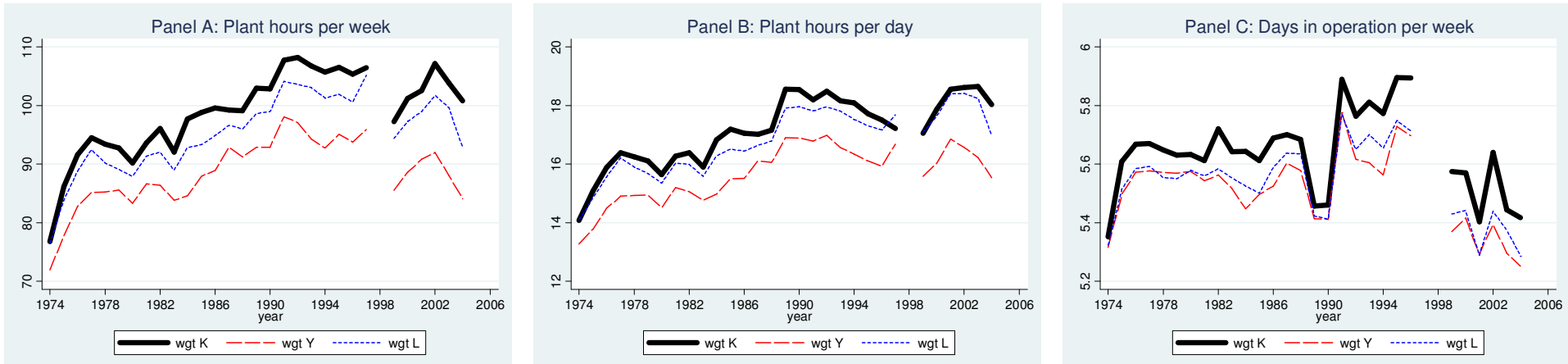

(continued on next page) 
SIC 28: Chemicals and allied products
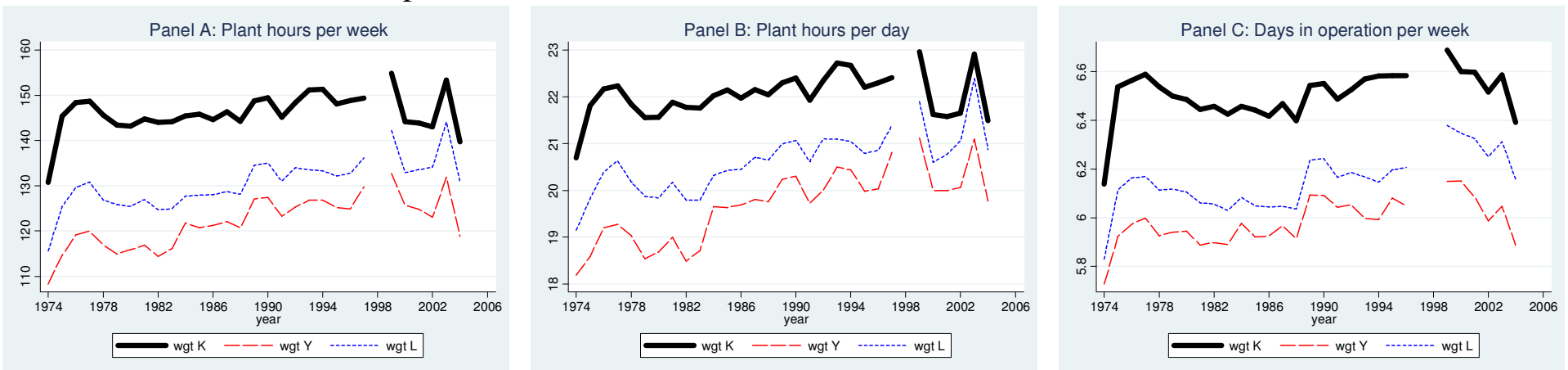

SIC 29: Petroleum and coal products
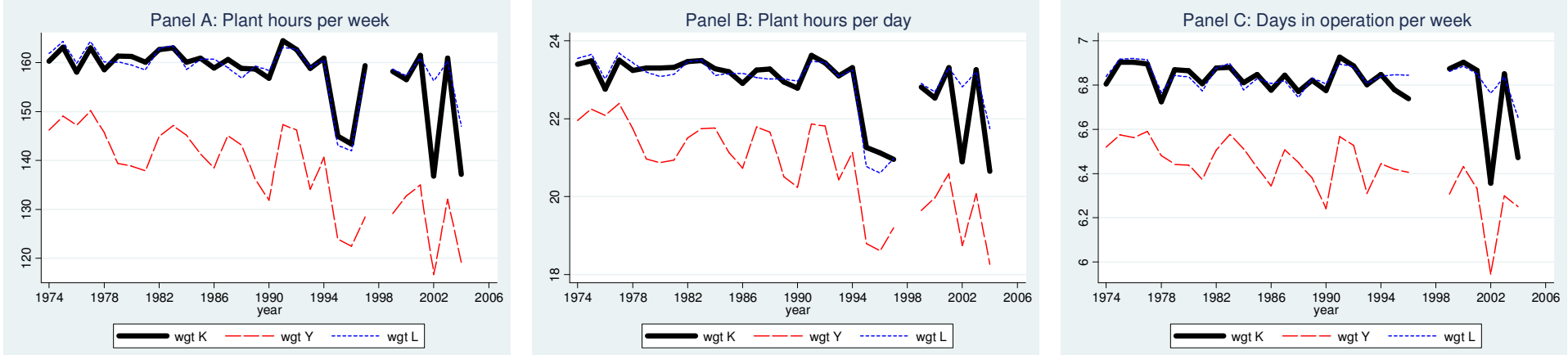

SIC 30: Rubber and miscellaneous plastics products
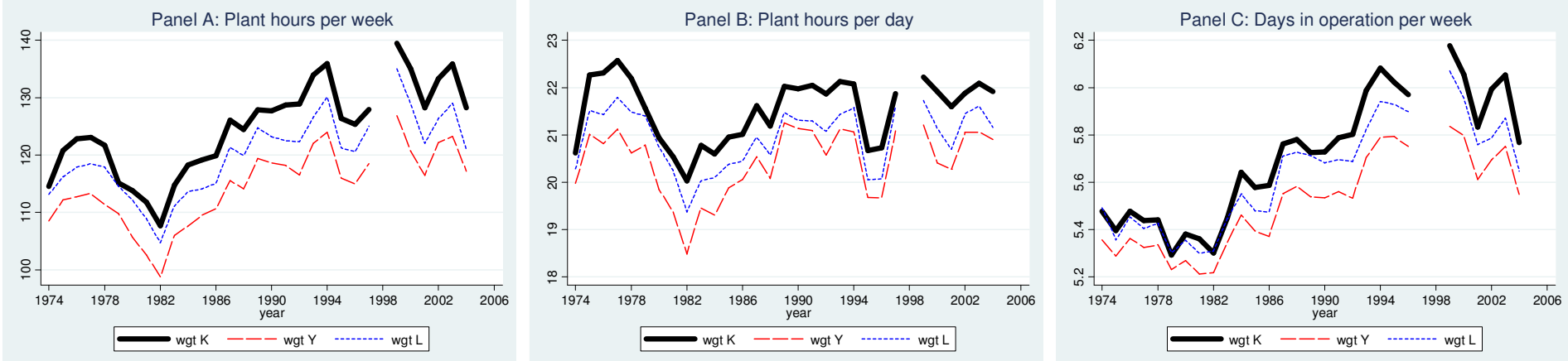

SIC 31: Leather and leather products
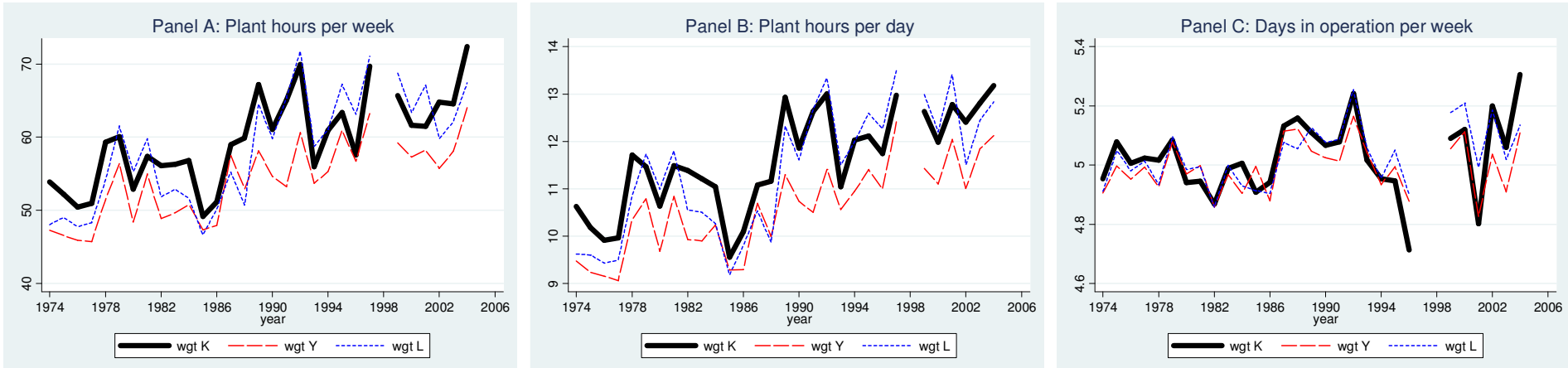

(continued on next page) 
SIC 32: Stone, clay, glass, and concrete products
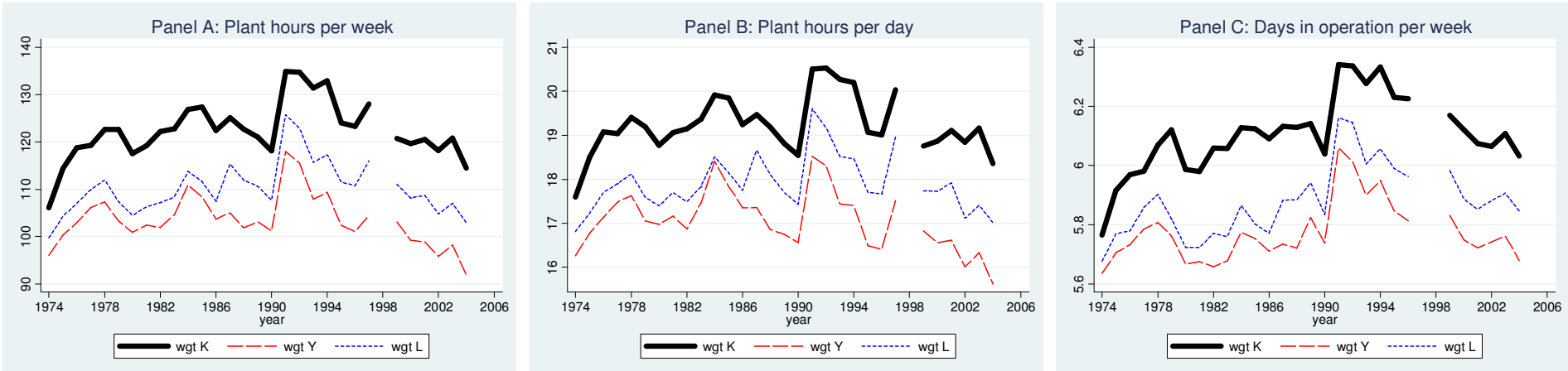

SIC 33: Primary metal industries
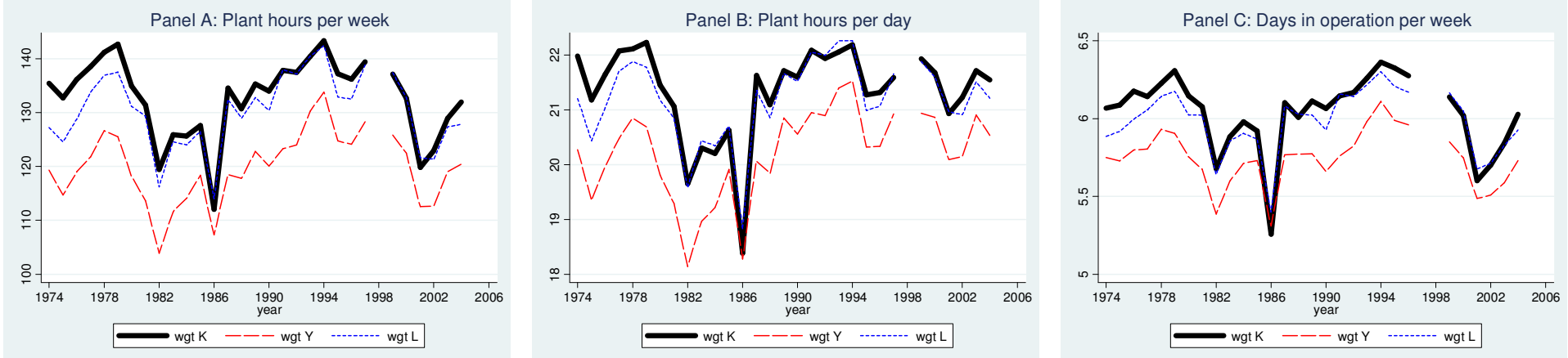

SIC 34: Fabricated metal products
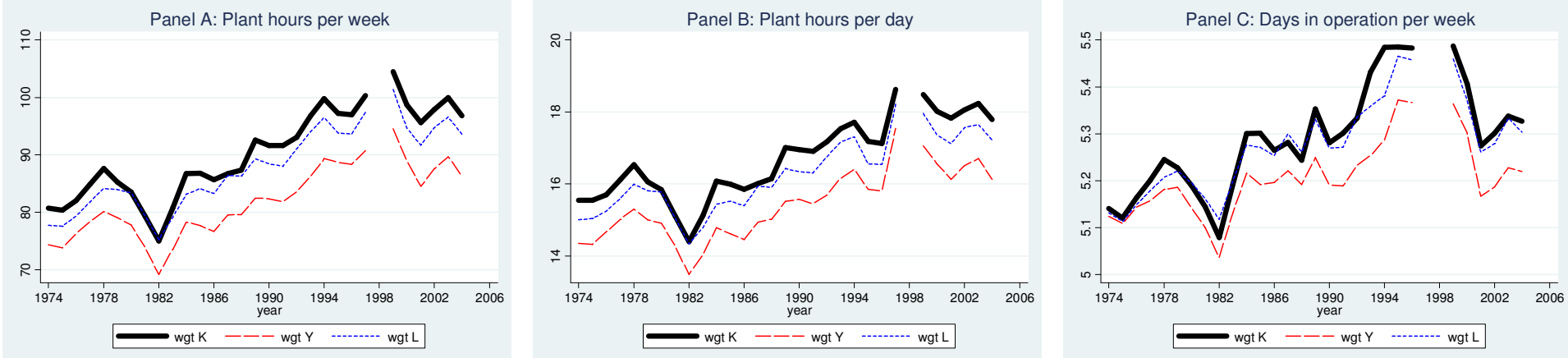

SIC 35: Industrial machinery and equipment
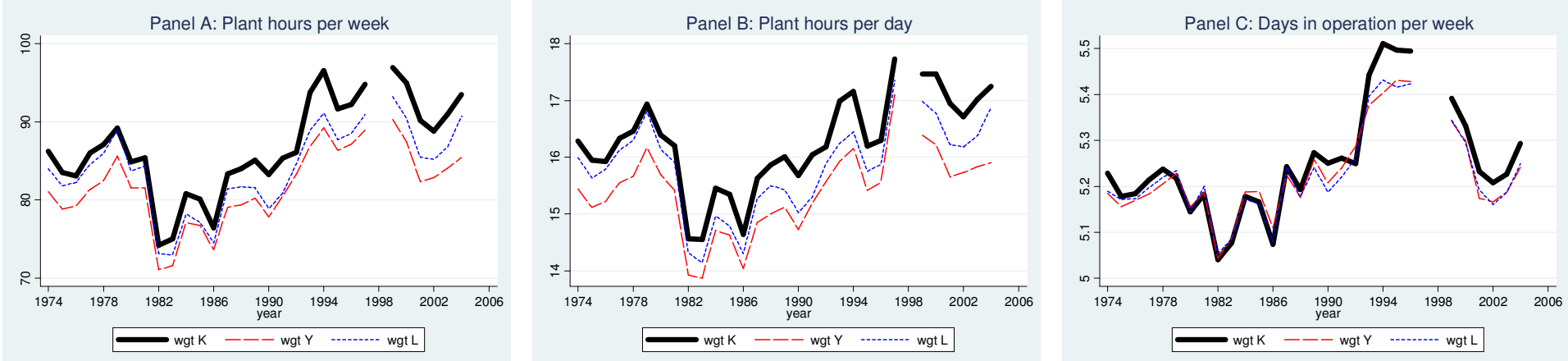

(continued on next page) 
SIC 36: Electrical and electronic equipment
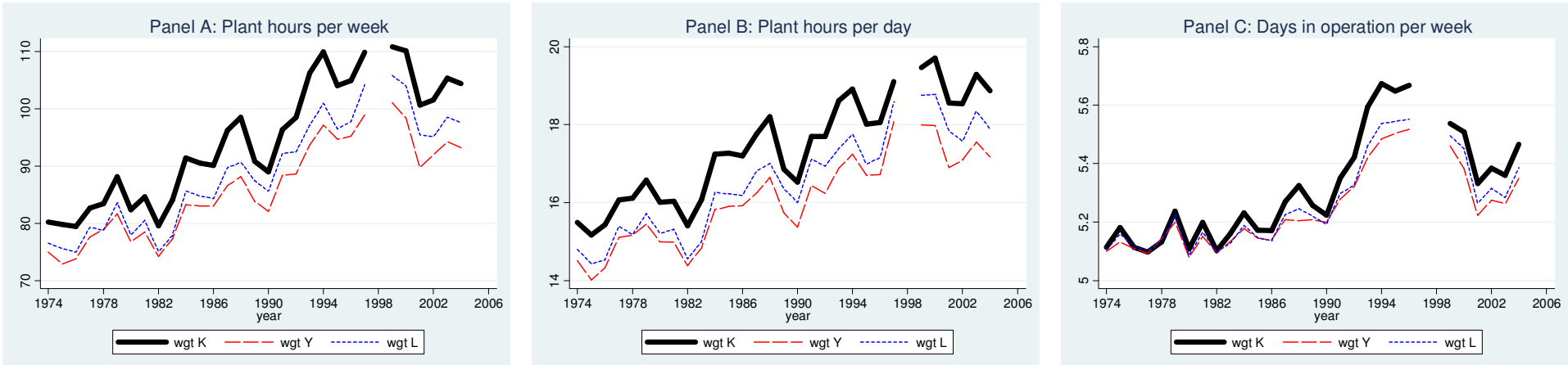

SIC 37: Transportation equipment
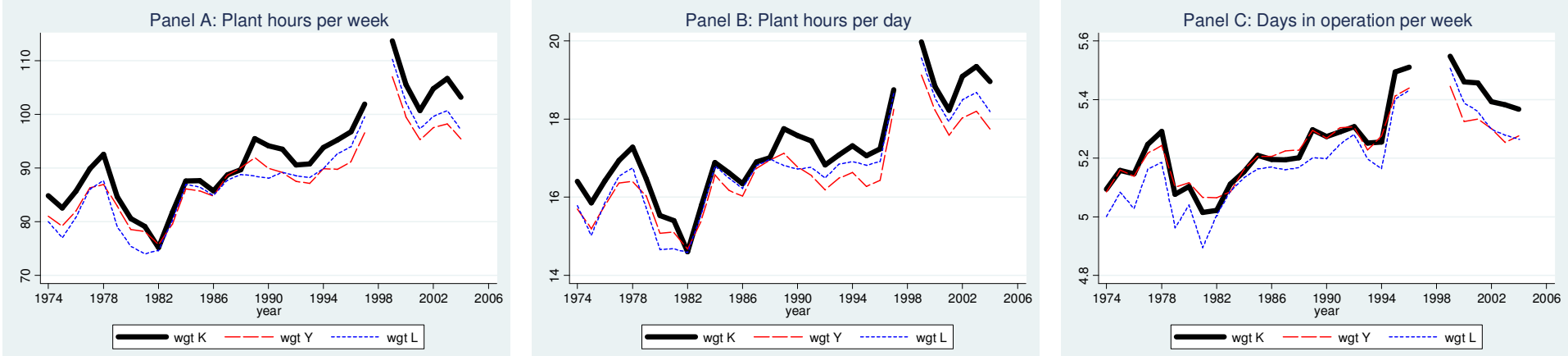

SIC 38: Instruments and related products
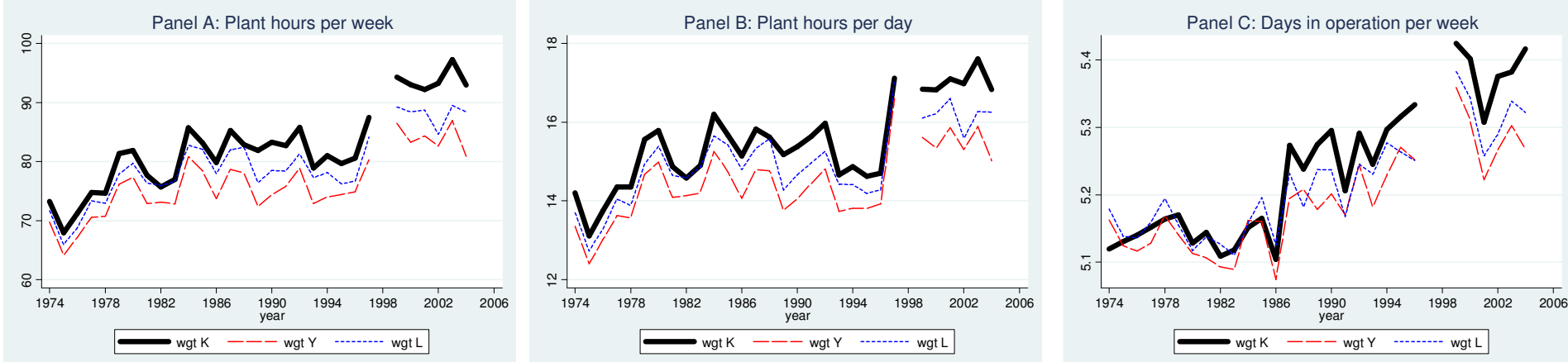

SIC 39: Miscellaneous manufacturing industries
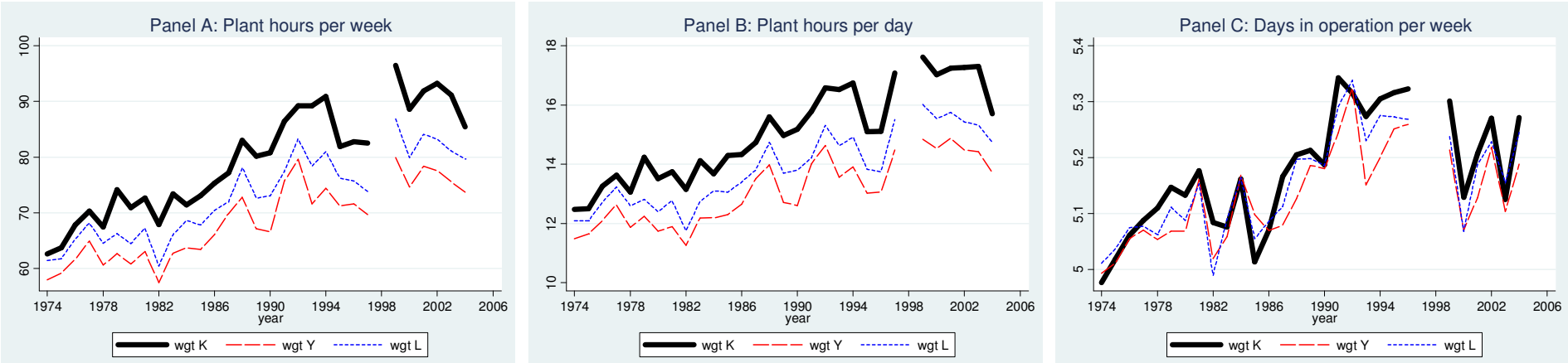

Notes: "weighted by K", "weighted by Y", and "weighted by L" corresponds to capital utilization measure described by capital [eq. (6)], sales [eq. (5)] and employment [eq. (7)] respectively. All series are adjusted for influential observations. Capital is the historical cost of structures and equipment from the most recent Census of Manufactures, sales are from the most recent Census of Manufactures, employment is the number of employee from the most recent Census of Manufactures. Aggregate series of capital utilization is weighted by historical cost of capital. 
Figure 6. Cross correlation of changes in capital utilization and factor inputs.
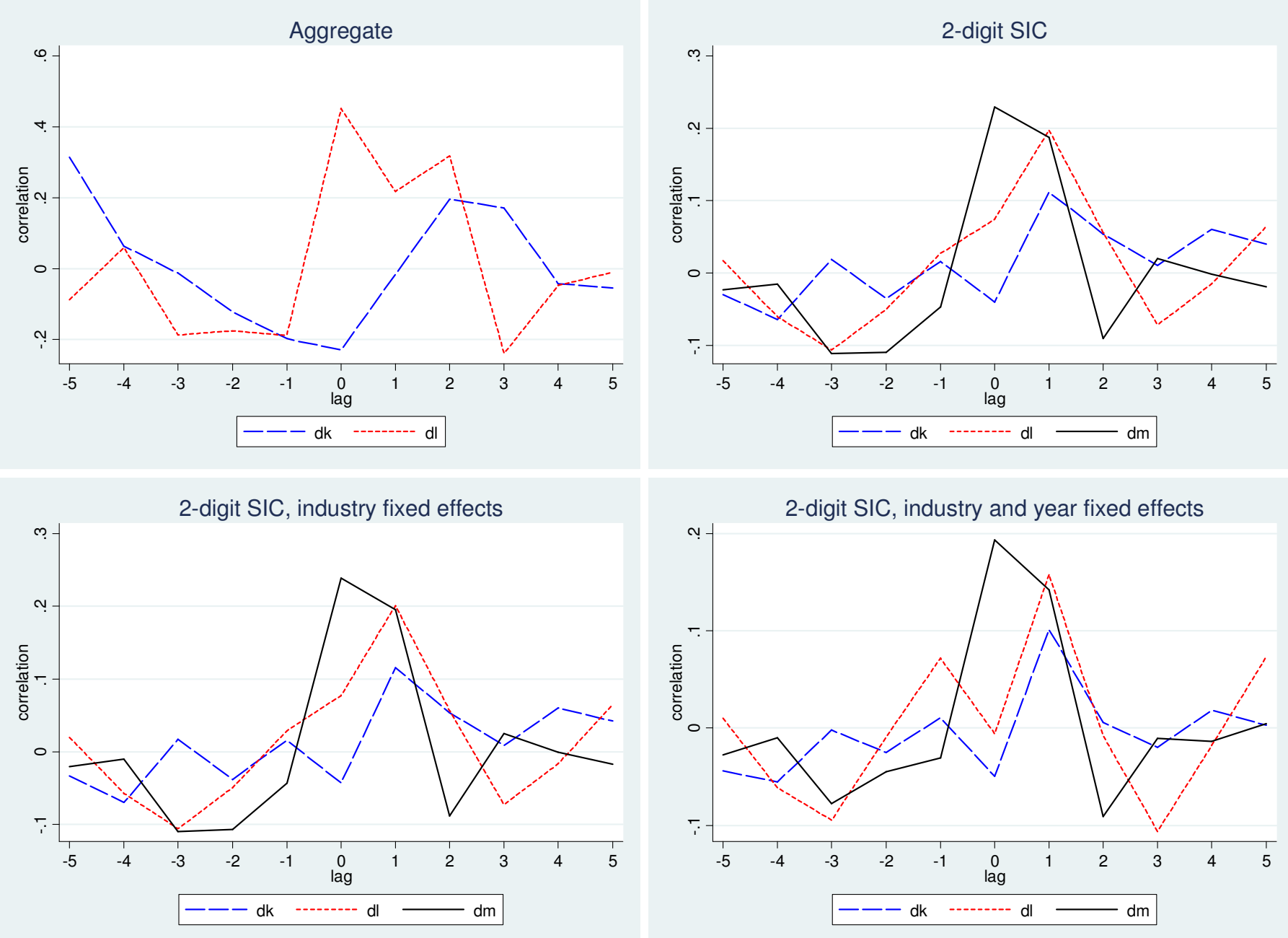

Notes: The figure reports cross correlations of capital utilization (plant hours per week) and capital (dk), labor (dl), materials (dm). The horizontal axis shows $s$ in $\rho\left(\Delta K U_{j t}, d k_{j, t+s}\right), \rho\left(\Delta K U_{j t}, d l_{j, t+s}\right), \rho\left(\Delta K U_{j t}, d m_{j, t+s}\right)$. 
Figure 7. Cross correlation of changes in capital utilization and measures of TFP.
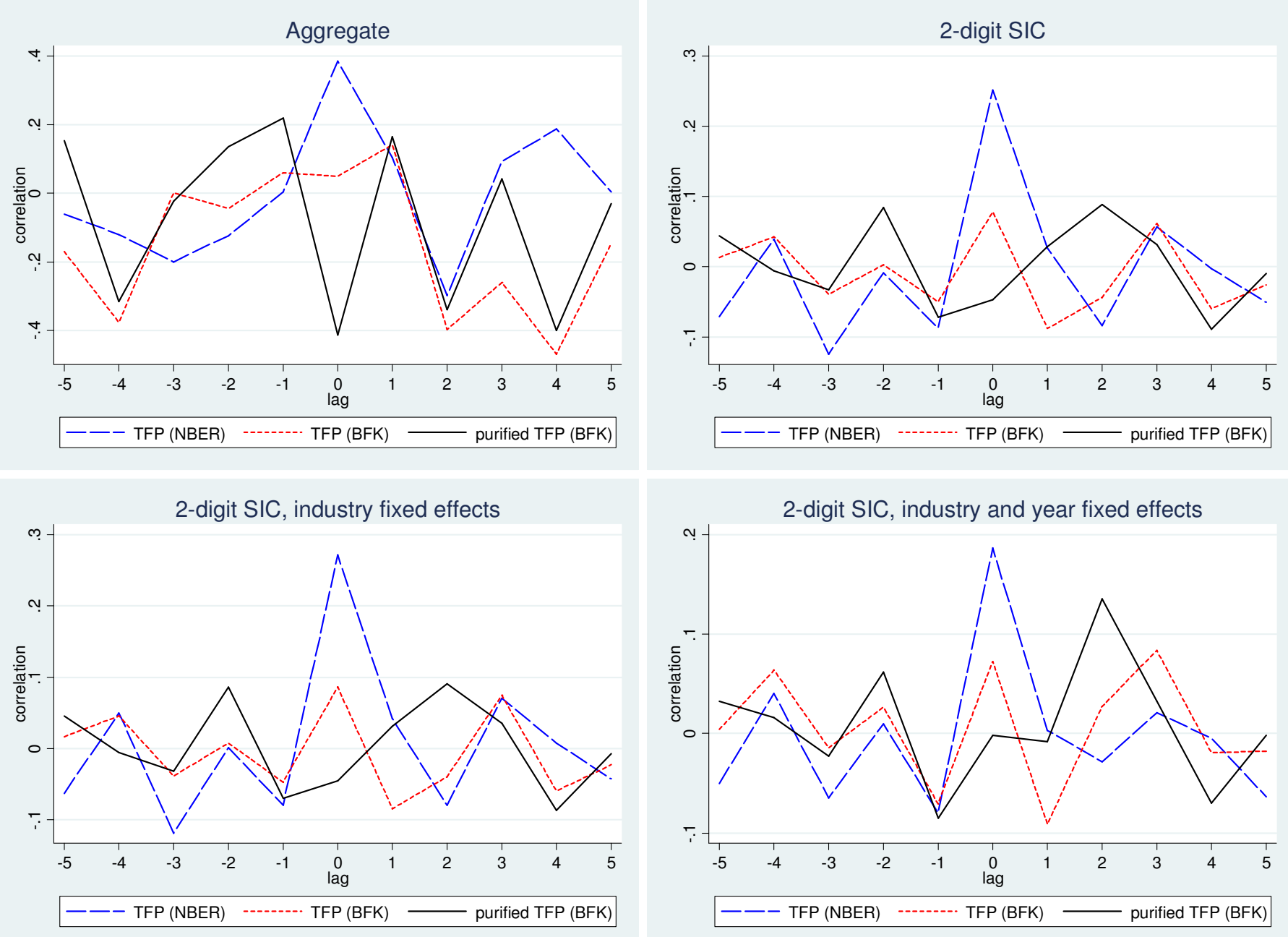

Notes: The figure reports cross correlations of capital utilization (plant hours per week) and measures of TFP. The horizontal axis shows $s$ in $\rho\left(\Delta K U_{j t}, T F P_{j, t+s}\right)$. 
Table 1. Identified trend breaks in capital utilization.

\begin{tabular}{|c|c|c|c|c|c|c|c|c|c|c|}
\hline & \multicolumn{5}{|c|}{ Aggregate series } & \multicolumn{5}{|c|}{ Industry series } \\
\hline & \multirow[b]{2}{*}{ date } & \multicolumn{4}{|c|}{ trend growth, percent per year } & \multirow[b]{2}{*}{ date } & \multicolumn{4}{|c|}{ trend growth, percent per year } \\
\hline & & \multicolumn{2}{|c|}{ before break } & \multicolumn{2}{|c|}{ after break } & & \multicolumn{2}{|c|}{ before break } & \multicolumn{2}{|c|}{ after break } \\
\hline & $(1)$ & $(2)$ & $(3)$ & $(4)$ & $(5)$ & $(6)$ & $(7)$ & $(8)$ & $(9)$ & $(10)$ \\
\hline \multicolumn{11}{|l|}{ Plant hours per week } \\
\hline Simple average & 1997 & 1.711 & $(0.105)$ & -0.203 & $(0.215)$ & 1997 & 1.413 & $(0.131)$ & -0.216 & $(0.435)$ \\
\hline Weighted by output & 1996 & 0.744 & $(0.056)$ & -0.569 & $(0.317)$ & 1996 & 0.821 & $(0.108)$ & -0.464 & $(0.297)$ \\
\hline Weighted by employment & 1991 & 0.785 & $(0.068)$ & -0.558 & $(0.385)$ & 1997 & 0.752 & $(0.103)$ & -0.705 & $(0.261)$ \\
\hline \multicolumn{11}{|l|}{ Plant hours per day } \\
\hline Simple average & 1995 & 1.334 & $(0.088)$ & -0.125 & $(0.179)$ & 1995 & 1.089 & $(0.098)$ & -0.129 & $(0.337)$ \\
\hline Weighted by capital & 1995 & 0.407 & $(0.064)$ & 0.180 & $(0.149)$ & 1995 & 0.576 & $(0.098)$ & 0.339 & $(0.253)$ \\
\hline Weighted by output & 1995 & 0.497 & $(0.051)$ & 0.108 & $(0.285)$ & 1995 & 0.545 & $(0.094)$ & 0.181 & $(0.213)$ \\
\hline Weighted by capital & 1997 & 0.251 & $(0.027)$ & -0.384 & $(0.106)$ & 1997 & 0.282 & $(0.050)$ & -0.442 & $(0.186)$ \\
\hline Weighted by output & 1997 & 0.248 & $(0.019)$ & -0.381 & $(0.089)$ & 1997 & 0.242 & $(0.039)$ & -0.496 & $(0.140)$ \\
\hline Weighted by employment & 1997 & 0.231 & $(0.026)$ & -0.381 & $(0.119)$ & 1997 & 0.216 & $(0.038)$ & -0.406 & $(0.122)$ \\
\hline
\end{tabular}

Notes: the table shows the properties of the break in the trend growth of capital utilization measures. "weighted by capital", "weighted by output", and "weighted by employment" corresponds to capital utilization measure described by capital [eq. (6)], sales [eq. (5)] and employment [eq. (7)] respectively. All series are adjusted for influential observations. Capital is the historical cost of structures and equipment from the most recent Census of Manufactures, sales are from the most recent Census of Manufactures, employment is the number of employee from the most recent Census of Manufactures. Estimated specification is given by equation (8). Columns 6 though 10 include industry fixed effects. Robust standard errors are in parentheses. For industry-level estimates, robust standard errors are clustered by industry. 
Table 2. Raw total factor productivity (BFK) and plant hours per week (PHW).

\begin{tabular}{|c|c|c|c|c|c|c|c|}
\hline \multirow[b]{2}{*}{ Weight variable } & \multicolumn{2}{|c|}{ Aggregate series } & \multicolumn{2}{|c|}{ Industry series, Pooled } & \multicolumn{3}{|c|}{ Industry series, Fixed effects } \\
\hline & $\begin{array}{c}\text { OLS } \\
(1)\end{array}$ & $\begin{array}{l}\text { IV } \\
(2)\end{array}$ & $\begin{array}{c}\text { OLS } \\
(3)\end{array}$ & $\begin{array}{l}\text { IV } \\
(4)\end{array}$ & $\begin{array}{c}\text { OLS } \\
(5) \\
\end{array}$ & $\begin{array}{c}\text { OLS w/ } \\
\text { year effects } \\
(6) \\
\end{array}$ & $\begin{array}{l}\text { IV } \\
(7)\end{array}$ \\
\hline Weighted by capital stock & $\begin{array}{c}0.028 \\
(0.112)\end{array}$ & $\begin{array}{c}0.255 \\
(0.246)\end{array}$ & $\begin{array}{c}0.055^{* * * *} \\
(0.018)\end{array}$ & $\begin{array}{c}0.104 \\
(0.106)\end{array}$ & $\begin{array}{c}0.058 * * * \\
(0.017)\end{array}$ & $\begin{array}{c}0.057 * * * \\
(0.019)\end{array}$ & $\begin{array}{c}0.129 \\
(0.101)\end{array}$ \\
\hline Observations & 27 & 27 & 562 & 562 & 562 & 562 & 562 \\
\hline R-squared & 0.003 & -0.174 & 0.015 & 0.003 & 0.17 & 0.248 & 0.145 \\
\hline 1st F-stat & & 2.203 & & 5.94 & & & 5.781 \\
\hline J-test & & 0.586 & & 0.325 & & & 0.453 \\
\hline Simple average & $\begin{array}{c}0.059 \\
(0.131)\end{array}$ & $\begin{array}{c}-0.053 \\
(0.547)\end{array}$ & $\begin{array}{c}0.014 \\
(0.011)\end{array}$ & $\begin{array}{c}-0.167 \\
(0.203)\end{array}$ & $\begin{array}{c}0.012 \\
(0.011)\end{array}$ & $\begin{array}{c}0.008 \\
(0.013)\end{array}$ & $\begin{array}{c}-0.13 \\
(0.179)\end{array}$ \\
\hline Observations & 27 & 27 & 561 & 561 & 561 & 561 & 561 \\
\hline R-squared & 0.016 & -0.04 & 0.002 & -0.427 & 0.153 & 0.235 & -0.11 \\
\hline 1 st F-stat & & 0.454 & & 1.058 & & & 4.068 \\
\hline $\mathrm{J}$-test & & 0.219 & & 0.599 & & & 0.402 \\
\hline Weighted by output & $\begin{array}{c}0.034 \\
(0.121)\end{array}$ & $\begin{array}{c}0.398 \\
(0.380)\end{array}$ & $\begin{array}{c}0.069 * * * \\
(0.018)\end{array}$ & $\begin{array}{c}0.109 \\
(0.107)\end{array}$ & $\begin{array}{c}0.071 * * * * \\
(0.017)\end{array}$ & $\begin{array}{c}0.075^{* * *} * \\
(0.019)\end{array}$ & $\begin{array}{c}0.134 \\
(0.102)\end{array}$ \\
\hline Observations & 27 & 27 & 561 & 561 & 561 & 561 & 561 \\
\hline R-squared & 0.003 & -0.368 & 0.022 & 0.014 & 0.175 & 0.254 & 0.157 \\
\hline 1st F-stat & & 1.775 & & 5.576 & & & 5.448 \\
\hline J-test & & 0.733 & & 0.363 & & & 0.514 \\
\hline Weighted by employment & $\begin{array}{c}0.125 \\
(0.108)\end{array}$ & $\begin{array}{c}0.342 \\
(0.286)\end{array}$ & $\begin{array}{c}0.071 * * * \\
(0.018)\end{array}$ & $\begin{array}{c}0.112 \\
(0.097)\end{array}$ & $\begin{array}{c}0.074 * * * \\
(0.017)\end{array}$ & $\begin{array}{c}0.074 * * * \\
(0.020)\end{array}$ & $\begin{array}{c}0.131 \\
(0.092)\end{array}$ \\
\hline Observations & 27 & 27 & 562 & 562 & 562 & 562 & 562 \\
\hline R-squared & 0.054 & -0.106 & 0.023 & 0.016 & 0.177 & 0.255 & 0.162 \\
\hline 1st F-stat & & 1.602 & & 6.978 & & & 6.788 \\
\hline $\mathrm{J}$-test & & 0.859 & & 0.422 & & & 0.600 \\
\hline
\end{tabular}

Notes: Dependent variable is the TFP measure from Basu et al. (2006). Regression specification is given by equation (9). IV includes two instrumental variables as in Basu et al. (2006): monetary policy shocks, oil price shocks. " $1{ }^{\text {st }}$ F-stat" is the F-statistic from the first stage regression. "J-test" is the p-value of Hansen's J-test. Weights from Huber robust regression are applied to reduced the influence of extreme values. Robust standard errors are in parentheses. *, **, and *** are significant at 10\%, 5\%, and $1 \%$ respectively. 
Table 3. Raw total factor productivity (BBG) and plant hours per week (PHW).

\begin{tabular}{|c|c|c|c|c|c|c|c|}
\hline \multirow[b]{2}{*}{ Weight variable } & \multicolumn{2}{|c|}{ Aggregate series } & \multicolumn{2}{|c|}{ Industry series, Pooled } & \multicolumn{3}{|c|}{ Industry series, Fixed effects } \\
\hline & $\begin{array}{c}\text { OLS } \\
(1) \\
\end{array}$ & $\begin{array}{l}\text { IV } \\
(2) \\
\end{array}$ & $\begin{array}{c}\text { OLS } \\
(3) \\
\end{array}$ & $\begin{array}{l}\text { IV } \\
(4) \\
\end{array}$ & $\begin{array}{c}\text { OLS } \\
(5) \\
\end{array}$ & $\begin{array}{c}\text { OLS w/ year } \\
\text { effects } \\
(6) \\
\end{array}$ & $\begin{array}{l}\text { IV } \\
(7) \\
\end{array}$ \\
\hline Weighted by capital stock & $\begin{array}{c}0.290 * * \\
(0.126)\end{array}$ & $\begin{array}{l}-0.064 \\
(0.308)\end{array}$ & $\begin{array}{c}0.108 * * * \\
(0.021)\end{array}$ & $\begin{array}{l}0.162^{*} \\
(0.097)\end{array}$ & $\begin{array}{c}0.113 * * * \\
(0.021)\end{array}$ & $\begin{array}{c}0.055^{* * * *} \\
(0.020)\end{array}$ & $\begin{array}{l}0.169^{*} \\
(0.096)\end{array}$ \\
\hline Observations & 25 & 25 & 520 & 520 & 520 & 520 & 520 \\
\hline R-squared & 0.198 & -0.098 & 0.051 & 0.038 & 0.125 & 0.35 & 0.111 \\
\hline 1st F-stat & & 2.632 & & 8.605 & & & 8.262 \\
\hline J-test & & 0.397 & & 0.363 & & & 0.389 \\
\hline Simple average & $\begin{array}{c}0.269 * * * \\
(0.091)\end{array}$ & $\begin{array}{c}-0.293 \\
(0.568)\end{array}$ & $\begin{array}{c}0.044 * * * \\
(0.010)\end{array}$ & $\begin{array}{l}-0.115 \\
(0.173)\end{array}$ & $\begin{array}{c}0.044 * * * \\
(0.010)\end{array}$ & $\begin{array}{c}0.014 \\
(0.010)\end{array}$ & $\begin{array}{l}-0.104 \\
(0.168)\end{array}$ \\
\hline Observations & 25 & 25 & 520 & 520 & 520 & 520 & 520 \\
\hline R-squared & 0.245 & -0.822 & 0.025 & -0.303 & 0.343 & -0.184 & -0.395 \\
\hline 1st F-stat & & 0.894 & & 1.212 & & 1.192 & 4.089 \\
\hline J-test & & 0.617 & & 0.271 & & & 0.223 \\
\hline Weighted by output & $\begin{array}{c}0.442 * * * \\
(0.099)\end{array}$ & $\begin{array}{c}0.264 \\
(0.201)\end{array}$ & $\begin{array}{c}0.136 * * * \\
(0.021)\end{array}$ & $\begin{array}{l}0.168^{*} \\
(0.094)\end{array}$ & $\begin{array}{c}0.142 * * * \\
(0.021)\end{array}$ & $\begin{array}{c}0.086 * * * \\
(0.020)\end{array}$ & $\begin{array}{l}0.176^{*} \\
(0.094)\end{array}$ \\
\hline Observations & 25 & 25 & 520 & 520 & 520 & 520 & 520 \\
\hline R-squared & 0.423 & 0.355 & 0.079 & 0.074 & 0.153 & 0.365 & 0.148 \\
\hline 1st F-stat & & 3.006 & & 7.542 & & & 7.268 \\
\hline J-test & & 0.069 & & 0.488 & & & 0.524 \\
\hline Weighted by employment & $\begin{array}{c}0.450 * * * \\
(0.088)\end{array}$ & $\begin{array}{c}0.142 \\
(0.227)\end{array}$ & $\begin{array}{c}0.147 * * * \\
(0.020)\end{array}$ & $\begin{array}{l}0.168^{*} \\
(0.088)\end{array}$ & $\begin{array}{c}0.153 * * * \\
(0.021)\end{array}$ & $\begin{array}{c}0.093 * * * \\
(0.021)\end{array}$ & $\begin{array}{c}0.174 * * \\
(0.087)\end{array}$ \\
\hline Observations & 25 & 25 & 520 & 520 & 520 & 520 & 520 \\
\hline R-squared & 0.484 & 0.258 & 0.088 & 0.087 & 0.162 & 0.366 & 0.161 \\
\hline 1st F-stat & & 2.32 & & 8.705 & & & 8.391 \\
\hline J-test & & 0.225 & & 0.602 & & & 0.646 \\
\hline
\end{tabular}

Notes: Dependent variable is the TFP measure from NBER productivity dataset (Bartelsman et al., 2000). Regression specification is given by equation (9). IV includes two instrumental variables as in Basu et al. (2006): monetary policy shocks, oil price shocks. " $1{ }^{\text {st }}$ F-stat" is the F-statistic from the first stage regression. "J-test" is the p-value of Hansen's J-test. Weights from Huber robust regression are applied to reduced the influence of extreme values. Robust standard errors are in parentheses. *, **, and *** are significant at $10 \%, 5 \%$, and $1 \%$ respectively. 
Table 4. Purified total factor productivity (BFK) and plant hours per week (PHW).

\begin{tabular}{|c|c|c|c|c|c|c|c|}
\hline \multirow[b]{2}{*}{ Weight variable } & \multicolumn{2}{|c|}{ Aggregate series } & \multicolumn{2}{|c|}{ Industry series, Pooled } & \multicolumn{3}{|c|}{ Industry series, Fixed effects } \\
\hline & $\begin{array}{c}\text { OLS } \\
(1) \\
\end{array}$ & $\begin{array}{l}\text { IV } \\
(2) \\
\end{array}$ & $\begin{array}{l}\text { OLS } \\
(3)\end{array}$ & $\begin{array}{l}\text { IV } \\
(4)\end{array}$ & $\begin{array}{l}\text { OLS } \\
(5)\end{array}$ & $\begin{array}{c}\text { OLS w/ year } \\
\text { effects } \\
(6)\end{array}$ & $\begin{array}{l}\text { IV } \\
(7)\end{array}$ \\
\hline Weighted by capital stock & $\begin{array}{c}-0.249 * * * \\
(0.072)\end{array}$ & $\begin{array}{l}-0.149 \\
(0.258)\end{array}$ & $\begin{array}{c}-0.038^{*} \\
(0.021)\end{array}$ & $\begin{array}{c}0.02 \\
(0.104)\end{array}$ & $\begin{array}{c}-0.036^{*} \\
(0.021)\end{array}$ & $\begin{array}{c}-0.01 \\
(0.024)\end{array}$ & $\begin{array}{c}0.021 \\
(0.104)\end{array}$ \\
\hline Observations & 27 & 27 & 561 & 561 & 561 & 561 & 561 \\
\hline R-squared & 0.219 & 0.184 & 0.006 & -0.009 & 0.021 & 0.174 & 0.007 \\
\hline 1st F-stat & & 2.586 & & 7.629 & & & 7.46 \\
\hline J-test & & 0.23 & & 0.14 & & & 0.162 \\
\hline Simple average & $\begin{array}{l}-0.091 \\
(0.083)\end{array}$ & $\begin{array}{l}-0.564 \\
(0.802)\end{array}$ & $\begin{array}{c}-0.025 * * \\
(0.012)\end{array}$ & $\begin{array}{l}-0.291 \\
(0.276)\end{array}$ & $\begin{array}{c}-0.025^{* *} \\
(0.013)\end{array}$ & $\begin{array}{l}-0.017 \\
(0.013)\end{array}$ & $\begin{array}{l}-0.276 \\
(0.269)\end{array}$ \\
\hline Observations & 27 & 27 & 562 & 562 & 562 & 562 & 562 \\
\hline R-squared & 0.038 & -0.981 & 0.007 & -0.794 & 0.176 & -0.686 & -0.016 \\
\hline 1st F-stat & & 0.425 & & 0.954 & & & 0.942 \\
\hline J-test & & 0.852 & & 0.94 & & & 0.000 \\
\hline Weighted by output & $\begin{array}{c}-0.273 * * * \\
(0.079)\end{array}$ & $\begin{array}{l}-0.026 \\
(0.348)\end{array}$ & $\begin{array}{l}-0.021 \\
(0.021)\end{array}$ & $\begin{array}{c}0.042 \\
(0.116)\end{array}$ & $\begin{array}{l}-0.019 \\
(0.022)\end{array}$ & $\begin{array}{c}0.009 \\
(0.024)\end{array}$ & $\begin{array}{c}0.041 \\
(0.117)\end{array}$ \\
\hline Observations & 27 & 27 & 562 & 562 & 562 & 562 & 562 \\
\hline R-squared & 0.217 & 0.04 & 0.002 & -0.014 & 0.016 & 0.173 & 0.002 \\
\hline 1st F-stat & & 2.005 & & 6.149 & & & 5.912 \\
\hline $\mathrm{J}$-test & & 0.295 & & 0.155 & & & 0.176 \\
\hline Weighted by employment & $\begin{array}{c}-0.178 * * \\
(0.081)\end{array}$ & $\begin{array}{c}0.09 \\
(0.310)\end{array}$ & $\begin{array}{l}-0.024 \\
(0.021)\end{array}$ & $\begin{array}{c}0.045 \\
(0.099)\end{array}$ & $\begin{array}{l}-0.022 \\
(0.022)\end{array}$ & $\begin{array}{c}0.005 \\
(0.024)\end{array}$ & $\begin{array}{c}0.044 \\
(0.100)\end{array}$ \\
\hline Observations & 27 & 27 & 561 & 561 & 561 & 561 & 561 \\
\hline R-squared & 0.109 & -0.138 & 0.002 & -0.017 & 0.017 & 0.173 & 0 \\
\hline 1st F-stat & & 1.682 & & 8.383 & & & 8.122 \\
\hline J-test & & 0.379 & & 0.167 & & & 0.188 \\
\hline
\end{tabular}

Notes: Dependent variable is the TFP measure from Basu et al. (2006). Regression specification is given by equation (9). IV includes two instrumental variables as in Basu et al. (2006): monetary policy shocks, oil price shocks. " 1 st F-stat" is the F-statistic from the first stage regression. "J-test" is the p-value of Hansen's J-test. Weights from Huber robust regression are applied to reduced the influence of extreme values. Robust standard errors are in parentheses. *, **, and *** are significant at 10\%, 5\%, and 1\% respectively. 
Table 5. Total factor productivity and plant hours per week (PHW) by industry.

\begin{tabular}{|c|c|c|c|c|c|c|}
\hline \multirow[b]{2}{*}{ Industry } & \multicolumn{2}{|c|}{ BBG TFP } & \multicolumn{2}{|c|}{ BFK TFP } & \multicolumn{2}{|c|}{ purified BFK TFP } \\
\hline & $\begin{array}{c}\text { OLS } \\
(1) \\
\end{array}$ & $\begin{array}{l}\text { IV } \\
(2) \\
\end{array}$ & $\begin{array}{c}\text { OLS } \\
(3) \\
\end{array}$ & $\begin{array}{l}\text { IV } \\
(4) \\
\end{array}$ & $\begin{array}{c}\text { OLS } \\
(5) \\
\end{array}$ & $\begin{array}{l}\text { IV } \\
(6) \\
\end{array}$ \\
\hline 20 & $\begin{array}{l}-0.132 \\
(0.125)\end{array}$ & $\begin{array}{l}-0.820 \\
(1.610)\end{array}$ & $\begin{array}{l}-0.089 \\
(0.122)\end{array}$ & $\begin{array}{l}-1.314 \\
(2.867)\end{array}$ & $\begin{array}{l}-0.081 \\
(0.147)\end{array}$ & $\begin{array}{c}1.072 \\
(3.660)\end{array}$ \\
\hline 21 & $\begin{array}{c}0.062 \\
(0.074)\end{array}$ & $\begin{array}{l}-0.118 \\
(0.134)\end{array}$ & $\begin{array}{c}0.085 \\
(0.055)\end{array}$ & $\begin{array}{r}0.034 \\
(0.113)\end{array}$ & $\begin{array}{l}-0.244 * * * \\
(0.080)\end{array}$ & $\begin{array}{l}-0.144 \\
(0.148)\end{array}$ \\
\hline 22 & $\begin{array}{l}0.251 * * * \\
(0.067)\end{array}$ & $\begin{array}{l}-0.158 \\
(0.596)\end{array}$ & $\begin{array}{c}0.166^{*} \\
(0.098)\end{array}$ & $\begin{array}{c}-0.235 \\
(0.615)\end{array}$ & $\begin{array}{l}-0.071 \\
(0.138)\end{array}$ & $\begin{array}{c}0.062 \\
(0.565)\end{array}$ \\
\hline 23 & $\begin{array}{l}-0.029 \\
(0.051)\end{array}$ & $\begin{array}{l}-0.114 \\
(0.079)\end{array}$ & $\begin{array}{l}-0.008 \\
(0.033)\end{array}$ & $\begin{array}{r}0.024 \\
(0.092)\end{array}$ & $\begin{array}{c}0.043 \\
(0.055)\end{array}$ & $\begin{array}{l}-0.092 \\
(0.237)\end{array}$ \\
\hline 24 & $\begin{array}{l}-0.008 \\
(0.083)\end{array}$ & $\begin{array}{c}0.072 \\
(0.188)\end{array}$ & $\begin{array}{l}-0.008 \\
(0.111)\end{array}$ & $\begin{array}{c}0.057 \\
(0.181)\end{array}$ & $\begin{array}{c}0.069 \\
(0.118)\end{array}$ & $\begin{array}{c}0.123 \\
(0.178)\end{array}$ \\
\hline 25 & $\begin{array}{l}0.202 * * * \\
(0.059)\end{array}$ & $\begin{array}{c}0.057 \\
(0.165)\end{array}$ & $\begin{array}{l}0.133 * * * \\
(0.043)\end{array}$ & $\begin{array}{c}0.115 \\
(0.343)\end{array}$ & $\begin{array}{c}0.059 \\
(0.057)\end{array}$ & $\begin{array}{c}0.001 \\
(0.343)\end{array}$ \\
\hline 26 & $\begin{array}{c}0.200 \\
(0.150)\end{array}$ & $\begin{array}{c}0.095 \\
(0.860)\end{array}$ & $\begin{array}{l}-0.455^{*} \\
(0.262)\end{array}$ & $\begin{array}{r}0.965 \\
(1.091)\end{array}$ & $\begin{array}{c}0.010 \\
(0.225)\end{array}$ & $\begin{array}{c}2.525 \\
(7.946)\end{array}$ \\
\hline 27 & $\begin{array}{l}-0.091 \\
(0.121)\end{array}$ & $\begin{array}{c}0.027 \\
(0.505)\end{array}$ & $\begin{array}{l}-0.054 \\
(0.107)\end{array}$ & $\begin{array}{l}-0.457 \\
(0.435)\end{array}$ & $\begin{array}{c}0.097 \\
(0.117)\end{array}$ & $\begin{array}{l}-0.326 \\
(0.518)\end{array}$ \\
\hline 28 & $\begin{array}{l}-0.147 \\
(0.224)\end{array}$ & $\begin{array}{l}-0.484 \\
(0.499)\end{array}$ & $\begin{array}{c}0.049 \\
(0.076)\end{array}$ & $\begin{array}{c}0.241 \\
(0.532)\end{array}$ & $\begin{array}{l}-0.107 \\
(0.109)\end{array}$ & $\begin{array}{c}0.157 \\
(0.433)\end{array}$ \\
\hline 29 & $\begin{array}{l}0.497 * * * \\
(0.111)\end{array}$ & $\begin{array}{c}0.229 \\
(0.522)\end{array}$ & $\begin{array}{l}0.175^{* * *} \\
(0.074)\end{array}$ & $\begin{array}{r}0.660 \\
(0.582)\end{array}$ & $\begin{array}{l}-0.141 \\
(0.109)\end{array}$ & $\begin{array}{l}-0.396 \\
(0.661)\end{array}$ \\
\hline 30 & $\begin{array}{l}0.381 * * * \\
(0.083)\end{array}$ & $\begin{array}{c}0.161 \\
(0.229)\end{array}$ & $\begin{array}{c}0.106 \\
(0.083)\end{array}$ & $\begin{array}{r}0.030 \\
(0.191)\end{array}$ & $\begin{array}{l}-0.143 \\
(0.102)\end{array}$ & $\begin{array}{l}-0.089 \\
(0.232)\end{array}$ \\
\hline 31 & $\begin{array}{l}-0.046 \\
(0.040)\end{array}$ & $\begin{array}{l}-0.058 \\
(0.090)\end{array}$ & $\begin{array}{c}0.060 \\
(0.041)\end{array}$ & $\begin{array}{r}0.044 \\
(0.089)\end{array}$ & $\begin{array}{c}0.015 \\
(0.054)\end{array}$ & $\begin{array}{c}0.126 \\
(0.162)\end{array}$ \\
\hline 32 & $\begin{array}{l}-0.153 * \\
(0.089)\end{array}$ & $\begin{array}{c}0.613 \\
(0.651)\end{array}$ & $\begin{array}{l}-0.143^{* *} \\
(0.063)\end{array}$ & $\begin{array}{l}-0.120 \\
(0.264)\end{array}$ & $\begin{array}{l}-0.129 * \\
(0.068)\end{array}$ & $\begin{array}{l}-0.397 \\
(0.365)\end{array}$ \\
\hline 33 & $\begin{array}{l}0.196 * * * \\
(0.063)\end{array}$ & $\begin{array}{l}0.326^{* *} \\
(0.164)\end{array}$ & $\begin{array}{l}-0.075 \\
(0.049)\end{array}$ & $\begin{array}{c}-0.014 \\
(0.140)\end{array}$ & $\begin{array}{l}-0.161^{* *} \\
(0.075)\end{array}$ & $\begin{array}{c}0.022 \\
(0.258)\end{array}$ \\
\hline 34 & $\begin{array}{l}0.268 * * * \\
(0.087)\end{array}$ & $\begin{array}{c}0.071 \\
(0.207)\end{array}$ & $\begin{array}{c}0.126 \\
(0.078)\end{array}$ & $\begin{array}{l}-0.015 \\
(0.170)\end{array}$ & $\begin{array}{l}-0.202 * * \\
(0.102)\end{array}$ & $\begin{array}{l}-0.175 \\
(0.146)\end{array}$ \\
\hline 35 & $\begin{array}{l}0.420 * * * \\
(0.064)\end{array}$ & $\begin{array}{c}0.258 \\
(0.188)\end{array}$ & $\begin{array}{l}0.289 * * * \\
(0.086)\end{array}$ & $\begin{array}{c}0.287 * \\
(0.156)\end{array}$ & $\begin{array}{l}-0.107 \\
(0.092)\end{array}$ & $\begin{array}{c}0.092 \\
(0.191)\end{array}$ \\
\hline 36 & $\begin{array}{l}0.235^{* * * *} \\
(0.061)\end{array}$ & $\begin{array}{l}0.350^{* *} \\
(0.150)\end{array}$ & $\begin{array}{c}0.073 \\
(0.077)\end{array}$ & $\begin{array}{c}0.729 \\
(0.755)\end{array}$ & $\begin{array}{l}-0.150 * * \\
(0.066)\end{array}$ & $\begin{array}{c}0.437 \\
(0.614)\end{array}$ \\
\hline 38 & $\begin{array}{l}0.154 * * * \\
(0.053)\end{array}$ & $\begin{array}{c}0.000 \\
(0.117)\end{array}$ & $\begin{array}{c}0.113 \\
(0.083)\end{array}$ & $\begin{array}{c}0.493 * \\
(0.283)\end{array}$ & $\begin{array}{l}0.193 * * * \\
(0.074)\end{array}$ & $\begin{array}{c}0.429 * \\
(0.239)\end{array}$ \\
\hline 39 & $\begin{array}{l}-0.056 \\
(0.068)\end{array}$ & $\begin{array}{l}-0.359 \\
(0.312)\end{array}$ & $\begin{array}{l}-0.159 * * \\
(0.073)\end{array}$ & $\begin{array}{r}0.040 \\
(0.209)\end{array}$ & $\begin{array}{l}-0.199 * * \\
(0.084)\end{array}$ & $\begin{array}{c}0.075 \\
(0.282)\end{array}$ \\
\hline 371 & $\begin{array}{l}0.323 * * * \\
(0.074)\end{array}$ & $\begin{array}{c}0.247 * \\
(0.126)\end{array}$ & $\begin{array}{l}0.125 * * * \\
(0.035)\end{array}$ & $\begin{array}{c}0.075 \\
(0.065)\end{array}$ & $\begin{array}{l}-0.047 \\
(0.049)\end{array}$ & $\begin{array}{l}-0.073 \\
(0.059)\end{array}$ \\
\hline $372-379$ & $\begin{array}{c}0.017 \\
(0.082)\end{array}$ & $\begin{array}{c}0.517 \\
(0.608)\end{array}$ & $\begin{array}{c}0.128 \\
(0.083)\end{array}$ & $\begin{array}{c}0.289 \\
(0.441)\end{array}$ & $\begin{array}{l}0.215^{* *} \\
(0.096)\end{array}$ & $\begin{array}{c}0.371 \\
(0.359)\end{array}$ \\
\hline cont. process industries & $\begin{array}{l}0.094 * * * \\
(0.022)\end{array}$ & $\begin{array}{c}0.288 \\
(0.194)\end{array}$ & $\begin{array}{l}0.060 * * * \\
(0.019)\end{array}$ & $\begin{array}{c}-0.038 \\
(0.194)\end{array}$ & $\begin{array}{l}-0.024 \\
(0.022)\end{array}$ & $\begin{array}{c}0.091 \\
(0.171)\end{array}$ \\
\hline non-cont. process industries & $\begin{array}{l}0.142 * * \\
(0.065) \\
\end{array}$ & $\begin{array}{l}-1.128 \\
(1.347) \\
\end{array}$ & $\begin{array}{l}-0.031 \\
(0.048) \\
\end{array}$ & $\begin{array}{r}0.707 \\
(1.363) \\
\end{array}$ & $\begin{array}{l}-0.098 \\
(0.061) \\
\end{array}$ & $\begin{array}{l}-1.026 \\
(1.249) \\
\end{array}$ \\
\hline Observations & 520 & 520 & 561 & 561 & 562 & 562 \\
\hline
\end{tabular}

Notes: BFK TFP and purified BFK TFP are productivity measure from Basu et al. (2006). BBG TFP is the productivity measure from NBER productivity dataset (Bartelsman et al., 2000). Regression specification is given by equation (9). IV includes two instrumental variables as in Basu et al. (2006): monetary policy shocks, oil price shocks. " ${ }^{\text {st }}$ F-stat" is the F-statistic from the first stage regression. "J-test" is the p-value of Hansen's J-test. Weights from Huber robust regression are applied to reduced the influence of extreme values. Robust standard errors are in parentheses. *, **, and *** are significant at $10 \%, 5 \%$, and $1 \%$ respectively. 
Table 6. Raw and utilization corrected measures of TFP.

\begin{tabular}{|c|c|c|c|c|c|c|c|}
\hline \multirow[b]{2}{*}{ VARIABLES } & \multicolumn{2}{|c|}{ Aggregate series } & \multicolumn{2}{|c|}{ Industry series, Pooled } & \multicolumn{3}{|c|}{ Industry series, Fixed effects } \\
\hline & $\begin{array}{c}\text { OLS } \\
(1) \\
\end{array}$ & $\begin{array}{l}\text { IV } \\
\text { (2) } \\
\end{array}$ & $\begin{array}{c}\text { OLS } \\
\text { (3) } \\
\end{array}$ & $\begin{array}{l}\text { IV } \\
\text { (4) } \\
\end{array}$ & $\begin{array}{c}\text { OLS } \\
(5) \\
\end{array}$ & $\begin{array}{l}\text { OLS with year fixed effects } \\
\text { (6) }\end{array}$ & $\begin{array}{l}\text { IV } \\
(7) \\
\end{array}$ \\
\hline & \multicolumn{7}{|c|}{ Raw TFP (BBG) } \\
\hline$\Delta \mathrm{X}$ & $\begin{array}{c}0.430 * * * \\
(0.120)\end{array}$ & $\begin{array}{l}-1.199 \\
(4.268)\end{array}$ & $\begin{array}{c}0.186 * * * \\
(0.011)\end{array}$ & $\begin{array}{l}0.365^{*} \\
(0.197)\end{array}$ & $\begin{array}{c}0.187 * * * \\
(0.011)\end{array}$ & $\begin{array}{c}0.141^{* * * *} \\
(0.013)\end{array}$ & $\begin{array}{r}0.405 * * \\
(0.202)\end{array}$ \\
\hline Observations & 30 & 30 & 872 & 788 & 872 & 872 & 788 \\
\hline 1st F-stat & & 0.0701 & & 1.179 & & & 1.289 \\
\hline J-test & & 0.676 & & 0.004 & & & 0.010 \\
\hline \multirow[t]{2}{*}{$\underline{\text { R-squared }}$} & 0.288 & -3.844 & 0.271 & 0.005 & 0.311 & 0.470 & -0.058 \\
\hline & \multicolumn{7}{|c|}{ Utilization corrected TFP (BBG) } \\
\hline$\Delta \mathrm{X}$ & $\begin{array}{c}0.22 \\
(0.157)\end{array}$ & $\begin{array}{l}-0.823 \\
(0.760)\end{array}$ & $\begin{array}{c}0.150 * * * \\
(0.014)\end{array}$ & $\begin{array}{c}0.009 \\
(0.104)\end{array}$ & $\begin{array}{c}0.154 * * * \\
(0.015)\end{array}$ & $\begin{array}{c}0.111^{* * * *} \\
(0.018)\end{array}$ & $\begin{array}{c}0.016 \\
(0.103)\end{array}$ \\
\hline Observations & 25 & 25 & 521 & 521 & 521 & 521 & 521 \\
\hline R-squared & 0.098 & -2.095 & 0.192 & 0.024 & 0.270 & 0.391 & 0.115 \\
\hline 1st F-stat & & 0.795 & & 3.058 & & & 2.964 \\
\hline \multirow[t]{2}{*}{ J-test } & & 0.949 & & 0.591 & & & 0.581 \\
\hline & \multicolumn{7}{|c|}{ Raw TFP (BFK) } \\
\hline$\Delta \mathrm{X}$ & $\begin{array}{c}0.049 \\
(0.122)\end{array}$ & $\begin{array}{c}1.399 \\
(4.657)\end{array}$ & $\begin{array}{c}-0.052 * * * \\
(0.014)\end{array}$ & $\begin{array}{l}-0.048 \\
(0.105)\end{array}$ & $\begin{array}{c}-0.055^{* * * *} \\
(0.014)\end{array}$ & $\begin{array}{c}-0.090 * * * \\
(0.019)\end{array}$ & $\begin{array}{l}-0.013 \\
(0.103)\end{array}$ \\
\hline Observations & 32 & 32 & 560 & 560 & 560 & 560 & 560 \\
\hline R-squared & 0.006 & -4.557 & 0.023 & 0.023 & 0.168 & 0.260 & 0.154 \\
\hline 1st F-stat & & 0.635 & & 3.135 & & & 3.195 \\
\hline \multirow[t]{2}{*}{ J-test } & & 0.0379 & & 0.582 & & & 0.614 \\
\hline & \multicolumn{7}{|c|}{ Utilization corrected TFP (BFK) } \\
\hline$\Delta \mathrm{X}$ & $\begin{array}{l}-0.114 \\
(0.141)\end{array}$ & $\begin{array}{l}-0.372 \\
(0.582)\end{array}$ & $\begin{array}{c}0.003 \\
(0.011)\end{array}$ & $\begin{array}{c}0.077 \\
(0.175)\end{array}$ & $\begin{array}{l}-0.002 \\
(0.011)\end{array}$ & $\begin{array}{c}-0.040 * * * \\
(0.015)\end{array}$ & $\begin{array}{c}0.098 \\
(0.168)\end{array}$ \\
\hline Observations & 27 & 27 & 912 & 828 & 912 & 912 & 828 \\
\hline 1st F-stat & & 0.637 & & 1.654 & & & 1.862 \\
\hline J-test & & 0.608 & & 0.043 & & & 0.065 \\
\hline \multirow[t]{2}{*}{ R-squared } & 0.024 & -0.098 & 0.000 & -0.059 & 0.107 & 0.226 & 0.013 \\
\hline & \multicolumn{7}{|c|}{ Purified TFP (BFK) } \\
\hline$\Delta \mathrm{X}$ & $\begin{array}{c}-0.277 * * * * \\
(0.089)\end{array}$ & $\begin{array}{l}-0.309 \\
(1.125)\end{array}$ & $\begin{array}{c}-0.092 * * * \\
(0.015)\end{array}$ & $\begin{array}{l}-0.267 \\
(0.184)\end{array}$ & $\begin{array}{c}-0.093 * * * \\
(0.015)\end{array}$ & $\begin{array}{c}-0.094 * * * \\
(0.021)\end{array}$ & $\begin{array}{l}-0.260 \\
(0.184)\end{array}$ \\
\hline Observations & 32 & 32 & 559 & 559 & 559 & 559 & 559 \\
\hline 1st F-stat & & 0.998 & & 1.781 & & & 1.758 \\
\hline J-test & & 0.0655 & & 0.862 & & & 0.852 \\
\hline \multirow[t]{2}{*}{ R-squared } & 0.188 & 0.186 & 0.060 & -0.160 & 0.073 & 0.227 & -0.118 \\
\hline & \multicolumn{7}{|c|}{ Utilization corrected purified TFP (BFK) } \\
\hline$\Delta \mathrm{X}$ & $\begin{array}{c}-0.450 * * * \\
(0.141)\end{array}$ & $\begin{array}{l}-0.945 \\
(0.593)\end{array}$ & $\begin{array}{c}-0.055^{* * *} \\
(0.012)\end{array}$ & $\begin{array}{c}0.158 \\
(0.394)\end{array}$ & $\begin{array}{c}-0.055^{* * * *} \\
(0.013)\end{array}$ & $\begin{array}{c}-0.060 * * * \\
(0.017)\end{array}$ & $\begin{array}{c}0.140 \\
(0.372)\end{array}$ \\
\hline Observations & 27 & 27 & 915 & 831 & 915 & 915 & 831 \\
\hline R-squared & 0.236 & -0.049 & 0.022 & -0.319 & 0.028 & 0.154 & -0.245 \\
\hline 1st F-stat & & 0.875 & & 0.476 & & & 0.499 \\
\hline $\mathrm{J}$-test & & 0.717 & & 0.540 & & & 0.618 \\
\hline
\end{tabular}

Notes: BFK TFP and purified BFK TFP are productivity measure from Basu et al. (2006). BBG TFP is the productivity measure from NBER productivity dataset (Bartelsman et al., 2000). Regression specifications are given by equations (11) and (12). Utilization correction is done as in equation (10). IV includes two instrumental variables as in Basu et al. (2006): monetary policy shocks, oil price shocks. " $1{ }^{\text {st }} \mathrm{F}$-stat" is the F-statistic from the first stage regression. "J-test" is the p-value of Hansen's J-test. Weights from Huber robust regression are applied to reduced the influence of extreme values. Robust standard errors are in parentheses. *, $* *$, and $* * *$ are significant at $10 \%, 5 \%$, and $1 \%$ respectively. 
Table 7. Determinants of TFP and capacity utilization at aggregate level.

\begin{tabular}{lcccc}
\hline \hline & $\begin{array}{c}\text { Capacity } \\
\text { utilization } \\
(1)\end{array}$ & $\begin{array}{c}\text { Raw TFP } \\
(\mathrm{BBG})\end{array}$ & $\begin{array}{c}\text { Raw TFP } \\
(\mathrm{BFK})\end{array}$ & $\begin{array}{c}\text { Purified TFP } \\
(\mathrm{BFK})\end{array}$ \\
\hline \hline Capital utilization & 0.094 & 0.099 & $0.109 *$ & -0.093 \\
& $(0.143)$ & $(0.092)$ & $(0.057)$ & $(0.061)$ \\
Hours & $0.499 * * *$ & 0.142 & $-0.41)^{* * *}$ & $-0.402 * * *$ \\
& $(0.152)$ & $(0.121)$ & $(0.051)$ & $(0.087)$ \\
Materials & $0.477 * * *$ & 0.16 & $0.498 * * *$ & $0.433 * *$ \\
& $(0.126)$ & $(0.128)$ & $(0.071)$ & $(0.115)$ \\
Energy & -0.018 & -0.088 & 0.046 & -0.112 \\
& $(0.092)$ & $(0.096)$ & $(0.049)$ & $(0.070)$ \\
\hline Observations & 24 & 25 & 25 & 25 \\
R-squared & 0.928 & 0.563 & 0.724 & 0.486 \\
\hline \hline
\end{tabular}

Notes: BFK TFP and purified BFK TFP are productivity measure from Basu et al. (2006). BBG TFP is the productivity measure from NBER productivity dataset (Bartelsman et al., 2000). Capacity utilization is from Federal Reserve Board (release G.17). Regression specifications are given by equations (13) and (14). All specifications are estimated by OLS. Weights from Huber robust regression are applied to reduced the influence of extreme values. Robust standard errors are in parentheses. $*, * *$, and $* * *$ are significant at $10 \%, 5 \%$, and $1 \%$ respectively. 
Table 8. Determinants of capacity utilization (CU).

\begin{tabular}{|c|c|c|c|c|}
\hline & $\begin{array}{c}\text { Capacity } \\
\text { utilization } \\
(1) \\
\end{array}$ & $\begin{array}{c}\text { TFP } \\
(\mathrm{BBG}) \\
(2) \\
\end{array}$ & $\begin{array}{c}\text { TFP } \\
(\mathrm{BFK}) \\
(3) \\
\end{array}$ & $\begin{array}{c}\text { purified TFP } \\
\text { (BFK) } \\
(4) \\
\end{array}$ \\
\hline & \multicolumn{4}{|c|}{ Panel A: All industries } \\
\hline \multirow[t]{2}{*}{ Capital utilization } & $0.141 * * *$ & $0.038 * *$ & 0.025 & $-0.042 *$ \\
\hline & $(0.026)$ & $(0.018)$ & $(0.020)$ & $(0.023)$ \\
\hline \multirow[t]{2}{*}{ Hours } & $0.308 * * *$ & $0.152 * * *$ & $-0.084 * * *$ & $-0.093 * * *$ \\
\hline & $(0.039)$ & $(0.027)$ & $(0.029)$ & $(0.031)$ \\
\hline \multirow[t]{2}{*}{ Materials } & $0.526 * * *$ & 0.042 & $0.141 * * *$ & $0.086 * * *$ \\
\hline & $(0.036)$ & $(0.029)$ & $(0.029)$ & $(0.027)$ \\
\hline \multirow[t]{2}{*}{ Energy } & 0.038 & 0.004 & -0.019 & -0.017 \\
\hline & $(0.026)$ & $(0.015)$ & $(0.015)$ & $(0.017)$ \\
\hline Observations & 498 & 520 & 519 & 521 \\
\hline \multirow[t]{2}{*}{ R-squared } & 0.783 & 0.27 & 0.068 & 0.033 \\
\hline & \multicolumn{4}{|c|}{ Panel B: Continuous process industries } \\
\hline \multirow[t]{2}{*}{ Capital utilization } & $0.196^{* *}$ & $0.180^{* * *}$ & 0.006 & -0.076 \\
\hline & $(0.085)$ & $(0.061)$ & $(0.055)$ & $(0.065)$ \\
\hline \multirow[t]{2}{*}{ Hours } & $0.433 * * *$ & $0.294 * * *$ & 0.033 & -0.049 \\
\hline & $(0.092)$ & $(0.086)$ & $(0.060)$ & $(0.090)$ \\
\hline \multirow[t]{2}{*}{ Materials } & $0.493 * * *$ & $-0.180 * * *$ & -0.061 & -0.008 \\
\hline & $(0.057)$ & $(0.066)$ & $(0.042)$ & $(0.067)$ \\
\hline \multirow[t]{2}{*}{ Energy } & 0.029 & -0.022 & -0.009 & $-0.126 * *$ \\
\hline & $(0.044)$ & $(0.035)$ & $(0.044)$ & $(0.053)$ \\
\hline Observations & 100 & 100 & 100 & 99 \\
\hline \multirow[t]{2}{*}{$\underline{\mathrm{R} \text {-squared }}$} & 0.781 & 0.256 & 0.781 & 0.194 \\
\hline & Panel & Non-contin & process ind & ustries \\
\hline \multirow[t]{2}{*}{ Capital utilization } & $0.135 * * *$ & 0.025 & 0.025 & 0.025 \\
\hline & $(0.027)$ & $(0.018)$ & $(0.020)$ & $(0.018)$ \\
\hline \multirow[t]{2}{*}{ Hours } & $0.280 * * *$ & $0.145^{* * *}$ & $-0.128 * * *$ & $0.145^{* * *}$ \\
\hline & $(0.044)$ & $(0.028)$ & $(0.029)$ & $(0.028)$ \\
\hline \multirow[t]{2}{*}{ Materials } & $0.546^{* * *}$ & $0.056 *$ & $0.204 * * *$ & $0.056^{*}$ \\
\hline & $(0.044)$ & $(0.031)$ & $(0.028)$ & $(0.031)$ \\
\hline \multirow[t]{2}{*}{ Energy } & 0.035 & 0.017 & -0.023 & 0.017 \\
\hline & $(0.031)$ & $(0.015)$ & $(0.016)$ & $(0.015)$ \\
\hline Observations & 398 & 420 & 422 & 420 \\
\hline R-squared & 0.791 & 0.326 & 0.13 & 0.326 \\
\hline
\end{tabular}

Notes: The dependent variable in column (1) is the capacity utilization from Federal Reserve Board (release G.17). The dependent variable in column (2) is the TFP measure from the NBER productivity dataset (Bartelsman et al., 2000). The dependent variable in column (3) is the TFP measure from Basu et al. (2006). The dependent variable in column (4) is the purified TFP measure from Basu et al. (2006). Changes in hours and materials are from Basu et al. (2006). Changes in energy consumption are from the NBER productivity dataset (Bartelsman et al., 2000). Regression specification is given by equation (14). All regressions are estimated by least squares. Weights from Huber robust regression are applied to reduced the influence of extreme values. Industry fixed effects are included but not reported. Robust standard errors are in parentheses. $*, * *$, and $* * *$ are significant at $10 \%, 5 \%$, and $1 \%$ respectively. 


\section{Appendix A Additional tables and figures}


Appendix Figure1. Aggregation of capital utilization with weighting by alternative measures of capital stock.
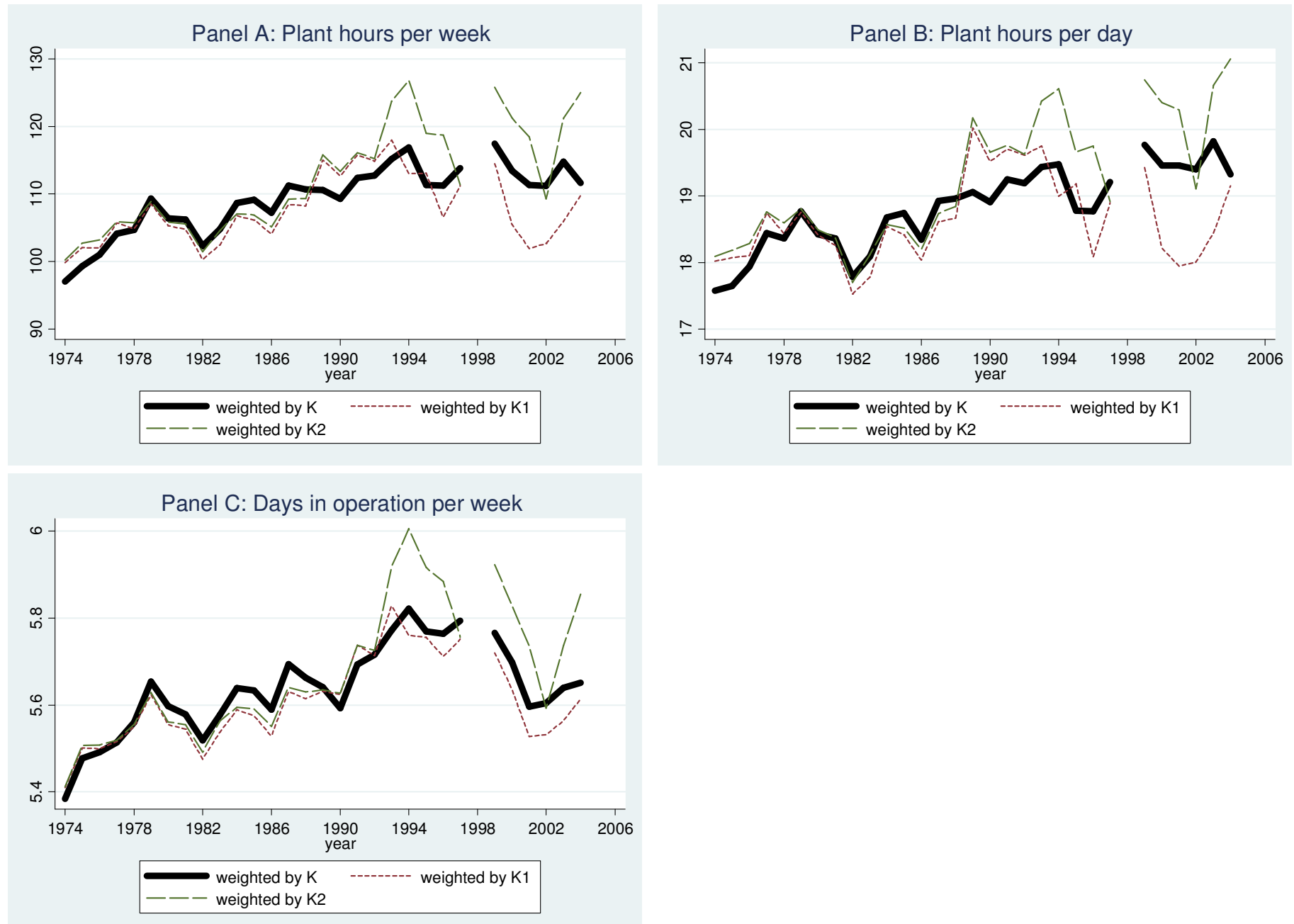

Notes: Weighting scheme corresponds to capital utilization measure described by capital [eq. (6)]. Capital stock $\mathrm{K}$ is the historical cost of structures and equipment in the most recent Census of Manufactures. Capital stock K1 is constructed using perpetual inventory method with imputations for missing investment. Capital stock K2 is constructed using perpetual inventory method with no imputations for missing investment. See appendix for more details on construction of capital stock. All series are adjusted for influential observations. 
Appendix Figure2. Aggregation of capital utilization with weighting by alternative measures of output.
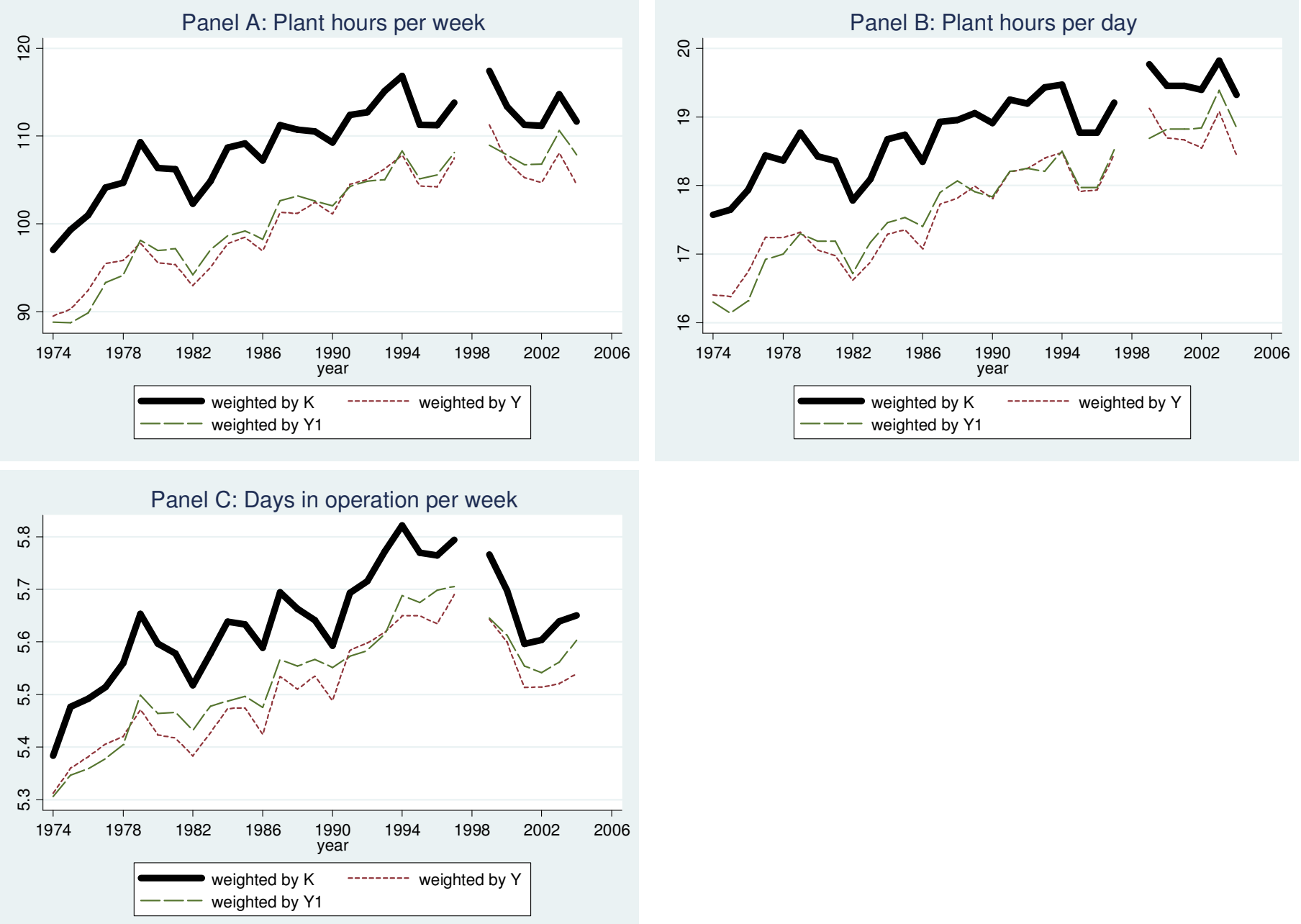

Notes: "weighted by K" and "weighted by Y, Y1" corresponds to capital utilization measure described by capital [eq. (6)] and sales [eq. (5)] respectively. All series are adjusted for influential observations. Capital is the historical cost of structures and equipment. Sales $\mathrm{Y}$ is sales from the most recent Census of Manufactures. Sales $\mathrm{Y}$ is current sales from from SPC. 
Appendix Table A1. Raw total factor productivity (BFK) and plant hours per day (PHD).

\begin{tabular}{|c|c|c|c|c|c|c|c|c|}
\hline \multirow[b]{2}{*}{ Weight variable } & \multicolumn{2}{|c|}{ Aggregate series } & \multicolumn{2}{|c|}{ Industry series, Pooled } & & \multicolumn{3}{|c|}{ Industry series, Fixed effects } \\
\hline & $\begin{array}{c}\text { OLS } \\
(1) \\
\end{array}$ & $\begin{array}{l}\text { IV } \\
(2)\end{array}$ & $\begin{array}{c}\text { OLS } \\
(3) \\
\end{array}$ & $\begin{array}{l}\text { IV } \\
(4)\end{array}$ & & $\begin{array}{c}\text { OLS } \\
(5) \\
\end{array}$ & $\begin{array}{c}\text { OLS w/ yea } \\
\text { effects } \\
(6)\end{array}$ & $\begin{array}{l}\text { IV } \\
(7)\end{array}$ \\
\hline Weighted by capital stock & $\begin{array}{l}-0.034 \\
(0.238)\end{array}$ & $\begin{array}{c}0.979 \\
(1.144)\end{array}$ & $\begin{array}{c}0.063^{* * * *} \\
(0.023)\end{array}$ & $\begin{array}{c}0.09 \\
(0.109)\end{array}$ & & $\begin{array}{c}0.068^{* * * *} \\
(0.021)\end{array}$ & $\begin{array}{c}0.067 * * * \\
(0.023)\end{array}$ & $\begin{array}{c}0.119 \\
(0.103)\end{array}$ \\
\hline Observations & 27 & 27 & 561 & 561 & & 561 & 561 & 561 \\
\hline R-squared & & 0.623 & & 0.262 & & & & 0.342 \\
\hline 1st F-stat & & 0.618 & & 10.78 & & & & 10.49 \\
\hline J-test & 0.001 & -0.569 & 0.013 & 0.01 & & 0.167 & 0.247 & 0.159 \\
\hline Simple average & $\begin{array}{c}0.131 \\
(0.299)\end{array}$ & $\begin{array}{l}-2.837 \\
(8.951)\end{array}$ & $\begin{array}{c}0.01 \\
(0.013)\end{array}$ & $\begin{array}{l}-0.112 \\
(0.143)\end{array}$ & & $\begin{array}{c}0.007 \\
(0.014)\end{array}$ & $\begin{array}{c}0.004 \\
(0.015)\end{array}$ & $\begin{array}{l}-0.074 \\
(0.132)\end{array}$ \\
\hline Observations & 27 & 27 & 561 & 561 & & 561 & 561 & 561 \\
\hline R-squared & & 0.682 & & 0.42 & & & & 0.261 \\
\hline 1st F-stat & & 0.0436 & & 2.398 & & & 2.485 & 3.224 \\
\hline J-test & 0.007 & -3.596 & 0.001 & -0.141 & 0.2 & 0.234 & 0.089 & 0.148 \\
\hline Weighted by output & $\begin{array}{l}-0.028 \\
(0.270)\end{array}$ & $\begin{array}{c}2.033 \\
(3.205)\end{array}$ & $\begin{array}{c}0.085^{* * *} \\
(0.023)\end{array}$ & $\begin{array}{c}0.089 \\
(0.104)\end{array}$ & & $\begin{array}{c}0.088^{* * * *} \\
(0.021)\end{array}$ & $\begin{array}{c}0.091^{* * *} * \\
(0.023)\end{array}$ & $\begin{array}{c}0.117 \\
(0.098)\end{array}$ \\
\hline Observations & 27 & 27 & 560 & 560 & & 560 & 560 & 560 \\
\hline R-squared & & 0.697 & & 0.272 & & & & 0.354 \\
\hline 1st F-stat & & 0.248 & & 10.63 & & & & 10.45 \\
\hline J-test & 0 & -1.492 & 0.022 & 0.022 & & 0.176 & 0.255 & 0.173 \\
\hline Weighted by employment & $\begin{array}{c}0.139 \\
(0.254)\end{array}$ & $\begin{array}{c}1.516 \\
(1.781)\end{array}$ & $\begin{array}{c}0.083 * * * \\
(0.023)\end{array}$ & $\begin{array}{c}0.098 \\
(0.098)\end{array}$ & & $\begin{array}{c}0.088 * * * \\
(0.022)\end{array}$ & $\begin{array}{c}0.087 * * * \\
(0.024)\end{array}$ & $\begin{array}{c}0.121 \\
(0.092)\end{array}$ \\
\hline Observations & 27 & 27 & 562 & 562 & & 562 & 562 & 562 \\
\hline R-squared & & 0.757 & & 0.309 & & & & 0.42 \\
\hline 1st F-stat & & 0.626 & & 12.17 & & & & 11.85 \\
\hline J-test & 0.008 & -0.747 & 0.021 & 0.02 & & 0.175 & 0.254 & 0.172 \\
\hline
\end{tabular}

Notes: Dependent variable is the TFP measure from Basu et al. (2006). Regression specification is given by equation (9). IV includes two instrumental variables as in Basu et al. (2006): monetary policy shocks, oil price shocks. " ${ }^{\text {st }}$ F-stat" is the F-statistic from the first stage regression. "J-test" is the p-value of Hansen's J-test. Weights from Huber robust regression are applied to reduced the influence of extreme values. Robust standard errors are in parentheses. 
Appendix Table A2. Raw total factor productivity (BFK) and plant days in operation (POD).

\begin{tabular}{|c|c|c|c|c|c|c|c|}
\hline \multirow[b]{2}{*}{ Weight variable } & \multicolumn{2}{|c|}{ Aggregate series } & \multicolumn{2}{|c|}{ Industry series, Pooled } & \multicolumn{3}{|c|}{ Industry series, Fixed effects } \\
\hline & $\begin{array}{c}\text { OLS } \\
(1) \\
\end{array}$ & $\begin{array}{l}\text { IV } \\
(2) \\
\end{array}$ & $\begin{array}{c}\text { OLS } \\
(3) \\
\end{array}$ & $\begin{array}{l}\text { IV } \\
(4) \\
\end{array}$ & $\begin{array}{c}\text { OLS } \\
(5) \\
\end{array}$ & $\begin{array}{l}\text { OLS w/ year } \\
\text { effects } \\
(6) \\
\end{array}$ & $\begin{array}{l}\text { IV } \\
(7) \\
\end{array}$ \\
\hline Weighted by capital stock & $\begin{array}{l}-0.034 \\
(0.238)\end{array}$ & $\begin{array}{c}0.979 \\
(1.144)\end{array}$ & $\begin{array}{l}0.085^{*} \\
(0.043)\end{array}$ & $\begin{array}{c}0.493 \\
(0.469)\end{array}$ & $\begin{array}{l}0.085^{*} \\
(0.044)\end{array}$ & $\begin{array}{c}0.076 \\
(0.049)\end{array}$ & $\begin{array}{c}0.565 \\
(0.459)\end{array}$ \\
\hline Observations & 27 & 27 & 561 & 561 & 561 & 561 & 561 \\
\hline R-squared & & 0.623 & 0.006 & -0.135 & 0.159 & 0.238 & -0.035 \\
\hline 1st F-stat & & 0.618 & & 2.368 & & & 2.312 \\
\hline J-test & 0.001 & -0.569 & & 0.57 & & & 0.799 \\
\hline Simple average & $\begin{array}{c}0.131 \\
(0.299)\end{array}$ & $\begin{array}{l}-2.837 \\
(8.951)\end{array}$ & $\begin{array}{c}0.045 \\
(0.032)\end{array}$ & $\begin{array}{l}-0.664 \\
(1.828)\end{array}$ & $\begin{array}{c}0.038 \\
(0.031)\end{array}$ & $\begin{array}{c}0.025 \\
(0.033)\end{array}$ & $\begin{array}{l}-0.106 \\
(1.327)\end{array}$ \\
\hline Observations & 27 & 27 & 561 & 561 & 561 & 561 & 561 \\
\hline R-squared & & 0.682 & 0.003 & -0.667 & 0.153 & 0.234 & 0.126 \\
\hline 1st F-stat & & 0.0436 & & 0.16 & & 0.144 & 2.884 \\
\hline J-test & 0.007 & -3.596 & & 0.4 & & 0.191 & 0.001 \\
\hline Weighted by output & $\begin{array}{c}-0.028 \\
(0.270)\end{array}$ & $\begin{array}{c}2.033 \\
(3.205)\end{array}$ & $\begin{array}{c}0.092 * * \\
(0.047)\end{array}$ & $\begin{array}{c}0.663 \\
(0.609)\end{array}$ & $\begin{array}{l}0.089 * \\
(0.051)\end{array}$ & $\begin{array}{c}0.087 \\
(0.057)\end{array}$ & $\begin{array}{c}0.696 \\
(0.592)\end{array}$ \\
\hline Observations & 27 & 27 & 561 & 561 & 561 & 561 & 561 \\
\hline R-squared & & 0.697 & 0.006 & -0.237 & 0.158 & 0.238 & -0.116 \\
\hline 1st F-stat & & 0.248 & & 1.913 & & & 1.871 \\
\hline J-test & 0 & -1.492 & & 0.863 & & & 0.876 \\
\hline Weighted by employment & $\begin{array}{c}0.139 \\
(0.254)\end{array}$ & $\begin{array}{c}1.516 \\
(1.781)\end{array}$ & $\begin{array}{c}0.139 * * * \\
(0.046)\end{array}$ & $\begin{array}{c}0.63 \\
(0.564)\end{array}$ & $\begin{array}{c}0.133 * * * \\
(0.050)\end{array}$ & $\begin{array}{c}0.129 * * \\
(0.058)\end{array}$ & $\begin{array}{c}0.69 \\
(0.553)\end{array}$ \\
\hline Observations & 27 & 27 & 561 & 561 & 561 & 561 & 561 \\
\hline R-squared & & 0.757 & 0.013 & -0.154 & 0.163 & 0.242 & -0.05 \\
\hline 1st F-stat & & 0.626 & & 2.215 & & & 2.144 \\
\hline J-test & 0.008 & -0.747 & & 0.728 & & & 0.991 \\
\hline
\end{tabular}

Notes: Dependent variable is the TFP measure from Basu et al. (2006). Regression specification is given by equation (9). IV includes two instrumental variables as in Basu et al. (2006): monetary policy shocks, oil price shocks. " $1{ }^{\text {st }}$ F-stat" is the F-statistic from the first stage regression. "J-test" is the p-value of Hansen's J-test. Weights from Huber robust regression are applied to reduced the influence of extreme values. Robust standard errors are in parentheses. 
Appendix Table A3. Raw total factor productivity (BBG) and plant hours per day (PHD).

\begin{tabular}{|c|c|c|c|c|c|c|c|}
\hline \multirow[b]{2}{*}{ Weight variable } & \multicolumn{2}{|c|}{ Aggregate series } & \multicolumn{2}{|c|}{ Industry series, Pooled } & \multicolumn{3}{|c|}{ Industry series, Fixed effects } \\
\hline & $\begin{array}{c}\text { OLS } \\
(1) \\
\end{array}$ & $\begin{array}{l}\text { IV } \\
(2) \\
\end{array}$ & $\begin{array}{c}\text { OLS } \\
(3) \\
\end{array}$ & $\begin{array}{l}\text { IV } \\
(4) \\
\end{array}$ & $\begin{array}{c}\text { OLS } \\
(5) \\
\end{array}$ & $\begin{array}{l}\text { OLS w/ year } \\
\text { effects } \\
(6) \\
\end{array}$ & $\begin{array}{l}\text { IV } \\
\text { (7) }\end{array}$ \\
\hline Weighted by capital stock & $\begin{array}{c}0.326^{* *} \\
(0.145)\end{array}$ & $\begin{array}{c}0.029 \\
(0.258)\end{array}$ & $\begin{array}{c}0.107 * * * * \\
(0.026)\end{array}$ & $\begin{array}{c}0.164 \\
(0.113)\end{array}$ & $\begin{array}{c}0.112 * * * \\
(0.026)\end{array}$ & $\begin{array}{c}0.055^{* *} \\
(0.025)\end{array}$ & $\begin{array}{c}0.172 \\
(0.111)\end{array}$ \\
\hline Observations & 25 & 25 & 520 & 520 & 520 & 520 & 520 \\
\hline R-squared & 0.154 & 0.026 & 0.033 & 0.024 & 0.106 & 0.342 & 0.096 \\
\hline 1st F-stat & & 5.132 & & 12.81 & & & 12.31 \\
\hline J-test & & 0.21 & & 0.219 & & & 0.236 \\
\hline Simple average & $\begin{array}{c}0.256^{* *} \\
(0.113)\end{array}$ & $\begin{array}{c}-0.219 \\
(0.364)\end{array}$ & $\begin{array}{c}0.039 * * * \\
(0.012)\end{array}$ & $\begin{array}{l}-0.072 \\
(0.129)\end{array}$ & $\begin{array}{c}0.039 * * * \\
(0.012)\end{array}$ & $\begin{array}{c}0.01 \\
(0.012)\end{array}$ & $\begin{array}{l}-0.064 \\
(0.127)\end{array}$ \\
\hline Observations & 25 & 25 & 520 & 520 & 520 & 520 & 520 \\
\hline R-squared & 0.148 & -0.361 & 0.015 & -0.104 & 0.087 & 0.339 & -0.014 \\
\hline 1st F-stat & & 1.662 & & 2.578 & & & 3.16 \\
\hline J-test & & 0.848 & & 0.172 & & & 4.49E-06 \\
\hline Weighted by output & $\begin{array}{c}0.462 * * * \\
(0.157)\end{array}$ & $\begin{array}{c}0.163 \\
(0.255)\end{array}$ & $\begin{array}{c}0.142 * * * \\
(0.026)\end{array}$ & $\begin{array}{c}0.169 \\
(0.104)\end{array}$ & $\begin{array}{c}0.146^{* * * *} \\
(0.025)\end{array}$ & $\begin{array}{c}0.092 * * * \\
(0.025)\end{array}$ & $\begin{array}{l}0.177 * \\
(0.102)\end{array}$ \\
\hline Observations & 25 & 25 & 520 & 520 & 520 & 520 & 520 \\
\hline R-squared & 0.26 & 0.151 & 0.059 & 0.057 & 0.132 & 0.357 & 0.13 \\
\hline 1st F-stat & & 6.267 & & 12.08 & & & 11.93 \\
\hline J-test & & 0.209 & & 0.268 & & & 0.284 \\
\hline Weighted by employment & $\begin{array}{c}0.478 * * * * \\
(0.130)\end{array}$ & $\begin{array}{c}0.115 \\
(0.246)\end{array}$ & $\begin{array}{c}0.148^{* * * *} \\
(0.025)\end{array}$ & $\begin{array}{l}0.181^{*} \\
(0.099)\end{array}$ & $\begin{array}{c}0.155^{* * * *} \\
(0.025)\end{array}$ & $\begin{array}{c}0.092 * * * \\
(0.025)\end{array}$ & $\begin{array}{l}0.189^{*} \\
(0.098)\end{array}$ \\
\hline Observations & 25 & 25 & 520 & 520 & 520 & 520 & 520 \\
\hline R-squared & 0.34 & 0.144 & 0.063 & 0.06 & 0.136 & 0.356 & 0.133 \\
\hline 1st F-stat & & 4.835 & & 13.03 & & & 12.72 \\
\hline J-test & & 0.259 & & 0.347 & & & 0.372 \\
\hline
\end{tabular}

Notes: Dependent variable is the TFP measure from NBER productivity dataset (Bartelsman et al., 2000). Regression specification is given by equation (9). IV includes two instrumental variables as in Basu et al. (2006): monetary policy shocks, oil price shocks. " $1{ }^{\text {st }}$ F-stat" is the F-statistic from the first stage regression. "J-test" is the p-value of Hansen's J-test. Weights from Huber robust regression are applied to reduced the influence of extreme values. Robust standard errors are in parentheses. 
Appendix Table A4. Raw total factor productivity (BBG) and plant days in operation (POD).

\begin{tabular}{|c|c|c|c|c|c|c|c|}
\hline \multirow[b]{2}{*}{ Weight variable } & \multicolumn{2}{|c|}{ Aggregate series } & \multicolumn{2}{|c|}{ Industry series, Pooled } & \multicolumn{3}{|c|}{ Industry series, Fixed effects } \\
\hline & $\begin{array}{c}\text { OLS } \\
(1) \\
\end{array}$ & $\begin{array}{l}\text { IV } \\
(2) \\
\end{array}$ & $\begin{array}{c}\text { OLS } \\
(3) \\
\end{array}$ & $\begin{array}{l}\text { IV } \\
(4) \\
\end{array}$ & $\begin{array}{c}\text { OLS } \\
(5) \\
\end{array}$ & $\begin{array}{l}\text { OLS w/ year } \\
\text { effects } \\
(6) \\
\end{array}$ & $\begin{array}{l}\text { IV } \\
(7) \\
\end{array}$ \\
\hline Weighted by capital stock & $\begin{array}{c}1.110 * * * \\
(0.277)\end{array}$ & $\begin{array}{l}-0.054 \\
(1.549)\end{array}$ & $\begin{array}{c}0.303 * * * \\
(0.055)\end{array}$ & $\begin{array}{l}0.548^{*} \\
(0.304)\end{array}$ & $\begin{array}{c}0.306 * * * \\
(0.054)\end{array}$ & $\begin{array}{c}0.176 * * * \\
(0.056)\end{array}$ & $\begin{array}{l}0.562 * \\
(0.300)\end{array}$ \\
\hline Observations & 25 & 25 & 521 & 521 & 521 & 521 & 521 \\
\hline R-squared & 0.473 & -0.047 & 0.064 & 0.022 & 0.135 & 0.359 & 0.089 \\
\hline 1st F-stat & & 0.244 & & 4.369 & & & 4.26 \\
\hline J-test & & 0.548 & & 0.767 & & & 0.821 \\
\hline Simple average & $\begin{array}{c}0.563 * * \\
(0.246)\end{array}$ & $\begin{array}{l}-2.167 \\
(8.032)\end{array}$ & $\begin{array}{c}0.158 * * * \\
(0.041)\end{array}$ & $\begin{array}{c}0.181 \\
(0.777)\end{array}$ & $\begin{array}{c}0.154 * * * \\
(0.043)\end{array}$ & $\begin{array}{c}0.089 * * \\
(0.041)\end{array}$ & $\begin{array}{c}0.3 \\
(0.771)\end{array}$ \\
\hline Observations & 25 & 25 & 520 & 520 & 520 & 520 & 520 \\
\hline R-squared & 0.118 & -2.654 & 0.031 & 0.03 & 0.348 & 0.074 & -0.155 \\
\hline 1st F-stat & & 0.845 & & 0.515 & & & 0.488 \\
\hline J-test & & 0.0582 & & 0.122 & & 0.126 & 0.000 \\
\hline Weighted by output & $\begin{array}{c}1.471 * * * \\
(0.282)\end{array}$ & $\begin{array}{l}-0.045 \\
(2.846)\end{array}$ & $\begin{array}{c}0.384 * * * \\
(0.059)\end{array}$ & $\begin{array}{l}0.657 * \\
(0.387)\end{array}$ & $\begin{array}{c}0.383 * * * \\
(0.058)\end{array}$ & $\begin{array}{c}0.250 * * * \\
(0.064)\end{array}$ & $\begin{array}{l}0.681 * \\
(0.382)\end{array}$ \\
\hline Observations & 25 & 25 & 522 & 522 & 522 & 522 & 522 \\
\hline R-squared & 0.53 & -0.033 & 0.089 & 0.045 & 0.16 & 0.371 & 0.107 \\
\hline 1st F-stat & & 0.26 & & 3.037 & & & 2.976 \\
\hline J-test & & 0.209 & & 0.984 & & & 0.951 \\
\hline Weighted by employment & $\begin{array}{c}1.669 * * * \\
(0.185)\end{array}$ & $\begin{array}{l}1.479 * * \\
(0.722)\end{array}$ & $\begin{array}{c}0.440 * * * \\
(0.061)\end{array}$ & $\begin{array}{l}0.575^{*} \\
(0.324)\end{array}$ & $\begin{array}{c}0.442 * * * \\
(0.063)\end{array}$ & $\begin{array}{c}0.295 * * * \\
(0.069)\end{array}$ & $\begin{array}{l}0.595^{*} \\
(0.319)\end{array}$ \\
\hline Observations & 25 & 25 & 521 & 521 & 521 & 521 & 521 \\
\hline R-squared & 0.76 & 0.75 & 0.107 & 0.097 & 0.175 & 0.379 & 0.162 \\
\hline 1st F-stat & & 0.19 & & 4.868 & & & 4.815 \\
\hline J-test & & 0.339 & & 0.975 & & & 0.937 \\
\hline
\end{tabular}

Notes: Dependent variable is the TFP measure from NBER productivity dataset (Bartelsman et al., 2000). Regression specification is given by equation (9). IV includes two instrumental variables as in Basu et al. (2006): monetary policy shocks, oil price shocks. " $1^{\text {st }}$ F-stat" is the F-statistic from the first stage regression. "J-test" is the p-value of Hansen's J-test. Weights from Huber robust regression are applied to reduced the influence of extreme values. Robust standard errors are in parentheses. 
Appendix Table A5. Purified total factor productivity (BFK) and plant hours per day (PHD).

\begin{tabular}{|c|c|c|c|c|c|c|c|}
\hline \multirow[b]{2}{*}{ Weight variable } & \multicolumn{2}{|c|}{ Aggregate series } & \multicolumn{2}{|c|}{ Industry series, Pooled } & \multicolumn{3}{|c|}{ Industry series, Fixed effects } \\
\hline & $\begin{array}{c}\text { OLS } \\
(1) \\
\end{array}$ & $\begin{array}{l}\text { IV } \\
(2) \\
\end{array}$ & $\begin{array}{c}\text { OLS } \\
(3) \\
\end{array}$ & $\begin{array}{l}\text { IV } \\
(4) \\
\end{array}$ & $\begin{array}{c}\text { OLS } \\
(5) \\
\end{array}$ & $\begin{array}{c}\text { OLS w/ year } \\
\text { effects } \\
(6) \\
\end{array}$ & $\begin{array}{l}\text { IV } \\
(7) \\
\end{array}$ \\
\hline Weighted by capital stock & $\begin{array}{c}-0.298 * * \\
(0.108)\end{array}$ & $\begin{array}{l}-0.118 \\
(0.288)\end{array}$ & $\begin{array}{l}-0.024 \\
(0.024)\end{array}$ & $\begin{array}{c}0.006 \\
(0.120)\end{array}$ & $\begin{array}{l}-0.021 \\
(0.025)\end{array}$ & $\begin{array}{c}0.009 \\
(0.028)\end{array}$ & $\begin{array}{c}0.006 \\
(0.120)\end{array}$ \\
\hline Observations & 27 & 27 & 561 & 561 & 561 & 561 & 561 \\
\hline R-squared & 0.164 & 0.105 & 0.002 & -0.001 & 0.016 & 0.173 & 0.014 \\
\hline 1st F-stat & & 5.533 & & 9.806 & & & 9.591 \\
\hline J-test & & 0.285 & & 0.133 & & & 0.156 \\
\hline Simple average & $\begin{array}{l}-0.122 \\
(0.096)\end{array}$ & $\begin{array}{l}-0.395 \\
(0.438)\end{array}$ & $\begin{array}{l}-0.025^{*} \\
(0.014)\end{array}$ & $\begin{array}{l}-0.229 \\
(0.187)\end{array}$ & $\begin{array}{l}-0.026^{*} \\
(0.015)\end{array}$ & $\begin{array}{c}-0.013 \\
(0.016)\end{array}$ & $\begin{array}{l}-0.218 \\
(0.184)\end{array}$ \\
\hline Observations & 27 & 27 & 562 & 562 & 562 & 562 & 562 \\
\hline R-squared & 0.046 & -0.184 & 0.005 & -0.335 & 0.02 & 0.174 & -0.282 \\
\hline 1st F-stat & & 1.687 & & 2.335 & & 2.3 & 3.009 \\
\hline J-test & & 0.507 & & 0.701 & & 0.718 & $1.87 \mathrm{E}-07$ \\
\hline Weighted by output & $\begin{array}{c}-0.287 * * * \\
(0.098)\end{array}$ & $\begin{array}{c}0.004 \\
(0.335)\end{array}$ & $\begin{array}{l}-0.013 \\
(0.025)\end{array}$ & $\begin{array}{c}0.017 \\
(0.124)\end{array}$ & $\begin{array}{l}-0.011 \\
(0.025)\end{array}$ & $\begin{array}{c}0.02 \\
(0.030)\end{array}$ & $\begin{array}{c}0.017 \\
(0.125)\end{array}$ \\
\hline Observations & 27 & 27 & 562 & 562 & 562 & 562 & 562 \\
\hline R-squared & 0.154 & -0.004 & 0 & -0.002 & 0.015 & 0.173 & 0.013 \\
\hline 1st F-stat & & 4.694 & & 8.506 & & & 8.279 \\
\hline J-test & & 0.318 & & 0.136 & & & 0.158 \\
\hline Weighted by employment & $\begin{array}{l}-0.192 * \\
(0.108)\end{array}$ & $\begin{array}{c}0.055 \\
(0.321)\end{array}$ & $\begin{array}{l}-0.016 \\
(0.025)\end{array}$ & $\begin{array}{c}0.024 \\
(0.107)\end{array}$ & $\begin{array}{l}-0.013 \\
(0.026)\end{array}$ & $\begin{array}{c}0.019 \\
(0.029)\end{array}$ & $\begin{array}{c}0.024 \\
(0.108)\end{array}$ \\
\hline Observations & 27 & 27 & 562 & 562 & 562 & 562 & 562 \\
\hline R-squared & 0.075 & -0.05 & 0.001 & -0.004 & 0.015 & 0.173 & 0.012 \\
\hline 1st F-stat & & 3.514 & & 12.38 & & & 12 \\
\hline J-test & & 0.351 & & 0.14 & & & 0.162 \\
\hline
\end{tabular}

Notes: Dependent variable is the TFP measure from NBER productivity dataset (Bartelsman et al., 2000). Regression specification is given by equation (9). IV includes two instrumental variables as in Basu et al. (2006): monetary policy shocks, oil price shocks. " $1^{\text {st }}$ F-stat" is the F-statistic from the first stage regression. "J-test" is the p-value of Hansen's J-test. Weights from Huber robust regression are applied to reduced the influence of extreme values. Robust standard errors are in parentheses. 
Appendix Table A6. Purified total factor productivity (BFK) and plant days in operation (POD).

\begin{tabular}{|c|c|c|c|c|c|c|c|}
\hline \multirow[b]{2}{*}{ Weight variable } & \multicolumn{2}{|c|}{ Aggregate series } & \multicolumn{2}{|c|}{ Industry series, Pooled } & \multicolumn{3}{|c|}{ Industry series, Fixed effects } \\
\hline & $\begin{array}{c}\text { OLS } \\
(1) \\
\end{array}$ & $\begin{array}{l}\text { IV } \\
(2) \\
\end{array}$ & $\begin{array}{c}\text { OLS } \\
(3) \\
\end{array}$ & $\begin{array}{l}\text { IV } \\
(4) \\
\end{array}$ & $\begin{array}{c}\text { OLS } \\
(5) \\
\end{array}$ & $\begin{array}{c}\text { OLS w/ year } \\
\text { effects } \\
(6) \\
\end{array}$ & $\begin{array}{l}\text { IV } \\
(7) \\
\end{array}$ \\
\hline Weighted by capital stock & $\begin{array}{c}-0.562 * * * \\
(0.174)\end{array}$ & $\begin{array}{l}-0.769 \\
(0.874)\end{array}$ & $\begin{array}{c}-0.186 * * * \\
(0.053)\end{array}$ & $\begin{array}{c}0.159 \\
(0.393)\end{array}$ & $\begin{array}{c}-0.185^{* * *} * \\
(0.054)\end{array}$ & $\begin{array}{c}-0.144 * * \\
(0.060)\end{array}$ & $\begin{array}{c}0.163 \\
(0.395)\end{array}$ \\
\hline Observations & 27 & 27 & 561 & 561 & 561 & 561 & 561 \\
\hline R-squared & 0.193 & 0.167 & 0.024 & -0.059 & 0.038 & 0.185 & -0.046 \\
\hline 1st F-stat & & 0.732 & & 3.545 & & & 3.505 \\
\hline J-test & & 0.17 & & 0.172 & & & 0.199 \\
\hline Simple average & $\begin{array}{l}-0.223 \\
(0.294)\end{array}$ & $\begin{array}{c}-4.159 \\
(11.181)\end{array}$ & $\begin{array}{l}-0.063 \\
(0.039)\end{array}$ & $\begin{array}{l}-2.036 \\
(3.242)\end{array}$ & $\begin{array}{c}-0.06 \\
(0.040)\end{array}$ & $\begin{array}{c}-0.044 \\
(0.041)\end{array}$ & $\begin{array}{l}-2.054 \\
(3.564)\end{array}$ \\
\hline Observations & 27 & 27 & 561 & 561 & 561 & 561 & 561 \\
\hline R-squared & 0.02 & -6.081 & 0.005 & -4.489 & 0.019 & 0.174 & -4.533 \\
\hline 1st F-stat & & 0.977 & & 0.191 & & & 3.129 \\
\hline J-test & & 0.0618 & & 0.954 & & & 0.000 \\
\hline Weighted by output & $\begin{array}{c}-0.648 * * * \\
(0.209)\end{array}$ & $\begin{array}{l}-1.038 \\
(1.308)\end{array}$ & $\begin{array}{c}-0.128 * * \\
(0.059)\end{array}$ & $\begin{array}{c}0.46 \\
(0.603)\end{array}$ & $\begin{array}{c}-0.127 * * \\
(0.061)\end{array}$ & $\begin{array}{l}-0.079 \\
(0.071)\end{array}$ & $\begin{array}{c}0.446 \\
(0.603)\end{array}$ \\
\hline Observations & 27 & 27 & 561 & 561 & 561 & 561 & 561 \\
\hline R-squared & 0.172 & 0.109 & 0.01 & -0.194 & 0.023 & 0.175 & -0.17 \\
\hline 1st F-stat & & 0.366 & & 2.22 & & & 2.158 \\
\hline J-test & & 0.19 & & 0.294 & & & 0.319 \\
\hline Weighted by employment & $\begin{array}{c}-0.472 * * \\
(0.214)\end{array}$ & $\begin{array}{c}0.844 \\
(1.749)\end{array}$ & $\begin{array}{c}-0.143 * * \\
(0.061)\end{array}$ & $\begin{array}{c}0.395 \\
(0.553)\end{array}$ & $\begin{array}{c}-0.143 * * \\
(0.062)\end{array}$ & $\begin{array}{c}-0.092 \\
(0.074)\end{array}$ & $\begin{array}{c}0.381 \\
(0.555)\end{array}$ \\
\hline Observations & 27 & 27 & 561 & 561 & 561 & 561 & 561 \\
\hline R-squared & 0.098 & -0.663 & 0.011 & -0.148 & 0.025 & 0.176 & -0.126 \\
\hline 1st F-stat & & 0.471 & & 2.77 & & & 2.7 \\
\hline J-test & & 0.589 & & 0.263 & & & 0.286 \\
\hline
\end{tabular}

Notes: Dependent variable is the TFP measure from NBER productivity dataset (Bartelsman et al., 2000). Regression specification is given by equation (9). IV includes two instrumental variables as in Basu et al. (2006): monetary policy shocks, oil price shocks. " $1{ }^{\text {st }}$ F-stat" is the F-statistic from the first stage regression. "J-test" is the p-value of Hansen's J-test. Weights from Huber robust regression are applied to reduced the influence of extreme values. Robust standard errors are in parentheses. 
Appendix Table A7. Total factor productivity and plant hours per day (PHD) by industry.

\begin{tabular}{|c|c|c|c|c|c|c|}
\hline \multirow[b]{2}{*}{ Industry } & \multicolumn{2}{|c|}{ BBG TFP } & \multicolumn{2}{|c|}{ BFK TFP } & \multicolumn{2}{|c|}{ purified BFK TFP } \\
\hline & $\begin{array}{l}\text { OLS } \\
(1)\end{array}$ & $\begin{array}{l}\text { IV } \\
(2)\end{array}$ & $\begin{array}{l}\text { OLS } \\
(3)\end{array}$ & $\begin{array}{l}\text { IV } \\
(4)\end{array}$ & $\begin{array}{l}\text { OLS } \\
(5)\end{array}$ & $\begin{array}{l}\text { IV } \\
\text { (6) }\end{array}$ \\
\hline 20 & $\begin{array}{l}-0.153 \\
(0.174)\end{array}$ & $\begin{array}{c}-0.902 \\
(1.670)\end{array}$ & $\begin{array}{l}-0.043 \\
(0.171)\end{array}$ & $\begin{array}{l}-1.244 \\
(2.613)\end{array}$ & $\begin{array}{l}-0.005 \\
(0.188)\end{array}$ & $\begin{array}{c}1.036 \\
(3.168)\end{array}$ \\
\hline 21 & $\begin{array}{c}0.077 \\
(0.097)\end{array}$ & $\begin{array}{l}-0.037 \\
(0.188)\end{array}$ & $\begin{array}{l}0.079^{*} \\
(0.042)\end{array}$ & $\begin{array}{c}0.062 \\
(0.114)\end{array}$ & $\begin{array}{l}-0.085 \\
(0.094)\end{array}$ & $\begin{array}{l}-0.192 \\
(0.180)\end{array}$ \\
\hline 22 & $\begin{array}{c}0.399 * * * \\
(0.111)\end{array}$ & $\begin{array}{l}-0.019 \\
(0.552)\end{array}$ & $\begin{array}{c}0.193 \\
(0.177)\end{array}$ & $\begin{array}{l}-0.346 \\
(0.598)\end{array}$ & $\begin{array}{l}-0.171 \\
(0.242)\end{array}$ & $\begin{array}{c}0.372 \\
(0.723)\end{array}$ \\
\hline 23 & $\begin{array}{c}-0.038 \\
(0.060)\end{array}$ & $\begin{array}{l}-0.157 * \\
(0.094)\end{array}$ & $\begin{array}{l}-0.016 \\
(0.039)\end{array}$ & $\begin{array}{c}0.012 \\
(0.115)\end{array}$ & $\begin{array}{c}0.058 \\
(0.064)\end{array}$ & $\begin{array}{l}-0.109 \\
(0.324)\end{array}$ \\
\hline 24 & $\begin{array}{c}-0.014 \\
(0.105)\end{array}$ & $\begin{array}{c}0.116 \\
(0.209)\end{array}$ & $\begin{array}{c}-0.047 \\
(0.135)\end{array}$ & $\begin{array}{c}0.074 \\
(0.173)\end{array}$ & $\begin{array}{c}0.088 \\
(0.142)\end{array}$ & $\begin{array}{c}0.155 \\
(0.180)\end{array}$ \\
\hline 25 & $\begin{array}{c}0.247 * * * \\
(0.078)\end{array}$ & $\begin{array}{c}0.087 \\
(0.163)\end{array}$ & $\begin{array}{c}0.154 * * * \\
(0.052)\end{array}$ & $\begin{array}{c}0.128 \\
(0.328)\end{array}$ & $\begin{array}{c}0.062 \\
(0.070)\end{array}$ & $\begin{array}{l}-0.003 \\
(0.310)\end{array}$ \\
\hline 26 & $\begin{array}{c}0.210 \\
(0.254)\end{array}$ & $\begin{array}{c}0.165 \\
(1.844)\end{array}$ & $\begin{array}{c}-0.735^{* * *} \\
(0.326)\end{array}$ & $\begin{array}{c}1.338 \\
(1.931)\end{array}$ & $\begin{array}{l}-0.043 \\
(0.290)\end{array}$ & $\begin{array}{c}1.018 \\
(3.033)\end{array}$ \\
\hline 27 & $\begin{array}{c}-0.038 \\
(0.126)\end{array}$ & $\begin{array}{l}-1.021 \\
(1.649)\end{array}$ & $\begin{array}{c}0.057 \\
(0.116)\end{array}$ & $\begin{array}{c}-0.784 \\
(1.016)\end{array}$ & $\begin{array}{c}0.069 \\
(0.127)\end{array}$ & $\begin{array}{l}-0.596 \\
(0.915)\end{array}$ \\
\hline 28 & $\begin{array}{c}0.108 \\
(0.241)\end{array}$ & $\begin{array}{l}-0.532 \\
(0.789)\end{array}$ & $\begin{array}{c}0.088 \\
(0.100)\end{array}$ & $\begin{array}{c}0.302 \\
(0.639)\end{array}$ & $\begin{array}{l}-0.090 \\
(0.140)\end{array}$ & $\begin{array}{c}0.260 \\
(0.601)\end{array}$ \\
\hline 29 & $\begin{array}{c}0.690 * * * \\
(0.183)\end{array}$ & $\begin{array}{c}0.384 \\
(0.615)\end{array}$ & $\begin{array}{c}0.283 * * * \\
(0.099)\end{array}$ & $\begin{array}{c}0.880 \\
(0.609)\end{array}$ & $\begin{array}{l}-0.075 \\
(0.191)\end{array}$ & $\begin{array}{c}1.255 \\
(1.257)\end{array}$ \\
\hline 30 & $\begin{array}{c}0.353 * * * \\
(0.122)\end{array}$ & $\begin{array}{c}0.196 \\
(0.384)\end{array}$ & $\begin{array}{c}0.125 \\
(0.157)\end{array}$ & $\begin{array}{l}-0.099 \\
(0.285)\end{array}$ & $\begin{array}{l}-0.130 \\
(0.111)\end{array}$ & $\begin{array}{l}-0.329 \\
(0.345)\end{array}$ \\
\hline 31 & $\begin{array}{c}-0.029 \\
(0.046)\end{array}$ & $\begin{array}{l}-0.051 \\
(0.112)\end{array}$ & $\begin{array}{c}0.016 \\
(0.055)\end{array}$ & $\begin{array}{c}0.063 \\
(0.117)\end{array}$ & $\begin{array}{c}0.008 \\
(0.062)\end{array}$ & $\begin{array}{c}0.139 \\
(0.187)\end{array}$ \\
\hline 32 & $\begin{array}{l}-0.211^{*} \\
(0.110)\end{array}$ & $\begin{array}{c}0.604 \\
(0.564)\end{array}$ & $\begin{array}{c}-0.207 * * * \\
(0.075)\end{array}$ & $\begin{array}{l}-0.176 \\
(0.287)\end{array}$ & $\begin{array}{c}-0.218 * * \\
(0.100)\end{array}$ & $\begin{array}{l}-0.540 \\
(0.422)\end{array}$ \\
\hline 33 & $\begin{array}{c}0.194 * * \\
(0.082)\end{array}$ & $\begin{array}{l}0.324 * \\
(0.174)\end{array}$ & $\begin{array}{l}-0.033 \\
(0.061)\end{array}$ & $\begin{array}{c}0.014 \\
(0.163)\end{array}$ & $\begin{array}{c}-0.130^{*} \\
(0.076)\end{array}$ & $\begin{array}{c}0.038 \\
(0.275)\end{array}$ \\
\hline 34 & $\begin{array}{c}0.266^{* *} \\
(0.104)\end{array}$ & $\begin{array}{c}0.096 \\
(0.234)\end{array}$ & $\begin{array}{c}0.133 \\
(0.095)\end{array}$ & $\begin{array}{l}-0.016 \\
(0.198)\end{array}$ & $\begin{array}{c}-0.285^{* *} \\
(0.131)\end{array}$ & $\begin{array}{l}-0.239 \\
(0.187)\end{array}$ \\
\hline 35 & $\begin{array}{c}0.515 * * * \\
(0.081)\end{array}$ & $\begin{array}{c}0.337 \\
(0.218)\end{array}$ & $\begin{array}{c}0.404 * * * \\
(0.111)\end{array}$ & $\begin{array}{l}0.347^{*} \\
(0.178)\end{array}$ & $\begin{array}{l}-0.113 \\
(0.123)\end{array}$ & $\begin{array}{c}0.103 \\
(0.200)\end{array}$ \\
\hline 36 & $\begin{array}{c}0.308 * * * \\
(0.106)\end{array}$ & $\begin{array}{c}0.425^{* *} \\
(0.182)\end{array}$ & $\begin{array}{c}0.161 \\
(0.099)\end{array}$ & $\begin{array}{c}0.808 \\
(0.632)\end{array}$ & $\begin{array}{l}-0.137 \\
(0.089)\end{array}$ & $\begin{array}{c}0.502 \\
(0.601)\end{array}$ \\
\hline 38 & $\begin{array}{c}0.135^{* *} \\
(0.056)\end{array}$ & $\begin{array}{l}-0.003 \\
(0.121)\end{array}$ & $\begin{array}{l}0.176^{*} \\
(0.103)\end{array}$ & $\begin{array}{l}0.516^{*} \\
(0.290)\end{array}$ & $\begin{array}{c}0.256^{* * *} * \\
(0.079)\end{array}$ & $\begin{array}{l}0.423^{*} \\
(0.242)\end{array}$ \\
\hline 39 & $\begin{array}{l}-0.052 \\
(0.083)\end{array}$ & $\begin{array}{l}-0.403 \\
(0.288)\end{array}$ & $\begin{array}{c}-0.167 * * \\
(0.080)\end{array}$ & $\begin{array}{c}0.024 \\
(0.231)\end{array}$ & $\begin{array}{l}-0.175^{*} \\
(0.100)\end{array}$ & $\begin{array}{c}0.043 \\
(0.316)\end{array}$ \\
\hline 371 & $\begin{array}{c}0.446 * * * \\
(0.083)\end{array}$ & $\begin{array}{c}0.342 * * \\
(0.149)\end{array}$ & $\begin{array}{c}0.169 * * * \\
(0.055)\end{array}$ & $\begin{array}{c}0.123 \\
(0.092)\end{array}$ & $\begin{array}{l}-0.058 \\
(0.065)\end{array}$ & $\begin{array}{l}-0.092 \\
(0.091)\end{array}$ \\
\hline $372-379$ & $\begin{array}{c}0.011 \\
(0.083)\end{array}$ & $\begin{array}{c}0.497 \\
(0.540)\end{array}$ & $\begin{array}{c}0.145 \\
(0.098)\end{array}$ & $\begin{array}{c}0.341 \\
(0.455)\end{array}$ & $\begin{array}{c}0.141 \\
(0.113)\end{array}$ & $\begin{array}{c}0.430 \\
(0.446)\end{array}$ \\
\hline cont. process industries & $\begin{array}{c}0.090^{* * * *} \\
(0.027)\end{array}$ & $\begin{array}{c}0.532 \\
(0.510)\end{array}$ & $\begin{array}{c}0.061 * * \\
(0.025)\end{array}$ & $\begin{array}{l}-0.280 \\
(0.455)\end{array}$ & $\begin{array}{c}0.168^{* * *} \\
(0.053)\end{array}$ & $\begin{array}{c}0.267 \\
(0.409)\end{array}$ \\
\hline non-cont. process industries & $\begin{array}{c}0.176^{* *} \\
(0.085)\end{array}$ & $\begin{array}{l}-2.347 \\
(3.209)\end{array}$ & $\begin{array}{c}0.020 \\
(0.068)\end{array}$ & $\begin{array}{c}2.381 \\
(2.898)\end{array}$ & $\begin{array}{c}-0.259 * * * \\
(0.082)\end{array}$ & $\begin{array}{l}-1.577 \\
(1.241)\end{array}$ \\
\hline Observations & 520 & 520 & 562 & 562 & 561 & 561 \\
\hline
\end{tabular}

Notes: BFK TFP and purified BFK TFP are productivity measure from Basu et al. (2006). BBG TFP is the productivity measure from NBER productivity dataset (Bartelsman et al., 2000). Regression specification is given by equation (9). IV includes two instrumental variables as in Basu et al. (2006): monetary policy shocks, oil price shocks. " $1^{\text {st }}$ F-stat" is the F-statistic from the first stage regression. "J-test" is the p-value of Hansen's J-test. Weights from Huber robust regression are applied to reduced the influence of extreme values. Robust standard errors are in parentheses. *, $* *$, and $* * *$ are significant at $10 \%, 5 \%$, and $1 \%$ respectively. 
Appendix Table A8. Total factor productivity and plant days in operation per week (POD) by industry.

\begin{tabular}{|c|c|c|c|c|c|c|}
\hline \multirow[b]{2}{*}{ Industry } & \multicolumn{2}{|c|}{ BBG TFP } & \multicolumn{2}{|c|}{ BFK TFP } & \multicolumn{2}{|c|}{ purified BFK TFP } \\
\hline & $\begin{array}{l}\text { OLS } \\
(1)\end{array}$ & $\begin{array}{l}\text { IV } \\
\text { (2) }\end{array}$ & $\begin{array}{l}\text { OLS } \\
\text { (3) }\end{array}$ & $\begin{array}{l}\text { IV } \\
\text { (4) }\end{array}$ & $\begin{array}{l}\text { OLS } \\
(5)\end{array}$ & $\begin{array}{l}\text { IV } \\
(6)\end{array}$ \\
\hline 20 & $\begin{array}{c}-0.288 \\
(0.354)\end{array}$ & $\begin{array}{l}-1.409 \\
(2.990)\end{array}$ & $\begin{array}{l}-0.171 \\
(0.364)\end{array}$ & $\begin{array}{c}2.794 \\
(3.308)\end{array}$ & $\begin{array}{l}-0.296 \\
(0.498)\end{array}$ & $\begin{array}{c}3.963 \\
(4.787)\end{array}$ \\
\hline 21 & $\begin{array}{c}0.589 * * * \\
(0.162)\end{array}$ & $\begin{array}{c}1.029 \\
(1.745)\end{array}$ & $\begin{array}{c}0.583 * * * \\
(0.154)\end{array}$ & $\begin{array}{c}0.822 \\
(0.578)\end{array}$ & $\begin{array}{c}-0.721 * * * \\
(0.152)\end{array}$ & $\begin{array}{l}-1.757 \\
(3.300)\end{array}$ \\
\hline 22 & $\begin{array}{c}0.353 * * * \\
(0.113)\end{array}$ & $\begin{array}{l}-0.135 \\
(0.660)\end{array}$ & $\begin{array}{l}0.209^{*} \\
(0.118)\end{array}$ & $\begin{array}{l}-0.112 \\
(0.677)\end{array}$ & $\begin{array}{l}-0.112 \\
(0.186)\end{array}$ & $\begin{array}{l}-0.427 \\
(0.966)\end{array}$ \\
\hline 23 & $\begin{array}{c}-0.050 \\
(0.221)\end{array}$ & $\begin{array}{c}0.297 \\
(0.521)\end{array}$ & $\begin{array}{c}0.101 \\
(0.138)\end{array}$ & $\begin{array}{c}0.270 \\
(0.343)\end{array}$ & $\begin{array}{l}-0.394 \\
(0.254)\end{array}$ & $\begin{array}{l}-0.438 \\
(0.784)\end{array}$ \\
\hline 24 & $\begin{array}{c}0.132 \\
(0.160)\end{array}$ & $\begin{array}{l}-0.012 \\
(0.655)\end{array}$ & $\begin{array}{c}0.536^{* *} \\
(0.226)\end{array}$ & $\begin{array}{c}0.220 \\
(0.925)\end{array}$ & $\begin{array}{c}0.328 \\
(0.202)\end{array}$ & $\begin{array}{c}0.197 \\
(0.767)\end{array}$ \\
\hline 25 & $\begin{array}{c}0.629 * * * \\
(0.192)\end{array}$ & $\begin{array}{l}-0.656 \\
(3.062)\end{array}$ & $\begin{array}{c}0.415 * * * \\
(0.112)\end{array}$ & $\begin{array}{l}-0.372 \\
(2.279)\end{array}$ & $\begin{array}{l}-0.006 \\
(0.235)\end{array}$ & $\begin{array}{l}-0.321 \\
(1.870)\end{array}$ \\
\hline 26 & $\begin{array}{c}0.114 \\
(0.397)\end{array}$ & $\begin{array}{c}1.211 \\
(1.472)\end{array}$ & $\begin{array}{c}-0.346 \\
(0.487)\end{array}$ & $\begin{array}{c}1.554 \\
(1.636)\end{array}$ & $\begin{array}{c}0.115 \\
(0.391)\end{array}$ & $\begin{array}{c}2.556 \\
(5.816)\end{array}$ \\
\hline 27 & $\begin{array}{l}-0.180 \\
(0.216)\end{array}$ & $\begin{array}{c}0.513 \\
(0.793)\end{array}$ & $\begin{array}{c}-0.191 * \\
(0.105)\end{array}$ & $\begin{array}{l}-0.658 \\
(0.748)\end{array}$ & $\begin{array}{c}0.067 \\
(0.173)\end{array}$ & $\begin{array}{c}-0.444 \\
(1.031)\end{array}$ \\
\hline 28 & $\begin{array}{c}-0.715^{* * *} \\
(0.195)\end{array}$ & $\begin{array}{l}-1.027 \\
(0.868)\end{array}$ & $\begin{array}{c}-0.893 * * \\
(0.357)\end{array}$ & $\begin{array}{l}-0.437 \\
(1.011)\end{array}$ & $\begin{array}{l}-0.369 \\
(0.235)\end{array}$ & $\begin{array}{c}0.169 \\
(1.052)\end{array}$ \\
\hline 29 & $\begin{array}{c}0.783 * * \\
(0.368)\end{array}$ & $\begin{array}{l}-0.400 \\
(1.321)\end{array}$ & $\begin{array}{c}0.216 \\
(0.134)\end{array}$ & $\begin{array}{l}-0.665 \\
(1.700)\end{array}$ & $\begin{array}{c}-0.537 * * * \\
(0.145)\end{array}$ & $\begin{array}{c}-2.178^{* *} \\
(1.030)\end{array}$ \\
\hline 30 & $\begin{array}{c}0.768 * * * \\
(0.152)\end{array}$ & $\begin{array}{c}0.258 \\
(0.454)\end{array}$ & $\begin{array}{c}0.122 \\
(0.129)\end{array}$ & $\begin{array}{c}0.233 \\
(0.356)\end{array}$ & $\begin{array}{l}-0.173 \\
(0.149)\end{array}$ & $\begin{array}{c}0.213 \\
(0.322)\end{array}$ \\
\hline 31 & $\begin{array}{c}0.119 \\
(0.244)\end{array}$ & $\begin{array}{l}-0.801 \\
(1.597)\end{array}$ & $\begin{array}{c}0.325^{* *} \\
(0.148)\end{array}$ & $\begin{array}{c}0.160 \\
(0.547)\end{array}$ & $\begin{array}{c}0.242 \\
(0.172)\end{array}$ & $\begin{array}{c}0.992 \\
(1.863)\end{array}$ \\
\hline 32 & $\begin{array}{l}-0.298 \\
(0.343)\end{array}$ & $\begin{array}{l}2.037 \\
(2.770)\end{array}$ & $\begin{array}{c}-0.318 \\
(0.211)\end{array}$ & $\begin{array}{c}0.118 \\
(1.097)\end{array}$ & $\begin{array}{l}-0.246 \\
(0.182)\end{array}$ & $\begin{array}{c}-0.402 \\
(1.091)\end{array}$ \\
\hline 33 & $\begin{array}{c}0.228 * * \\
(0.092)\end{array}$ & $\begin{array}{l}0.458^{*} \\
(0.274)\end{array}$ & $\begin{array}{c}-0.143 * * \\
(0.069)\end{array}$ & $\begin{array}{l}-0.031 \\
(0.184)\end{array}$ & $\begin{array}{c}-0.246 * * \\
(0.102)\end{array}$ & $\begin{array}{c}0.027 \\
(0.344)\end{array}$ \\
\hline 34 & $\begin{array}{c}1.059 * * * \\
(0.285)\end{array}$ & $\begin{array}{c}0.241 \\
(0.976)\end{array}$ & $\begin{array}{c}0.398 \\
(0.253)\end{array}$ & $\begin{array}{l}-0.071 \\
(0.837)\end{array}$ & $\begin{array}{c}-0.651^{* * *} \\
(0.259)\end{array}$ & $\begin{array}{l}-0.072 \\
(0.721)\end{array}$ \\
\hline 35 & $\begin{array}{c}1.226 * * * \\
(0.325)\end{array}$ & $\begin{array}{c}0.839 \\
(0.888)\end{array}$ & $\begin{array}{c}0.813^{* *} \\
(0.380)\end{array}$ & $\begin{array}{c}1.243 \\
(0.904)\end{array}$ & $\begin{array}{l}-0.355 \\
(0.308)\end{array}$ & $\begin{array}{c}0.451 \\
(1.051)\end{array}$ \\
\hline 36 & $\begin{array}{c}0.539^{* *} \\
(0.234)\end{array}$ & $\begin{array}{l}1.513^{*} \\
(0.867)\end{array}$ & $\begin{array}{l}-0.118 \\
(0.201)\end{array}$ & $\begin{array}{c}8.151 \\
(33.853)\end{array}$ & $\begin{array}{c}-0.519 * * * \\
(0.197)\end{array}$ & $\begin{array}{c}2.827 \\
(6.871)\end{array}$ \\
\hline 38 & $\begin{array}{c}0.949 * * * \\
(0.270)\end{array}$ & $\begin{array}{c}0.043 \\
(1.983)\end{array}$ & $\begin{array}{l}-0.229 \\
(0.238)\end{array}$ & $\begin{array}{c}6.139 \\
(7.024)\end{array}$ & $\begin{array}{l}-0.111 \\
(0.284)\end{array}$ & $\begin{array}{c}4.614 \\
(5.249)\end{array}$ \\
\hline 39 & $\begin{array}{c}0.389 \\
(0.333)\end{array}$ & $\begin{array}{c}0.109 \\
(1.737)\end{array}$ & $\begin{array}{c}0.033 \\
(0.240)\end{array}$ & $\begin{array}{c}0.406 \\
(1.420)\end{array}$ & $\begin{array}{l}-0.144 \\
(0.257)\end{array}$ & $\begin{array}{c}1.207 \\
(2.214)\end{array}$ \\
\hline 371 & $\begin{array}{c}0.523 * * * \\
(0.202)\end{array}$ & $\begin{array}{l}0.539^{*} \\
(0.284)\end{array}$ & $\begin{array}{c}0.232 * * \\
(0.117)\end{array}$ & $\begin{array}{c}0.132 \\
(0.226)\end{array}$ & $\begin{array}{l}-0.124 \\
(0.182)\end{array}$ & $\begin{array}{l}-0.238 \\
(0.169)\end{array}$ \\
\hline $372-379$ & $\begin{array}{c}0.128 \\
(0.334)\end{array}$ & $\begin{array}{l}-2.321 \\
(4.106)\end{array}$ & $\begin{array}{c}0.126 \\
(0.261)\end{array}$ & $\begin{array}{l}-3.662 \\
(5.926)\end{array}$ & $\begin{array}{c}0.572 * * \\
(0.254)\end{array}$ & $\begin{array}{l}-3.293 \\
(6.331)\end{array}$ \\
\hline cont. process industries & $\begin{array}{c}0.360 * * * \\
(0.065)\end{array}$ & $\begin{array}{l}0.513^{*} \\
(0.307)\end{array}$ & $\begin{array}{c}0.168 * * * \\
(0.053)\end{array}$ & $\begin{array}{c}0.267 \\
(0.409)\end{array}$ & $\begin{array}{c}-0.132 * * \\
(0.063)\end{array}$ & $\begin{array}{c}0.293 \\
(0.426)\end{array}$ \\
\hline non-cont. process industries & $\begin{array}{c}-0.182^{*} \\
(0.109)\end{array}$ & $\begin{array}{l}-1.074 \\
(1.029)\end{array}$ & $\begin{array}{c}-0.259 * * * \\
(0.082)\end{array}$ & $\begin{array}{l}-1.577 \\
(1.241)\end{array}$ & $\begin{array}{l}-0.138 \\
(0.113)\end{array}$ & $\begin{array}{l}-2.210 \\
(1.520)\end{array}$ \\
\hline Observations & 521 & 521 & 561 & 561 & 561 & 561 \\
\hline
\end{tabular}

Notes: BFK TFP and purified BFK TFP are productivity measure from Basu et al. (2006). BBG TFP is the productivity measure from NBER productivity dataset (Bartelsman et al., 2000). Regression specification is given by equation (9). IV includes two instrumental variables as in Basu et al. (2006): monetary policy shocks, oil price shocks. " 1 st F-stat" is the F-statistic from the first stage regression. "J-test" is the p-value of Hansen's J-test. Weights from Huber robust regression are applied to reduced the influence of extreme values. Robust standard errors are in parentheses. *, $* *$, and $* * *$ are significant at $10 \%, 5 \%$, and $1 \%$ respectively. 


\section{Appendix B: Construction of capital stock.}

One of the basic measures of capital stock used in our analysis is the historical cost of structures (BAE) and machines/equipment (MAE) reported by establishments. The advantage of this measure is that it is readily available for reporting by firms and it is strongly correlated with measures of real capital stock constructed using perpetual inventory methods. In additional, this variable has been cleaned and hence is particularly useful in our analyses.

The main issue is that the overlap between SPC and ASM has been declining in recent years. Specifically, SPC no longer samples from ASM. Instead SPC sample firms from CM and firms which are not considered a part of manufacturing. Since for many firms capital stock is a slow moving variable we focus on the capital stock (historical cost) reported in the Census years. In other words, for a firm in SPC 1994 we use the capital stock this firm reported in 1992 Economic Census.

We created measures of real capital stock based on perpetual inventory. When we construct real capital stock we use perpetual inventory separately for equipment and structures:

$$
K_{t+1}=(1-\delta) K_{t}+I_{t} / P I_{t}
$$

where $\mathrm{K}$ is capital stock, $\mathrm{I}$ is nominal investment, $\mathrm{PI}$ is the price index for investment goods. ${ }^{18}$ The price deflators for investment in new and used capital are from NBER productivity dataset. This dataset in turn is based on the data from BEA. The NBER productivity data set is at 4-digit SIC level. 2-digit SIC industry depreciation rates are from BEA. ${ }^{19}$

To start the perpetual inventory, we set the initial capital stock equal to the historical cost of capital in this firm times the ratio of replacement value of capital to historical value of capital in the industry to which the given firm belongs. If the firm does not report the initial historical stock of capital (it happens mainly in later years when BAE and MAE were collected only in Census year), we impute the real capital stock based on a regression of historical cost of capital

\footnotetext{
${ }^{18}$ In earlier years ASM/CM collected information on retirements and sales of capital (structures and machines). We do not use this information to adjust our measures of capital because we do not have this information after early 1990s. So we do not take into account disinvestment in our perpetual inventory calculations.

${ }^{19}$ NBER/BLS/BEA data is coded in SIC-1987. This data set has level of real capital stock, labor, materials, output and price indices. The base year in price indices is 1987. The level of disaggregation is 4-digit. The data runs from 1958 to 2002. Data for 2003-2004 is extrapolated using industry-specific AR(1) regression estimated on previous years. We also use BEA data on historical and current value of capital stock (in current and fixed 1996 dollars) and depreciation rates by industries. The data runs from 1972 to 2002. Data for 2003-2004 is extrapolated using projection on the constant and time trend. This regression is estimated industry-by-industry on last 10 years of the data.
} 
on polynomials of investment, sales and employment. These regressions have all variables in logs, have year fixed effects and are industry and type-of-capital specific. In other words, for each industry and separately for structures and machines, we regress real capital stock on polynomials of sales and employment (incl. year fixed effects) and then take predicted values from this regressions as initial values for perpetual inventory. When firms report only $\mathrm{BAE}+\mathrm{MAE}$, we use historical average in the industry for the share of structures in total capital stock to split BAE+MAE into BAE and MAE. ${ }^{20}$

Because ASM and SPC change the sample of firms every five years, we have firms with 5-year gaps in reporting of investment. ASM and SPC also add firms to the sample to compensate for attrition of the sample. For these types of firms, we have gaps in reported investment. We impute investment using several methods: i) industry median (conditional on positive investment), ii) regression based, iii) zero investment. In the first approach, we use the historical probability of making a positive investment to determine whether a firm makes an investment. ${ }^{21}$ In the second approach, we use tobit-type regression where explanatory variables are polynomials in sales and employment. In the third approach we set investment equal to zero if it is missing.

We run perpetual inventory equation (15) forward and backward. The resulting real capital stock is in fixed 1987 dollars.

\footnotetext{
${ }^{20}$ Information on balance sheet value of equipment (structures) was collected annually before 1992 and only in census years afterwards. After 1997, only information on total assets is collected (no split between equipment and structures). Even for census years, only firms with "long forms" report assets.

${ }^{21}$ In other words, we draw a random value from $U[0,1]$ and if the drawn value is greater than some threshold we assign a given firm with a positive investment. If the draw value is below the threshold, we assign zero investment to the firm. Conditional on positive investment, the firm receives the median investment in its 4-digit industry. This approach is aimed at capturing the fact that investment is bunched in spikes.
} 